\title{
The Growth of the City State: Lectures on Greek and Roman History.
}

\section{William Reginald Halliday. B.A., B.LITT.}

Rathbone Professor of Ancient History in the University of Liverpool

1923.

Athenian Stranger. Enough of this. And what, then is to be regarded as the origin of government? Will not a man be able to judge best from a point of view in which he may behold the progress of states and their transitions to good or evil?

Cleinias... What do you mean?

Athenian Stranger. I mean that he might watch them from the point of view of time, and observe the changes which take place in them during infinite ages.

Plato, Laws, III, 676.

\section{Batoche Books}

Kitchener 
Batoche Books

Kitchener, Ontario

Canada

email: batoche@gto.net 


\section{Table of Contents}

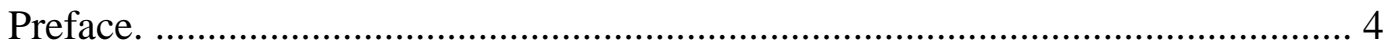

Lecture I. Geographical Influences. The Migrations of Peoples. ......................... 7

Lecture II. Geographical Influences: The Greeks and the Sea. ........................... 17

Lecture III. Geographical Influences: The Western Mediterranean. .................... 33

Lecture IV. The Growth of the City State. ...................................................... 49

Lecture V. The Early Constitutional Development of Athens. ........................... 80

Lecture VI. The Early Constitutional Development of Rome. ......................... 101

Lecture VII. The Land Question. ............................................................. 129

Lecture VIII. Pheidippides. Social Conditions in Athens in the Fifth Century. 


\section{Preface.}

Perhaps overconfidently I have label led these lectures First Series, but the menace of a further instal ment will not materialise unless the book proves in fact to be of practical use. It may be that it falls between two stools and while too elementary for advanced students it may be too difficult for beginners.

After the war, when the necessity for rubbing up my recollections of elementary facts was urgent and I was re-reading the main classical authorities, I planned a session's course of lectures which should not follow the chronological sequence of events but should aim rather at discussing the history of Greece and Rome under the heading of subjects. The lectures of the first term, which this book roughly represents, I intended to cover the earlier history of the city state; the second term I had meant to devote to the struggle between East and West (i.e., the relations of Greece with Persia and Carthage and those of Rome with Carthage and the Eastern powers) and to the consideration of the classical experiments in government upon a larger scale than the city state. In the last term I intended to discuss the classical states from within, i.e, to examine how Athenian democracy worked, and to consider the reasons for the critical view of democracy with which experience inspired almost all thoughtful Greek writers, and then to discuss the breakdown of the Roman Republic after the Great Wars and the merits of the respective preferences of Cato and the gods.

The plan was a complete failure. My first year pupils, for whom the course was intended, proved to be too ill-prepared to profit by so allusive a treatment. But it is possible that in book form the lectures may be more fortunate. At least there is no harm in putting it to the test.

Two points I should like to emphasise. Firstly that these lectures are intended to be read with or after not instead of the textbook. There is no short cut to learning history, or indeed anything else, and of the two unintelligent processes, which sometimes pass for acquiring knowledge, 


\section{W. R. Halliday, The Growth of the City State, 5}

it is a far greater waste of time to memorise second-hand opinions than to memorise dates. Secondly the opinions which are expressed in this little book are suggestions for consideration. They are there not to be accepted and committed to memory but to be tested and criticised by the student. I have not, of course, stated anything which I believe to be untrue, but a reader who fails to find something with which to disagree will probably have wasted his time.

The number of notes I fear is tiresome, but I could think of no other way of doing what I wanted to do. Their nature is, of course, explanatory and illustrative, not exhaustive, and their object is to tempt students to look up some of the references, if only in translation. If my readers contract the habit of looking up references and trouble, as they should, to read the context, they are likely to learn more about Greece and Rome than they can hope to do from any secondhand historian.

With regard to references, other than those to classical authors, I have tried to use books which for the greater part are, or should be, in any decently equipped school classical library. To one serious inconsistency I must plead guilty viz., the references to Wilamowitz, Aristoteles und Athen, a German book and a difficult German book at that. The temptation was too strong and my debt too great. I should be very unwilling to subscribe to all the views of the great scholar who wrote it, but I do not know a book from which I have learned more about Athens.

I have pilfered freely from well-known translations of classical authors and my equally unacknowl edged debt to my Oxford teachers is great. In particular those who have sat at the feet of Mr. E. M. Walker are likely to recognise that his lectures on the Athenai on Politeia have col oured my view of Athenian constitutional history and more, I expect, than I realise myself is ultimately derived from them.

I regret that Lecture VII was, in fact, written before I had the opportunity of reading Mr. Heitland's extremely careful and judicial study of ancient agriculture, and has ther efore benefited only by certain additions, corrections, and references.

Thelast lecture, which was originally delivered to the Liverpool Branch of the Classical Association, is reprinted from Annals of Archaeol ogy and 


\section{W. R. Halliday, The Growth of the City State, 6}

Anthropol ogy VIII. It aims at presenting a picture of social conditions in Athens at a period slightly earlier than that of Becker's Charikles and whereas the text of Becker is provided by the Orators, mine is Aristophanic. In knowledge and in the amount of information, which it conveys, it does not attempt, of course, to challenge comparison but I hope that it may prove a little more readable. For though at one time or another I have read all of Charikles I am bound to confess that I have never succeeded in reading it through at a sitting.

An obvious criticism will be raised by the absence of maps, which was decided upon only after careful thought. It seemed to me, however, that the addition of line blocks would add little of value for readers who possess atlases or textbooks containing maps. On the other hand to add maps more elaborate than those which are thus easily accessible, would inevitably add to the cost of production and consequently to the price of the book. Rightly or wrongly I decided that this was the more important consideration.

W. R. HALLIDAY. The University, Liverpool. 
Lecture I. Geographical Influences. The Migrations of Peoples.

The science of geography is of the first importance in the study of the history of man, nor does its contribution to the understanding of history end when it has provided charts by which the student may trace the movements of invading armies, or criticise the strategy of opposing generals. For geography is a study not only of the complicated board, upon which the drama of human life is played out, but also of the rules which condition the game. Man like other living things, must adapt himself to his environment or perish. Herehe differs only from the beasts in that his adaptation is not merely passive. I ncreasingly he becomes the master of nature and is able to modify the conditions which she imposes. Tropical medicine, to take a very recent example, has rendered areas suitablefor col onisation in which previously the white man could not live and work. Science indeed has armed man with powerful weapons for the struggle for existence and has to some extent made him the master of his environment, but the further back you trace his history, the more dependent he will be found to be upon conditions which nature imposes.

Consider for a moment the lower races. Their arrested development is dueultimatel y torestricted opportunity and conditions of existencewhich have stunted development, rather than to any original moral or mental difference between their for efathers and the rest of our human ancestors, which has branded them with the curse of Ham. The struggle for mere survival has been too hard for the Esquimo, living precariously on the spoils of his hunting in a country where the development of agriculture is impossible, and dependent for the material of his arts and crafts upon walrus tusks and whale-bone or the rare fortune of a find of drift-wood. Similarly the Australian black-fellow was isolated in an area where the natural conditions of existence were too hard for a start to be made. Man, in fact, cannot develop a civilised existence unless nature helps him by providing the opportunity and the means.

Ancient civilisation centres on the land-locked and almost tideless sea 


\section{W. R. Halliday, The Growth of the City State, 8}

round the shores of which the three great continents of the Old World meet. Man, it is true, has devel oped civilisations of a high order beyond the Mediterranean area but it would seem as though the civilisation, which has its roots in Greek conceptions of independence in life and thought and in Roman ideals of law and government, is destined ultimately to embrace the world. The law of survival conditions all terrestrial things and, in the competition for existence, civilisations and types of organised society equally with species of the animal kingdom are subject to its operation.

The history of civilisation in the Mediterranean begins long before the coming of the Greeks and Romans, and interest in the history of the earlier civilisations is growing with the recent increase of our knowl edge concerning them. It remains, nevertheless, true that European civilisation is rooted in Greece and Rome and except in so far as they exerted an influence upon the devel opment of Greece and Rome, E gypt and Babylon tend to be neglected except by the specialist. For this however there is more justification than is at first sight apparent. It is not because our detailed knowledge of these ancient civilisations is scanty, though it is of very recent acquisition and perhaps not very easily accessible to the general reader. ${ }^{1}$ It is certainly not becausetheir achievements weresmall. It is almost certain that the solar calendar was adopted in E gypt in 4241 B.C.; the age of the pyramids is witness to the early mastery of engineering on a gigantic scale; both in Mesopotamia and in Egypt a wellorganised system of administration and law was devel oped at a very early date; Egypt, Babylon and Crete independently invented a system of phonetic writing. The Greeks themselves were amazed at the vistas of past civilisation which Egyptian records opened, and were inclined if anything to exaggerate their debt to Egyptian discoveries. And yet in spite of all this the ancient civilisations of Egypt and M esopotamia are contributory only, for spirit is more vital than matter, and quality than size. It is a question of values. Egypt and Mesopotamia hardly ventured beyond patient empiricism and technical achievement to the discovery of scientific principles and the disinterested quest of truth for its own sake. ${ }^{2}$ Civilisation, as we know it, was born with the Greeks, whose genius 


\section{W. R. Halliday, The Growth of the City State, 9}

revolutionised man's attitudetotheuniverseand his ideals as regards his relations with his fellow-men. The material achievements of the older empi res assisted this devel opment; but the East, then as later, has been a contributor only to European civilisation, nor has it ever dominated, profoundly as it may have modified, its progress.

A glance at the map will explain why civilisation earliest developed in Egypt and Babylon upon the banks of the great rivers. In the fertile soil brought down by the Nile and by the great rivers of Mesopotamia corn was early domesticated and man adopted a settled life. The annual inundations of the Nile and the facilities for Mesopotamian irrigation assisted the devel opment of agriculture and prosperity. The Nile valley defended by a barrier of desert enjoyed the advantage of comparative security from foreign intrusion and if Babylonia was more susceptible to the inroads of alien peoples, Semites from the Arabian desert or mountaineers from the North and East, the intrusive elements but supplied new vigour to a civilisation which they conquered but did not destroy.

Between these two great riparian civilisations communication is either by the caravans of the desert tribes or along what Professor Breasted has called "The Fertile Crescent," i.e, through Syria and down the narrow strip between the sea and the sand, which is known as Palestine, to the eastern gate of Egypt. Al ong this route armies, which are unable for lack of water and commissariat to traverse thealternative desert paths of the caravan, no less than trade, can pass. These facts explain the political history of the J ews. Although under the able founders of the kingdom, Saul, David and Solomon, they succeeded in exploiting their opposition on the channel of trade, and attained a wealth and importance out of proportion to their size, their prosperity proved temporary only. For geography has marked out Palestine as the natural battlefield for the nations of the East, and the material fate of its inhabitants is inevitably at the mercy of the large battalions of its greater neighbours. In some respects the case of the J ews is analogous to that of the Asia Minor Greeks, who flourished, commercially through their control of the terminal harbours of the trade routes between Europe and the East, but 


\section{W. R. Halliday, The Growth of the City State, 10}

politically were at the mercy of the power controlling the hinterland.

Of the great civilisations which flourished in the Eastern Mediterranean before the coming of the Greeks, two further powers call for mention. The great bastion of Asia Minor which forms a land-bridge between Europe and the East, was held by the Hittites, whose importance appears to lie rather in their position as intermediaries between East and West than in any original contribution which they made to the civilisation of either. When the history of Greece begins their power was breaking up. On the east it was being absorbed by Assyria, and on the west it was feeling the effects of those migrations of European peoples which, still further west, were overwhelming the Minoan civilisation. The latter is of great importance. The discovery of its existence is recent nor can its documents be read as yet, but the spade has revealed the general outlines of its development.

When the shores and islands of the Mediterranean took their present shape after the last ice age, they were settled by a race of Iongheaded, dark-skinned men, probably of African origin, who had arrived at the neolithic stage of culture. In the course of many thousands of years these people developed in the Bronze Age an independent and brilliant civilisation. Their progress was stimulated by the development of navigation, and they owed much to contact with Egypt. Much, however, as they learned and imitated from the Egyptians, their art retained its vitality and independence. A noticeable quality is the realism of its artistic presentation of nature. The centre of this civilisation was Crete, which shuts in the southern end of the Aegean Sea and is the terminal point of the line of islands pointing south-east from Greece towards Egypt. Of the relative political importance of the sea-kings of Crete it is difficult to be sure in the absence of written records which can be deciphered, but their commerce, at least, spread over the M editerranean both east and west, and they were the predecessors of the Phoenicians as the Phoenicians were predecessors of the Greeks in the carrying trade of the inland sea.

The civilisation which had its home in Crete seems to have invaded the mainland of Greece in the Third Middle Minoan period (circa 1700-1580 


\section{W. R. Halliday, The Growth of the City State, 11}

B.C.) when, to judge from the contents of the royal "Shaft" graves at Mycenae, Cretan overlords established themselves at Mycenae and Tiryns. From that timeto the cl ose of the BronzeAge Minoan-Mycenaean culture was dominant in the Balkan Peninsula. The empire of Cnossus was at its height roughly between 1700 and 1450 B.C. It was apparently al ready in its decl ine before the iron weapons of invaders from the N orth destroyed the Bronze Age civilisation of the Aegean. The palace of Cnossus was destroyed about 1450 B.C., whether by invasion or by internal political trouble must remain doubtful. But since civilisation in Crete, though it degenerated, did not change its character as a result of the fall of Cnossus, it must be assumed that there was no intrusion of a new race. It is possible that an invasion of people of the same Aegean stock, who had been pushed out of their homes on the mainland by the Northerners, was responsiblefor the catastrophe. At about the sametime Mycenae was enlarged and rebuilt, and the great fortress, the walls of which stand to-day, was constructed. To this later period belong the "Beehive" tombs, to the earlier the "Shaft" graves.

From very early times there is evidence of a movement southwards of the peoples of Central Europe. In the Eastern Mediterranean they followed naturally the lines of the Balkan Range, which spreads like a great fan pointing south-east. The first waves seem to have passed by preference along the northern shores of the Aegean into Asia. The pressure on the Greek peninsul a becomes felt considerably later but, once begun, it was continuous and increasingly violent. After the downfall of the Cretan empire in the middle of the second millenium, the mainland fortresses of Mycenae and Tiryns held out for a time, but, when the first millenium is reached, the iron weapons of the N ortherners have smashed the civilisation of the Mediterranean Bronze Age. For a period there was chaos in the Levant. Bands of adventurers carving out new kingdoms, and dispossessed peoples searching for new homes, broke up all stable and ordered life on the islands and the coasts. Egypt suffered the ravaging of her shores by pirates, and the coasts of Asia were invaded by wandering chieftains. It is to the later stages of this period that Homer looks back in his traditions of the Trojan war, and to its close belongs the 


\section{W. R. Halliday, The Growth of the City State, 12}

settlement of the Asia Minor coast by the Greeks. This settlement, which was due to a migration of tribes, it is necessary to distinguish from the later process of colonisation. ${ }^{3}$

Gradual ly theferment of theDark Ages subsided and thereemerged the Greeks of history. In origin then, the Greeks were "magnificent mongrels," a mixed race representing thefusion of the northern invaders with the Bronze Age inhabitants of the Aegean area. Further their cultural development was based on the ruins of the civilisation, which had been slowly and painfully built up during the centuries of the BronzeAge. This fact goes far to solve the riddle of the startling suddenness of the emergence of the Greeks as the leaders of civilisation.

The question naturally arises: what was the cause of these migrations of peoples and who were the invading Northerners? To answer these we must turn once more to the map. The area of civilisation which we have been discussing is bordered on the north and south by two great reservoirs of the human race; on the north by the great grassland steppe, which runs continuously for some 3,000 miles from the U pper Danube to Central Asia, and on the south by the smaller crescent of the Arabian desert. Theraces, wholived upon thegrassland, were naturally nomadic, deriving their living from the animals which they had domesticated. The need of pasturing their flocks and herds of necessity conditions their movement and, as the pasture in one place becomes exhausted, they will move on to find another. There is in consequence a constant movement of peoples along the ridge. Again the nomads, who live upon the edge of the grassland, will come into contact with the settled dwellers of the plain and, from the process of barter with the civilisations upon either edge, a portion of the desert peoples may become merchants. By such carriers goods must have passed between Ur of the Chal dees and Egypt, for only the nomad folk know the way and can travel safely in the desert. A portion of the nomads by this process becomethecarriers of foreign trade; they cease to be purely nomadic, and great terminal emporia, like Damascus, grow up at the desert's edge, in which the travelling merchants have their homes. No doubt there must be a continuous process of infiltration as the population of the grassland in this way overflows the 


\section{W. R. Halliday, The Growth of the City State, 13}

rim of the reservoir. But a more violent process becomes periodically operative. The nomads are dependent upon their flocks and these are dependent upon the supply of grass; if the grass dries up they must move to pastures new. From this results the continual shifting of tribes east and west along the lines of steppe. But if, owing to periodical climatic changes the grasslands dry up on an extensive scale and adequate grazing grounds are not to be found, the nomads will be forced to push beyond the limits of their natural home, and the reservoir of desert peoples overflows in a torrential flood.

The importance of this process in the history of western civilisation can hardl y beexagger ated. I $n$ a sensethat history has been a conflict between the Indo-E uropean of the N orth and theSemite of the South, in which the Northerner has proved on the whole victorious. For in the long run it has been the Indo-European element which has directed the course of development, though reflection for a moment upon the historical origin of the dominant religion of western civilisation, will suggest that the contribution of the Semite has been by no means negligible. Four times at least the southern reservoir, the Arabian desert, some 700 miles in length, has overflowed its banks. The first great wandering of the southern nomads imposed Semitic speech upon Babylonia, and led to the creation of the first great Mesopotamian empire by the Semite Sargon of Accad about 2750 B.C. The second at the beginning of the second millenium, brought the Canaanites and Amorites into Palestine and founded the First Dynasty of the city of Babylon; to this migration the story of the wanderings of Abraham belongs. The account given in Genesis of the battle of the four kings against five enables us to date the migration by the mention of Amraphel, king of Shinar, who is to be identified with Khammurabi, the great law-giver of Babylon. The third great wandering, 1500-1400 B.C. brought the Aramaeans into Syria and the I sraelites into Palestine, ${ }^{4}$ and led to the foundation of the kingdom of Damascus. The fourth, in the seventh century after Christ followed the rise of I slam, when the Arabs carried their new faith as far east as the Malay Peninsula, and poured westwards along the southern shore of the Mediterranean into Sicily and Spain, until the torrent was stayed in 


\section{W. R. Halliday, The Growth of the City State, 14}

Southern France at the battle of Poitiers in A.D. 732.

The northern and larger grasslands, like the southern, were peopled by races of a kindred stock whose languages were related to a common parent. To the Semites of the South are opposed the Indo-E uropeans of the N orth. The area of their natural home was larger but they possessed a more rapid mode of transit than the southern nomads, for, from very early times, they had domesticated not only the ox and the sheep but al so the horse. It has been pointed out by Professor Myres that the northern uplands fall into an hour-glass form, the neck narrowing between the forests of the Lower Vol ga and the Caspian desert. There is a corresponding linguistic difference between the eastern groups of Indo-E uropeans (the Aryans who carried Sanskrit into India about 1600 B.C. and the I ranians, who moved into Media and Persia about the same time), and the western group, which descended from the Danube basin upon the Balkan peninsula and through the Iulian Alps into Italy. But the ancestors of Persians, Greeks and Romans were ultimately of kindred stock, speaking dialects of the same language and originally enjoying a similar social organisation.

A word of caution however is necessary. When we speak of these migrations, it must not be thought that invaders merely take the place of a dispossessed people. What happens is analogous rather to a chemical change. In each case the fusi on of invaders with the invaded produces a new race, and though upon one side of their parentage Romans, Greeks, and Persians, have a common origin, other racial elements in their composition are different, and the respective environments, in which the new-born races developed, presented differing needs, the meeting of which produced different results.

Both Semites and I ndo-E uropeans have exercised a vital ising influence upon the peoples they invaded. Both have had the faculty of imposing their language and social organisation upon the societies with which they fused. Physically, indeed, thel ndo-E uropean typetended to die out in the Mediterranean area. The tall fair-haired $\mathrm{N}$ ortherners disappeared after the heroic age, and the Greek of historical times was short, swarthy, and black-haired like his Aegean predecessors. ${ }^{5}$ But, for the history of 


\section{W. R. Halliday, The Growth of the City State, 15}

civilisation, language and social organisation are more important than the physical characteristics of racial type, and in respect of the former the Greeks and Romans owe a common debt to the Indo-E uropeans from the North.

Finally it would be erroneous to think of the invaders who broke up the civilisation of the Bronze Age as savages. It is clear that before they descended upon the Balkan peninsula they had shared in the culture which had devel oped during the Bronze Age in the Danubian basin. They were still, however, in the comparatively primitive state of civilisation

characteristic of an "heroicage"; they werestill organised for a wandering life, and the Homeric kings were tribal leaders and "tamers of horses."

\section{Notes to Lecture I}

1. Here Professor Breasted's admirable little book Ancient Times fills a real need. The long delayed first volume of the CambridgeAncient History is also likely to have appeared by the time this book is published.

2. The patient observations of the stars by the wise men of Babylon and the land measuring developed by the surveyors in the Nile valley supplied much of the material from which the sciences of astronomy and geometry were built up but it was the Greek thinkers who first raised empi ricism to science. (See Burnet, Early Grek Philosophy, 3rd. ed., 1920, pp. 15 foll.)

3. Thucydides I, 2, 6 and I, 12, 4, makes this mistake and confuses the settlement of the Asiatic coast during the age of migration with the quite different and later process of colonisation, in which the Asiatic Greeks themselves took an early and important part.

4. For the problems of the chronology of the early" Semitic migrations see Peet, Egypt and the Old Testament, which is published in this series. Personally I incline to the view which dates the Entry into Egypt in the period of the $\mathrm{H}$ yksos or Shepherd Kings and regards the Exodus as part of the migrations of the XVth century B.C.

5. The Greeks greatly admired the tall stature of thePersians (Herodotus I, 139, Xenophon, Anabasis, III , 2, 25). The exceptionally tall woman who impersonated Athena to escort Peisistratus home from exile was only $5 \mathrm{ft} .10 \mathrm{in}$. (Herodotus I, 60, see How and Wells, Commentary on Herodotus, ad loc., Glover, F rom Pericles to Philip, p. 200). The "fair haired Achaeans" of Homer survived in historical times only upon the stage where dramatic tradition 
W. R. Halliday, The Growth of the City State, 16 favoured a fair-haired ( $\xi \alpha v \theta o ́ s)$ hero. 
Lecture II. Geographical Influences: The Greeks and the Sea.

The Balkan peninsula consists of a tangled mass of limestone mountains, of which the adjacent islands are merely the continuation. There is but little arable land in the small plains and that little is for the most part stony, very different from the fat alluvial mud of Egypt. Although deforestation has no doubt diminished the rainfall and assisted the erosion of the soil on the mountain flanks, the farming conditions in antiquity were not so very different from those of modern Greece. The foll owing statistics are given in Baedeker's Guideto Greece, 1909. Of the total area of modern Greece 18 per cent, is arable, 8 per cent, meadows and pasture, 9 per cent, forest and the other 65 per cent, mountain land covered, where it is not bare rock, with prickly scrub which is useless except for the summer grazing of sheep and goats. Only a few farms in the Thessalian plain exceed 250 acres, the average holding is from 12 to 50 acres, descending in the islands as low as 1 or $1 \frac{1 / 2}{2}$ acres. The climate is col d in winter when the snow lies deep on the mountains and the north wind blows down from them to the plain; in summer it is hot and parched. ${ }^{1}$ It is a difficult climate to live in and to some extent assisted eugenics by limiting survival to the fittest. ${ }^{2}$ It is essentially an open-air climate, a fact of considerable influence on the social history of the Greeks. It explains their objection to sedentary and indoor occupations ${ }^{3}$ and their contemptuous attitude towards industry. It led also to a life spent largely in themarket-placeand a predisposition to pol itical activity. The home is not so important as under the conditions of life imposed in northern latitudes. This in turn adversely affected the position of women. ${ }^{4}$

When the ferment of the Dark Ages subsided it left deposited in the pockets of this mountainous mass, settlements of people who had abandoned the nomadic for the static existence. The settlements were for the most part cut off from each other by the mountains and the sea. Land communications were difficult, particularly in winter, when the snow lies 


\section{W. R. Halliday, The Growth of the City State, 18}

deep. I n consequencethecommunities devel oped in independence of their neighbours, and it is due ul timately to this geographical condition of their growth that independenceis the key-noteof Greek civilisation throughout its political history. On its good side it shows itself in a passionate love of freedom; on its bad, in an inability to combine for a common object, a defect which ultimately ensured the political failure of the city state.

It has already been mentioned that the soil of these pockets in the mountains is poor in quality. It is clear that as population increases the stress of economic conditions is bound to be felt. For relief the Greeks were driven to sea. And here nature who had applied the stimulus of necessity, completed her work with encouragement. A glance at the map will show an abnormally indented coast-lineproviding a series of natural harbours. The great depth of many of these, which in modern times is a serious disadvantage, was of little account in the early days of sailing, when the small vessels did not need to anchor but were moored or beached, and though many of them lie open to southerly gales it is only in winter, in any case a close season for the small sailing vessel, that the wind prevails in this quarter. Besides supplying harbours, nature had also provided routes. Crete shuts in the bottom of the Aegean making it almost an inland sea. Towards it run down the Cyclades, a continuation of the mountains of Euboea, and to meet this chain of mountain tops pointing south-east, come the similar continuation of the mountains of Asia Minor, which run east and west. The resulting stimulus to early navigation cannot be exaggerated. It is possi ble to voyage from Athens to Smyrna without losing sight of land. In case of need the early mariner is thus enabled to run for shelter from the storm under the lee of the nearest island while, still more important, the island chains enable him to find his way. Without sextant, compasses, or charts, he is unable to make a dead reckoning, and out of sight of land is at the mercy of chance for his direction. The islands of the Aegean, however, provide a continuous series of landmarks. A further assistance to early navigation was provided by the Etesian winds, which not only mitigate the torrid heat of summer but serve also as a trade wind blowing steadily from the north from J une to September. 


\section{W. R. Halliday, The Growth of the City State, 19}

An example may show how dependent was the ancient Greek sailor upon weather conditions and upon the sight of land to guide him. The island of Thera had been without rain for seven years, and in consequence was suffering from the economic distress produced by prolonged drought. The inhabitants applied to Del phi who recommended the rel ief of a colony in Africa. The Theraeans sent a committee to make enquiries in Crete. There they came on a purple fisher, Korobios, who had discovered the island of Platea off the Libyan coast by the chance of being carried there by a storm. An expedition was then sent with Korobios to investigate the site. After inspecting it they returned to report, leaving Korobios with several months' supply of food. They were long away, and the supplies were giving out when the situation was saved by the arrival of a Samian ship. This had been making for Egypt and had been carried out of its course by contrary winds. After supplying Korobios she put to sea again still intending to make Egypt. She met easterly gales and was eventually carried to Tartessus in Spain! ${ }^{5}$

Indeed to the end classical navigation was limited by its lack of instruments and its dependence upon theweather. All through the winter that Iulius Caesar was perilously involved in Egypt, no news at all reached Rome, and the skipper of St. Paul's vessel would have done well to follow the Hesiodic rule as to seasons, though he was right in refusing to stay in the harbour of the Fair Havens, exposed to the full violence of the southerly gales of winter.

After losing sight of Clauda (the modern Gavdo) they lost all clue to their whereabouts and when eventually they were wrecked upon Malta, were quite ignorant, until they got ashore, of what land it might be. ${ }^{6}$

Hesiod whose poems reflect the agricultural stress of the eighth century B.C. and the mingled economic and political grievances which were driving men to sea, gives sound directions to the early navigator. No sane man will put to sea in the gales of winter. When the autumn rains begin, after the setting of the Pleiades, you should haul out your ship and lay her up, taking good care to store the tackle in the house where it will not rot with the damp, and hanging up the rudder in the smoke. ${ }^{7}$ The best season for putting to sea is from fifty days after the spring solstice to the 


\section{W. R. Halliday, The Growth of the City State, 20}

end of the summer heat. Except for squalls, you then have nothing to fear. Winds are favourable and the weather cal m. ${ }^{8}$ But avoid delay until the autumn rains when the southerly gales of winter set in. There is a spring season also, but not to be recommended. There is too much risk of bad storms. At this season, the wise man will not put more than a fraction of his fortune in one cargo, for the risk of losing it is too great. ${ }^{9}$ Of course seafaring though profitable is al ways risky, ${ }^{10}$ but a big ship is safer than a small, and you must operate on a certain scale in order to make it pay. ${ }^{11}$ It is not choice but poverty which drives men to sea. In a society blessed with a perfect ruler, heaven would give righteousness its due of perfect prosperity; the land would produce food for all and seafaring would be unnecessary. ${ }^{12}$

The Greeks, then, were both driven and encouraged to take to the sea, and it was as a race of sailors that they developed prosperity and ousted the Phoenicians from the carrying trade of the Levant. Both their harbours and their island routes point east and south towards Asia and Egypt, and led them into contact with the older civilisations. The west coast of the peninsula is comparatively harbourless. In consequence, the Western Greeks lagged behind in civilisation. Thucydides can point to the Acarnanians and their neighbours, as an example surviving in his day of the primitive conditions under which the ancestors of the more civilised states must oncehavelived. Themountaineers of the central Pel oponnese similarly lagged behind because they were denied immediate access to the sea. Here over-population was relieved principally by the individual emigration of members of a fighting stock, who, like the Swiss of the fifteenth and sixteenth centuries in E urope, sought their fortunes abroad as mercenary sol diers. ${ }^{13}$

It was the settlements on the islands and on the coasts of Asia that led the way in navigation and consequently in civilisation. Theearliest Greek literature, the Homeric poems, hails from the Asiatic side of the Aegean. Here, too, the foundations of science and philosophy were laid and the greatest commercial prosperity attained. The Odyssey is witness of the antiquity of the penetration of the Black Sea by the adventurous daring of the sailors of Ionia, and the foundations of Miletus are among the 


\section{W. R. Halliday, The Growth of the City State, 21}

earliest and most important Greek colonies.

Several causes contributed to the more rapid development of Greek civilisation on the far side of the Aegean. The mountains of the plateau which forms the body of Asia Minor run east and west, and the Greek settl ements were situated on the coast near the mouth of the river valleys running down from the interior. ${ }^{14}$ Together ther efore with the advantage of the fertile alluvial soil of the river mouths, they possessed the inestimable asset of controlling the terminal points of the channels of trade, which flowed down the natural routes of the river valleys to the sea. It is possible that the rapidity of their devel opment owes something to other causes. In some cases, at least, the first settlers came without women folk and married the natives of the country. ${ }^{15}$ Something may be due to the precocity of a mixed race. It has been suggested also (though archaeol ogical investigation has not gone sufficiently far in this area to warrant more than a hypothesis) that the BronzeAgecivilisation had not been so completely destroyed here as in mainland Greece. However that may be, the main factor with little doubt was the contact through the Asia Minor land routes with the products of the older civilisations. The same geographical factor which made them great was tolead to their fall. Armies as well as trade can pass down the river valleys. While their position at the end of the routes ensured their material prosperity, it no less invol ved the pol itical consequence that the Greek settlements at the river mouths must always be at the mercy of the military power which controlled the hinterland.

Thetimeat which thesettlements weremade was fortunate. TheH ittite empire which had controlled the central plateau was breaking up. Phrygia and Lydia, the states which successively emerged as the rulers of western Asia Minor, were by no means purely Oriental, but racially were the products of that infiltration of European stocks into Asia, to which reference has already been made. They tempered while they transmitted Oriental culture, and they were themsel ves susceptible to Hellenising influences. Although Lydia exercised control over the majority of the Greek towns of the coast, her rulers were philhellenic in general policy. It was not until the downfall of Lydia in the middle of the 


\section{W. R. Halliday, The Growth of the City State, 22}

sixth century that the Greeks of Asia were brought into direct contact with a purely Oriental empire. Their subsequent revolt in the first years of the fifth century was a hopeless protest against geographical circumstance. Their natural and characteristic difficulty in maintaining consistently united action, was accentuated by their lack of lateral communications except by sea, and when Persia mobilised her armies they fell an easy prey to the dominant military power of the interior. At the sack of Miletus, the glory of I onia was taken away. The lead in civilisation definitely passed to mainland Greece. Herodotus thehistorian and Anaxagoras the philosopher alike find their home and their patrons in Athens.

The fall of the premier commercial states in Asia left the way clear for the commercial supremacy of Athens, which had remained until thel atter half of the sixth century a second-rate state. The pioneers of early commerce and colonisation had been Chalcis and Eretria, Corinth and Aegina, the islanders, and the states of Asia Minor. But at the end of the seventh century B.C., Chalcis and Eretria had bled each other to death in the Lelantine war. The advance of Persia had broken the commercial states of Asia and the islands. With Aegina, which visibly lies across the mouth of Athens' outlet to the sea and disputes the control of the Saronic gulf, Athens had necessarily been at war, broken only by their common patriotism in face of the Persian invader, since first she had secured her hold on Salamis and begun to extend her influence beyond the borders of Attica. ${ }^{16}$ The resources of the Athenian empire were now used to break her power completely. ${ }^{17}$ Cor inth remained powerful though menaced. Her interests were mainly in the western trade, and jealousy of Athens' encroachments in the western seas was the cause of her bitter political hatred, and a contributing factor to the outbreak of the Peloponnesian war. ${ }^{18}$ The result of the successful defeat of the Persian invasion of Greece, and the subsequent formation of an anti-Persian maritimeleague with Athens at its head, was the Athenian empire. TheAegean thus came under the control of a single power, the mistress of what was in effect a commercial as well as political combination. ${ }^{19}$ It was to the interest of the predominant partner to police the seas and the conditions of commerce 


\section{W. R. Halliday, The Growth of the City State, 23}

were changed for the better. From thelegendary times of the return from Troy when N aupl ius avenged the wrongs of his son by lighting misleading flares which enticed his victims on to the rocks, wrecking had been a profitable pastime of the smaller islanders. Wrecking was put down with a firm hand by the mistress of the Seas. As the result of the complaints of merchants Scyros was reduced in 475 B.C. and Athenian settlers were planted in the island.

From the earliest times, too, trade and piracy had gone hand-in-hand. "Are you pirates?" was the first question asked of newly arrived voyagers in Homer's time, a fact which, as Thucydides notes, points to the then honourable status of the profession. ${ }^{20}$ Commercial rivals were naturally in a constant state of war. The three great rivals in the Egyptian market, Samos, Miletus, and Aegina, were bitter enemies and plundered each other's ships or territories as opportunity offered. ${ }^{21}$ The rivalry of contiguous states led often to their mutual destruction by exhaustion, as in the case of Chalcis and Eretria. But apart from the rival ry of commercial powers indiscriminate piracy was rife. The trader was not protected by law on the high seas, nor in a foreign port, unless specific agreements existed between it and his native state. Among the enemies of the state on whom the Teians, returning to their homes after the Persian war call down the most solemn curse, are those who "practise piracy or harbour pirates with knowledge, when they are plundering in the Teian territory or on the sea."122

The big commercial states before the Athenian empire, combined piracy with trade if sufficiently powerful to afford it. ${ }^{23}$ Samos is a good example of such a robber state. She enjoyed natural advantages in her situation at the end of the island route to Asia, and in a central position as regards the I onian coast, a geographical circumstance which subsequently gave her strategical importance in the Persian and Peloponnesian wars. ${ }^{24}$ Trade by sea was as confined to definite routes as trade by land, owing to the limitations of early navigation which we have al ready discussed, and in consequence it was possible for a naval power to occupy the same relative position at sea as "the fortified centres of exchange" of early Greek history on the land isthmus routes. ${ }^{25}$ Polycrates who raised Samos 


\section{W. R. Halliday, The Growth of the City State, 24}

to a first-class naval power in the second half of the sixth century plundered all trade indiscriminately. ${ }^{26}$ Valuables sent by sea had a habit of finding their way to Samos. ${ }^{27} \mathrm{His}$ public works, the wonders of Samos, were built with the slave labour of his captives. ${ }^{28}$

The Athenian empire did away with this state of disorder. Athens, it is true, did privateering on her own account at the expense of states outside the league ${ }^{29}$ but indiscriminate piracy was put down, and if the subject states lost by political subjection, and had to complain of the inconvenience of sending commercial disputes to the Athenian courts and of the partiality of the verdicts, they gained the inestimable commercial benefit of security on the high seas and in the harbours of the league. In fact the Athenian empireconferred upon theGreek world two benefits which were hardly appreciated at their true value by its contemporaries. The Athenian fleet secured for trade the freedom of the seas from pirates, and it supplied the indispensable condition for the political freedom of the Greek states of Asia Minor. For the indisputable mastery of the sea by a powerful Hellenic state discounted that hel plessness against invasion by land which the geography of Asia Minor imposed, as we have seen, upon the Greek towns of the sea-board.

The history of the fourth century demonstrated the truth of this double claim. After the destruction of Athenian sea-power the diplomatic question of the autonomy of the Asia Minor Greeks was academic only. Without a Greek fleet in command of the Aegean behind them, their return to Persian control was inevitable as soon as Persia troubled to insist upon it. The destruction of Athenian sea power equal ly necessarily involved the recrudescence of piracy. Disorder, aggravated by theresults of a long war which had filled the Levant with ruined and desperate men, reigned throughout the eastern Mediterranean. Privateers and pirates abounded, and there were at least somegrounds for theexaggerated fears of the coward in Theophrastus, who thought that every rock was a pirate vessel. ${ }^{30}$

Piracy has always been endemic in the Mediterranean. In the first century B.C. the trouble reached such serious proportions that the corn supply of Rome was endangered. As a result in 67 B.C. Pompey the Great 


\section{W. R. Halliday, The Growth of the City State, 25}

was given the command, with extraordinary powers to deal with a situation which incompetent handling had aggravated, and successfully cleared the seas and islands. Under the Roman Empire the Mediterranean again enjoyed the peace and prosperity of a single strong rule, but after its fall until the nineteenth century piracy again became normal. Indeed the journals of the travellers in the Levant, from the sixteenth century to the nineteenth, give an excellent picture of the kind of conditions under which trade must have been conducted in the old days of the rivalry of Miletus, Samos and the rest. Each strange sail is eagerly or anxiously scanned as a possible prize, if pal pably inferior in strength; as a possible captor, if superior.

Thucydides noticed that in his day cities were being built upon the sea shore, whereas ol der foundations were invariably built away from thesea upon the hill, because of the insecurity of the days of unchecked piracy. The same phenomenon may be noticed to-day. It is only since the bombardment of Alexandria in the nineteenth century, that there has been sufficient security to warrant the greater commercial convenience of building towns at the quaysi de. A good exampleis the chi ef commercial port of the Cyclades, Syra. The town beside the sea is purely modern, the older settlements, both the Catholic and Orthodox, are perched on the twin hills behind.

\section{Notes to Lecture II.}

1. Hesiod describes the climate of Ascra as "bad in winter, hard in summer, never good" (Works and Days, 640). In winter "when the North Wind rides down from Thrace, the wild beasts shiver and put their tails between their legs. Their hides are thick with fur but the cold blows through them and through the bull's hide and the goat's thick hair." Then good little girls sit safe and snug at home by the fire (Works and Days, 504 foll.) and their fathers are tempted to linger gossiping by the smithy fire, a waste of valuable time which might be spent mending and making gear (Works and Days, 493).

2. See Zimmern, Greek Commonwealth, pp. 33, 55. Thus Herodotus attributed the good health of the Egyptians to the constancy of their 
W. R. Halliday, The Growth of the City State, 26

climate, for in all changes and particularly in changes of season men are peculiarly liable to disease (Herodotus, II, 77, cf. Hippocrates, Aphorisms, III, I. "Changes of the seasons are prolific of diseases and great alterations of temperature whether of cold or heat.") Plato alludes to the evils attendant upon changes of season or wind as common knowledge (Laws VII, 797 D).

3. See bel ow Lecture VII, note 5.

4. "It is not so good for a woman to be out of doors as in and it is more dishonourable for a man to stay in than to attend to his affairs outside." (Xenophon, Oeconomicus, VII, 30, cf. ib. VII, 3). Pericles defined the good woman as one who is least spoken of by men whether for praise or blame (Thucydides, II , 45). Respectable women appeared in public only at religious festivals. Full references on this subject will be found in Headlam-K nox, Herodas, in the notes on Mime I, 11. 37, 56

5. Herodotus, IV , 151, 152.

6. Acts of the Apostles xxvii.

7. Hesiod, Works and Days, 618 foll. Plato mentions the strangers "who come and stay throughout the summer; this class are like birds of passage, taking wing in pursuit of commerce and flying over the sea to other cities while the season lasts" (Laws XII, 952 E). My experience of making weekly returns of thesailing vessel traffic from Cretan harbours during the War amply confirms the seasonal directions of Hesiod and other ancient writers.

8. Works and Days, 663-677, "Thou shalt not break thy ship, nor shall the sea destroy thy crew, save only if Poseidon, the Shaker of the Earth, or Zeus, the king of the immortals, be wholly minded to destroy."

9. Works and Days, 678. The caution against risking too much applies, I think, to the Spring season. "Neither set thou all thy livelihood in hollow ships; but leave the greater part and put on board the less. For a dread thing it is to chance on doom amid the waves, even as it is dread to put too great a burden on a waggon and break the axle while the goods are lost" (ib. 689-691). 


\section{W. R. Halliday, The Growth of the City State, 27}

10. Works and Days, 618. "Howbeit if desire of stressful seafaring seize thee." Cf. ib. 646. "When thou wouldest turn thy foolish soul to trafficking to escape debts and joyless hunger."

11. "Praise thou the small vessel but set thy goods in a large. Greater the cargo and greater the gain will be, if the winds refrain their evil blasts" (Works and Days, 643).

12. "They flourish with good things continually neither go they on ships but bounteous earth beareth fruit for them" (Work and Days, 236). "E ven as thy father and mine, fool ish Perses, was wont to sail in ships seeking a goodly livel ihood; whoalso on a timecamehither, traversing great space of sea in his black ship from Aeolian Kyme: not fleeing from abundance nor from riches and weal but from evil penury which Zeus giveth unto men." (ib., 633.) This view of seafaring became a literary common-place, eg. "Avoid busying thee with the sea and put thy mind to the plough that the oxen draw, if it is any joy for thee to seethe end of a long life. For on land there is length of days but on the sea it is not easy to find a man with grey hair." (Anthology VII, 650, cf. VII, 532. For victims of September gales see Anthol ogy VII, 392, $395,495,501,502,503,534.539$.)

13. Thus in the fragment of the comic poet Hermippus which details the commodities which come to Attica from various places, Phrygia supplies slaves and Arcadia mercenaries (Athenaeus I, 27). For Arcadians in Athenian service, see Hicks and Hill, Greek Historical Inscriptions, No. 56 referring to Melesander's expedition in 430. They were fighting on both sides during the Athenian operations against Syracuse. "But the Mantinean and other Arcadian mercenaries, men ever accustomed to invade any enemy pointed out to them and now influenced by a desire for gain, regarded as enemies as much as any even those other Arcadians who went thither with the Corinthians" (Thucydides VII , 57, 9; cf. Xenophon, Hellenica VII I I 23, Anabasis, VI , 2, 9 and 3, 1-9). Wefind individual Arcadians rising to prominence in Sicilian service eg., Praxiteles the Arcadian (Hicks and Hill, No. 15), Phormis of Maenalos (Pausanias, V, 27), Agesias the Stymphalian (Pindar, O/., VI). In modern Greece something of the same 


\section{W. R. Halliday, The Growth of the City State, 28}

role is played by the Sphakiots from the White Mountains in Crete.

14. The harbours are near not at the river mouths because the rivers of the Eastern Mediterranean are not navigable and the winter spates bring down silt which forms bars. The analogy of our tidal estuaries is misleading. (See Zimmern, op. cit., pp. 37, 38).

15. E.g., Miletus, Herodotus I, 146.

16. The early commercial importance of Aegina is shown by the fact that the earliest coinage in European Greece was the Aeginetan (see Hill, Historical Greek Coins, pp. 3 foll.). Prosperity of Aegina (Herodotus V, 81); the wealth of Sostratus the Aeginetan (Herodotus IV, 152). Trade with Egypt see note 21 below; with the Black Sea "Xerxes sees the Aeginetan corn ships coming through the Dardanelles" (Herodotus VII , 147); with Croton in I taly (Herodotus III , 131). The wars between Athens and Aegina are narrated in Herodotus V, 79-88, VI, 49-73, The account is very confused and in detail presents insuperable difficulties. Macan, in his edition of Herodotus, makes the best of a bad business. The feud with Aegina hel ped Themistocles to carry his naval policy (Herodotus VII, 144, Thucydides, I, 14). Adjustment of quarrel in view of the Persian danger (Herodotus, VII, 145).

17. Aegina was defeated and besieged in 459 (Thucydides I, 105), captured and made tributary in 457 (Thucydides I, 108). Home Rule for Aegina was guaranteed by Athens in the Thirty Years' Peace but was never carried out (Thucydides I, 67, I, 139, I, 140). In 431 B.C. as a precautionary measure at the outbreak of the Peloponnesian War the Aeginetans were expelled and Athenian settlers planted in the island (Thucydides II, 27). These settlers supplied a contingent at Mantinea in 418 (Thucydides V , 74) and in the Syracusan expedition (Thucydides VII, 57) and played a part in setting up the Four Hundred in 411 (Thucydides VIII, 69). The Aeginetan exiles were given a home by Sparta in the Peloponnese but in 424 fell into the hands of the Athenians and were put to death (Thucydides IV, 57). During the war the island was used as a naval base (Thucydides II, 31) and it was of importance because it covered the route through Epidaurus to Argos, whose traditional hostility to Sparta it was the 


\section{W. R. Halliday, The Growth of the City State, 29}

aim of Athenian politicians to exploit (Thucydides V, 53). The fear aroused by the threat of a Spartan attack upon Aegina in 411 contributed not a little to the downfall of the Four Hundred (Thucydides VIII, 92).

18. In the struggle between Athens and Aegina Corinth consistently pursued the obvious policy of supporting the weaker party against the stronger. Thus beforethe Persian War she had hel ped Athens against Aegina (Herodotus VI, 89, Thucydides I, 41) but the growth of the Athenian empire had altered the balance of commercial powers and in the war for the mastery of the Saronic Gulf (459-457) Corinth supported Aegina. Themistocles had directed democratic Athens towards a policy of expansion in the west. Athens' control of Megara with its ports on either sea (459-447), her acquisition of Naupactus (459), the friendly relations established with the I onian islands and the naval demonstrations in the Corinthian Gulf of 456 and 453 constituted a direct menace to the Corinthian control of the western seas. That Athens was unable to pursue the advantages which she had gained in this quarter and was obliged to abandon the western policy in 452 was due to her ambitions having over-reached her strength and particularly to the exhausti on caused by the unfortunate entanglements in Egypt, which ended in catastrophe in 454. It is true that Corinth opposed Peloponnesian intervention when Samos revolted from Athens in 440 (Thucydides I , 41) but, besides the desire inspired by her relations with Corcyra to set up a precedent for noninterference between imperial states and their subjects, she must have been loth to jeopardise the recovery of her navy and mercantile marine which was but beginning to regain strength after the losses incurred in the wars with Athens. In 432 her attitude was different. It was Corinth who urged an active policy upon Sparta (Thucydides I, 67) and canvassed the members of the Peloponnesian League individually in favour of war (Thucydides I, 119).

19. "And as to the states subject to Athens which are not islanders but situated on the continent, the larger are held in check by apprehensi on and the small ones absolutely by want, since there is no state in 


\section{W. R. Halliday, The Growth of the City State, 30}

existence which does not depend upon imports and exports and these she will forfeit if she does not lend a willing ear to those who are masters of the sea" ([Xenophon], Constitution of Athens II , 3, cf. ib. II, 11). States like Carystus in Euboea which objected to join the League might be forced to do so. To justify such action of course a case may be made similar in character to that of the Trades' U nion for compelling all members of its own trade to become members. Athenian weights and measures and Athenian coinage were introduced throughout the Empire (see Gardner, History of Ancient Coinage, B.C. 700-300, pp. 226 foll.). Again though the enforcement of this uniformity was an instrument for asserting Athenian domination, there is justification for it in its obvious practical advantages.

20. Thucydides I, 5. "Strangers, who are ye? Whence sail ye over the wet ways? on some trading enterprise or at adventure do ye rove, even as sea-robbers, over the brine, for they wander at hazard of their own lives bringing bale to alien men" (Odyssey III , 72, IX, 252). Cretan raid on Egypt (Odyssey XIV , 245). I onians and Carian freebooters in Egypt (Herodotus II, 152).

21. At Naucratis, not it should be noted a colony but unique as a trading port in a foreign country under a royal charter, the Aeginetans, Samians and Milesians had separate temples. The lesser mercantile states shared a common temple, the Hellenion. These were Chios, Teos, Phocaea, Clazomenae, Rhodes, Cnidu?, Halicarnassus, Phaselis and Mitylene. It is worth noticing that except for Aegina Egyptian trade in the sixth century was completely in the hands of Asiatic Greeks. (Herodotus II , 178-179). Ancient enmity of Aegina and Samos (Herodotus III, 59). In 525 Aegina prevented the Samian exiles from settling at Cydonia in Crete. The hostility of Samos and Miletus (Herodotus III, 39) was carried on by the settlers, who returned after the sack of Miletus by the Persians, and was the occasion of the Samian revolt in 44.0 which shook the Athenian empire to its foundations (Thucydides I, 115). In the Lelantine War Samos had been on the side of Chalcis, Miletus of Eretria (Herodotus V, 99) and in the west the connections of Aegina and Samos were with Croton, 


\section{W. R. Halliday, The Growth of the City State, 31}

those of Miletus with Sybaris. At Sybaris the Milesian wools were disembarked for transport across the peninsula thus avoiding the straits of Messina and the strong arm of the rulers of Messina and Rhegium. At Laos, the western port of Sybaris, they were reshipped for the Etruscan market. It is therefore intel ligibleenough that when Sybaris was destroyed by Croton the Milesians went into mourning (Herodotus VI, 21).

22. Hicks and Hill, No. 23. For glimpses of the freebooters' life at sea in the seventh century see the poems of Archilochus. "In my spear is kneaded bread, in my spear is wine of Ismarus and I lie upon my spear as I drink" (Bergk, Poetae Lyrici, Frag. 2, cf. Frag. I; Frag. 59 is perhaps the Greek equivalent of "Fifteen men on the dead man's chest"). The treaty between Oiantheia and Chaleion, two states geographically well placed for plundering the pi Igrim traffic to Del phi, illustrates the legal position of a merchant in a foreign port which had no specific commercial agreement with his native place. "No Oiantheian, if he make a seizure, shall carry off a foreign merchant from Chaleian soil, nor a Chaleian a merchant from Oiantheian soil; nor shall either Oiantheian or Chaleian seize a merchant's cargo within the territory of the other city. If anyone breaks this rule, it shall be lawful to seize him with impunity. The property of a foreigner may be seized on the sea without incurring the penalty, except in the actual harbour of the city." (Hicks and Hill, No. 44.) For the whole question of ancient piracy and privateering reference may be made to the forthcoming book in this series by Mr. H. A. Ormerod, for which his admirable article "Ancient Piracy in the Eastern Mediterranean," Liverpool Annals of Archaeol ogy, VIII, pp. 105-124 was a preliminary study.

23. Thus when the Corcyreans pleaded their diplomatic isolation the Corinthians insinuated that Corcyra had deliberately avoided specific agreements with other states in order to leave her hands free for piracy, a policy made possible by her remoteness and her naval strength. (Thucydides I, 37.)

24. After Salamis the Persian fleet took up position at Samos because 
W. R. Halliday, The Growth of the City State, 32

from there it could keep one eye on the menace of the Greek fleet crossing the Aegean and the other upon possible disaffection in I onia. The geographical position of the island made the fidelity of Samos of the first importance to Athens in the closing stages of the Pel oponnesian War.

25. E.g., Troy, Tiryns and Mycenae which owed much of their prosperity to the control of trade which crossed their isthmuses by land. (See Zimmern, Greek Commonwealth, p. 24. Murray, Rise of the Greek Epic, 2nd ed., p. 59.)

26. Herodotus III, 39.

27. E.g., Amasis' gift to Sparta (Herodotus III, 47); Sparta's gift of a bronze bowl to Croesus (Herodotus I, 70); the Corcyrean boys sent by Periander to the king of Lydia (Herodotus III, 48).

28. Herodotus II, 39. The wonders of Samos (Herodotus III, 60). The historian displays a special interest in Samos and Samians for, when he fled from his native Halicarnassus, he found a refuge there.

29. Thucydides II , 69, III , 19.

30. Theophrastus, Characters, xxvii. References to privateering, piracy and kidnapping are frequent in the Attic orators e.g., Lysias, Against the Corndealers, XXII, 14, Isocrates, Trapez, 35, 36, Paneg, 115, Demosthenes Nicostr, 6. 
Lecture III. Geographical Influences: The Western

Mediterranean.

Our attention hitherto has been concentrated chi efly on theeastern part of the Mediterranean, we must now turn to the west. I t has al ready been noted that the Acarnanians and their neighbours had remained in a backward state and represented to Thucydides a survival of a more primitiveculture. What importancethenorthwestern coast possessed was due to the trade route with the west. The ships of Corinth, who of the mainland Greeks possessed the monopoly, would sail out of the Corinthian gulf and up the passage sheltered by the I onian isl ands to Corcyra. From here there is but a short journey across the mouth of the Adriatic to the heel of I taly.

Corcyra had been a very early foundation of Corinth. Owing to its size, its fertility, and its advantageous position on the trade route, it rapidly developed in power and became a rival to the mother-country. In consequence Corcyra is the outstanding exception to the rule that Greek colonies entertain sentimental ties and friendly relations with their mother state. The earliest sea battle was said to have been fought between Corinth and Corcyra. ${ }^{1}$ The policy of Cypsel us and Periander, the great tyrants of Corinth of the middle of theseventh century, was to build up a Corinthian empire al ong the line of the trade route. A necessity for its success was the reduction of Corcyra, but the island was too powerful to be held in thrall permanently by Corinth. ${ }^{2}$ Too remote to share the anxieties of the mainland states at the Persian invasion, Corcyra remained neutral. ${ }^{3}$ It was a renewal of the quarrel with Corinth which formed the occasion for the Peloponnesian war, and the fact that Corcyra was then the third naval power in Greece which tempted Athens to risk the results of Corinthian indignation by her intervention. ${ }^{4}$

The importance of Corcyra lay in her position on the route to Italy and Sicily. The I talian promontory, 650 miles long with a maximum breadth 


\section{W. R. Halliday, The Growth of the City State, 34}

of 150 miles, runs from N orth toSouth across the centre of the Mediterranean. It is continued in Sicily, which is divided from Italy by a very narrow strait and from Africa by a channel of something over 100 miles. $^{5}$ The central position of the Italian peninsula was in itself an important factor in the development of the domination of the ruler of the Italian peninsula over the whole of the Mediterranean.

The main physical featureto noticeis the range of the Apennines, which from its junction with the Maritime Alps runs across the breadth of the peninsula in an easterly sweep, and then follows down its length, keeping nearer the eastern than the western shore. I taly looks west rather than east and there are no good harbours between Venice and Brindisi. Further the lateral sweep of the range on the north cuts off Cis-Alpine Gaul from Central I taly, and therich country between the A pennines and the Alps, which is watered by the Po, appears late in Roman history. The second Punic War emphasised its al ready recognised importance, for the Po basin, apart from its natural resources, is an essential part of a united Italy for which the command of the Alpine passes is necessary as a defence against foreign invasion. In the part which lies below the mountain barrier of the Apennines I taly possesses no rivers of any size. Her streams like those of Greece are of the nature of mountain torrents, unnavigable for the most part and blocked at their mouths by bars formed of the silt washed down from the hills in winter. Unlike the Balkan peninsula she possesses few natural harbours, which is no doubt the reason why the Greek settlers pushed no further north than the bay of Naples. The Romans in consequence had never a predisposition for the sea, and indeed it was a political and military necessity which drovethem to build a fleet for the first time in the First Punic War.

I taly, unliketheBalkan Peninsula, was inhabited in palaeolithictimes, but in the later Stone Age this population was exterminated or absorbed by neolithic immigrants who, like the earliest settlers on the islands and shores of the Eastern Mediterranean, came probably from N orth Eastern Africa. Shells from the I ndian Ocean have been found in I talian neolithic graves. The homogeneity of the neolithic raceall over the M editerranean is shown both by their skull measurements, which uniformly show a long- 


\section{W. R. Halliday, The Growth of the City State, 35}

headed type and also by their funerary customs. In all parts of this area neolithic man buried his dead in a contracted position, laying with them objects for their use in the next world, which were often broken before being put into the grave. Red ochre was used for painting the skin of the living and often the bones of the dead. Secondary burial was common, i.e, the practice of burying the bones after the flesh has decayed or has been artificially removed.

Neolithic man reached Greece and the islands by sea from the south; it would appear that two streams invaded I taly, one from the south by sea through Sicily, and the other by thestraits of Gibraltar through Southern France and across the passes of the Alps, which, imposing barrier as they appear upon the map, have never proved a serious impediment to the movement of peoples. This prehistoricracetheGreeks call led I berians; the Basques of the fastnesses of the Pyrenees are probably the purest of their descendants to-day.

At the close of the Stone Age a different racial el ement made its way intol taly. Thelake-dwellers of the Alpinelakes and those of the marshes of the Upper Danube, made their way across the Alps and set up their pile dwellings in the I talian Lakes and along the water-logged forests of the Po valley. The intruders brought with them the use of bronze and developed the arts of agriculture. At a later date in the Bronze Age a further movement took place, and again the basin of the Upper Danube overflowed through the Iulian Alps. To this wave of invasion belong the terramara people, who spread from the lakes to the dry land, but remained faithful to their old method of architecture and continued to build their villages upon platforms raised upon piles. In the Bronze Age they covered with their settlements much of the country north of the Apennines, gradually they moved further south, and in the Early I ron Age developed the so-called Villanova culture. It was these tall, shortskulled Central E uropeans who becametheancestors of the Romans, and it is interesting to observe that the Roman camp of classical times is laid out precisely after the model of the old pile settlements of the terramara people. ${ }^{6}$

Invasion then as in the case of Greece, had been principally from the 


\section{W. R. Halliday, The Growth of the City State, 36}

north. Each new wave naturally pushed its predecessors further south, and except for the Adriatic slopes from Rimini southward, which retained its "neol ithic" population, and a small pocket of the neolithic I talians who had taken refuge in the Ligurian hills, the older inhabitants are to be found in Sicily and the south. In historical times the centre of I taly was inhabited by homogeneous tribes, speaking dialects of thesamelanguage which, no less than their system of social organisation, belongs to the Indo-E uropean type.

Two intrusive elements in the population of I taly must be mentioned. The Etruscans, whose origin is one of the unsolved problems of history but whom a probabletradition brings from the Levant, settled in I taly not earlier than the beginning of the eighth century B.C. They developed a high degree of material civilisation and provided both a market and a rival to Greek trade in the western seas. ${ }^{7}$ But their cities developed no power of political combination, a fact which doomed them to failure in the struggle with Rome.

The second intrusive element is the Greek. Cumae, traditionally the earliest of the Greek colonies, is said to have been founded before 1000 B.C., though the actual date cannot be earlier than the eighth century, and the heel and toe of I taly were early studded with Greek settlements. So prosperous indeed was Hellenism in I taly that the southern portion of the peninsula earned the title of Greater Greece. But, though prosperous, the character of Italian Hellenism was somewhat self-centred. It made great contributions to civilisation and it profoundly influenced the cultural devel opment of the I talian peoples; ${ }^{8}$ but owing to its remoteness it made but little direct contribution to the political history of Greece proper. ${ }^{9}$ It is in their relations to Sicily and Rome, that the Greek states of I taly become an important factor in the political history of Europe.

Sicily is divided from I taly by a strait so narrow as to afford little obstacletoinvasion. As regards the M editerranean theisland lies roughly in a central position and is marked out as the natural meeting-place for East and West. As regards I taly it is on the direct sea route to Africa and Carthage. Throughout her history therefore Sicily has been liable to foreign intervention. Her natural resources are sufficient to attract the 


\section{W. R. Halliday, The Growth of the City State, 37}

invader. The island is hilly inland, with fertile plains on the coast. The latter are notably rich on the east coast, where Etna provides the vol canic soil in which the vine particularly flourishes. It is a corn-growing land, important al ready in the fifth century as a source of supply for Greece, ${ }^{10}$ and afterwards to become one of the granaries of the Roman empire. There was good pasture on her plains. Unlikethe states of Greece proper, with the exception of Thessaly, the Sicilian states reared horses and the caval ry was an important arm in their wars. ${ }^{11}$

Before the arrival of the Greeks the Italian invasions had been prolonged across the straits of Messina and the Phoenicians had established their factories round the coasts. ${ }^{12} \mathrm{~J}$ ust as in I taly the more aboriginal peoples are found furthest south, so in Sicily they tend to be pushed west. The traditional date for the coming of the Greeks is given by the foundation of Naxos by the Chalcidians 735, and Syracuse by the Corinthians 734. The rich natural resources of the country are no doubt responsible for the rapid independent development of these colonies. Within 135 years after her foundation Syracuse had herself founded Acrae, Casmenaeand Camarina, whileN axos had colonised Leontini and Catana. Roughly the south-east corner of theisland was under Megarian and Corinthian influence, while the district north of Megara Hyblaea as far as the straits was of Chalcidian foundation. Messina, or Zankle, as it was earlier named, owing to the temptations of its position commanding the sea route through the straits and its proximity to Italy, had a chequered history. ${ }^{13}$

The Greeks drove the Phoenicians from their factories on the eastern shore, but the latter retained their hold on the harbours of the west and the western corner of the island was mainly under Phoenician influence. Thenatives here, Sicani and Elymi, bel onged to the older strata of Sicily's population. The central part of theisland was inhabited by theSicels, one of the races which had been pushed out of I taly and across the strait. They were susceptible to a considerable degree of Hellenisation but devel oped no capacity for political cohesion, a defect which ensured the failure of the interesting attempt of Duketios, a Hellenised Sicel to create a national Sicel state (461-440). The civilisation of the rest of the island 


\section{W. R. Halliday, The Growth of the City State, 38}

became absolutely Greek.

Up to the coming of the Greeks the pressure on Sicily had been from the east, after the eighth century it is from the west. Carthage, originally a foundation of Tyre, had devel oped into the premier commercial state of the western seas. ${ }^{14}$ She had no wish to follow the example of her parent Phoenicia, whose merchants had been driven off the sea by Greek enterprise. ${ }^{15}$ To preserve her monopoly of the western trade she made common cause with Etruria agai nst the Greek intruders and particularly in championing the cause of the Phoenician states in Sicily she became an imperial as well as a commercial state. The struggle of Carthage, working from the Phoenician corner of the island, against the Greek states, is the recurring theme of the history of Greek Sicily. It raged with varying fortunes but was not decided until the First Punic War, when Rome solved the dispute by driving out the Phoenicians and making the Greeks her subjects.

The Greeks in the west failed to take the carrying trade from the Carthaginian, as they had taken it in the east from the Phoenicians. But seldom can Greeks have passed beyond the Straits of Gibraltar, and the connection of Samos and Aegina with Tarshish seems to have been temporary only. Massilia, the outpost of Hellenism in thewest, remained isolated though the wealth of the Rhone valley enabled it to prosper in isolation. Attempts to establish intermediate links were crushed by the hostility of Etruria and Carthage. The African trade and the route to the tin islands were kept in Carthaginian hands, and the discoveries of Carthaginian merchants were jealously guarded as trade secrets. ${ }^{16}$

The commercial rivalry of Carthage and Etruria lent an air of romance to piracy in the west, and adventurous captains like Dorieus or Dionysius the Phocaean, harried the Semite in the same spirit as the Elizabethan seamen plundered the Spaniard. TheEI Dorado of the ancient Mediterranean in this way absorbed the moreadventurous spirits, who weredriven from their homes by the advance of Persia and formed an outlet for what might have proved a disturbing element in the Levant. ${ }^{17}$

The struggle with Carthage has further an important bearing upon the political history of Sicily, and is the parent of the idea, consistently recur- 


\section{W. R. Halliday, The Growth of the City State, 39}

ring, but never for long realised, of a national state larger than the city state. Owing to the exigencies of thestruggle which brought it into being, this idea took practical shape in the attempt to create a military despotism uniting the Greek states under a singlerule. Such a conception was profoundly anti pathetic to the love of independence, of a race whose chi ef political defect was their inability to combine to form a larger unit than the city state. Nowhere is this trait more markedly displayed than in the history of Greek Sicily, where union never outlasted immediate and urgent necessity.

Two further points may be noticed. The first is the specific influence of an event. The victory of Cumae in 474, which completed the work of Himera, and dealt the knock-out blow in the first round of the struggle between the Greeks and the Carthaginian-Etruscan combination, relieved the pressure on Rome in her struggle with the Etruscans in I taly, and so contributed to her subsequent rise to power in I taly.

The second is of wider and more general purport. Our survey has shown us the Greeks scattered outside the physical boundaries of the Balkan peninsula both in the east and the west. They form a consciously distinct nationality which is not, however, enclosed within a physical frontier. It foll ows that, when the outskirts of Hellenism are conquered by a foreign power the now familiar problem of nationality will be raised for the conqueror. The Persian conquered the cities of the Asia coast; he could not denationalise these recalcitrant subjects; just across the sea their brethren were enjoying freedom, inspiring discontent in those who had been subdued by the difference of their status, and even ready to help them in revolt. It was inevitable that the attempt should be made to remove a source of constant disorder by the conquest of the mainland Greeks as well ${ }^{18}$ On a smaller scale, the same problem recurs in the west: the cities of Sicily and South I taly are linked rather than divided by the Straits of Messina. The Syracusan tyrants found that to control a part at least of South I taly was necessary if their plan of a Greek empire in Sicily was to succeed. ${ }^{19}$ Similar is the fundamental cause of the First Punic War. When Rome had conquered Tarentum and the cities of South I taly, the conquest of Sicily was inevitably the sequel, and the late allies, Rome 


\section{W. R. Halliday, The Growth of the City State, 40}

and Carthage, were bound to cometo blows. Either Romemust add Sicily to her conquests in South I taly, or Carthage, from her vantage point in the west of the island, must add to her subjects the still free states of Sicily and the Italian Greeks as well. Roman statesmen must have realised this during the anxious moment when it was uncertain as to which of the allies, Rome or Carthage, Tarentum would choose to surrender.

There remains to be considered the geographical position of Rome and its influence upon her devel opment. I t has al ready been pointed out that in I taly plain and mountain are more distinct than in Greece, and that the country is not divided up into small compartments, separate in a tangle of mountains. The plain of Latium, inhabited by the Latin tribes, lies in a central position on the west coast of I taly. At its northern border the Tiber, a considerable stream as I talian rivers go, flows into the sea. The natural enemies of the tribes cultivating the fertile plain are the Etruscan cities of the north, and the highlanders of the surrounding hills, the latter racially akin to them. In early times an extinct volcano rising in the centre of the plain, the Alban Mount, served them as a religious centre and a city of refuge. F or a city of refuge it was admirably suited, but it was nothing more, and it must early have occurred to the Latins that the river was their natural line of defence on the north. Further there was a site where the river could be crossed and at the same time the crossing could be defended. Here Rome was planted as a fortified position on the hills commanding the ford. From the outset Rome was a military state, the outpost protecting the Latin plain on the north. The advantages of her position were considerable. By the river she had communication with the sea, and the mouth of the river afforded a possible though far from admirable harbour. Later this was to give Rome an outlet for trade with the outsi de world. I $\mathrm{n}$ a strong position on her hills her command of the crossing has commercial as well as military advantages, for trade going north or south to cross the river will pass through Rome. ${ }^{20} \mathrm{Her}$ peculiar position rapidly made Rome different from the other Latin states. The discipline of the long and uphill struggle with Etruria moulded her character and welded her citizens into a military 


\section{W. R. Halliday, The Growth of the City State, 41}

people. The champion of Latium against the north was invoked also against the highland tribes. Thechampion inevitably becamethemaster, while the allies, dependent for security upon Rome's military prowess, became politically subordinate to a military power, not only stronger in itself than any other single member but possessed of inner lines of communication, and from the very beginning a past master at dividing its enemies and dealing with them singly.

Rome then has her origin in a military need. Although the ancestors of the Greeks and Romans were in part of kindred stock, the conditions of their growth were very different, and both in history and temperament the two peoples present a complete contrast. The Greeks were an adventurous and imaginativerace. Thedaring of their speculations in the intellectual field rivals the daring of their seamen in uncharted seas. They were fond of first principles and believed in logic; if anything they were over-clever. Their legacy to the world is largely intellectual and aesthetic. They discovered the fundamental problems of moral and political philosophy, they devel oped an architecture and scul pture which has hardly been equalled and never surpassed, they laid the foundations of all the sciences from geometry to medicine. Their literature has survived in a number of works in proseand verse which are immortal and can never be made "dead" by time because, while exquisite in form, they are packed with thought about thestuff of human life, and those realities which must remain realities as long as human nature exists. The Romans on the other hand had no remains of a Minoan culture upon which to build nor were they driven to sea. Circumstances demanded of them and bred in them the virtues of the watch-dog. Courage was theirs rather than daring, tenacity rather than curiosity. They were not intellectual and not imaginative, but they had, what the Greeks had not, practical political instinct. For first principles they cared little and their primary concern was dealing with the immediate facts. A sound conservatism cautiously advances adjusting details as they call for treatment. ${ }^{21}$ It is, obviously, a policy which has its defects but it is playing the long game. It is a live policy and one consistent with steady growth. It has nothing to do with panaceas and complete schemes of change. And it is right. The 


\section{W. R. Halliday, The Growth of the City State, 42}

constitutional panacea means complete disaster if in fact the nostrum is not a success. In its nature, too, the panacea is a static ideal and politically is doomed in a world where development and change is a condition of vitality. ${ }^{22}$

You have then a people of practical, not artistic temperament, and a race whose strength lies in character not in cleverness, strong particularly where the Greeks were weak, in a sense of discipline. Compared with that of Greece, Rome's artistic legacy is small indeed. Even in literature it is not comparable. The material remains which have moved the admiration of Greek visitors or, in their ruins, of the modern world are characteristic: they areworks of practical utility - drainage systems, aqueducts, roads or bridges.

But Rome protected the intellectual discoveries of Greece and kept the world at peace for sufficient time to allow civilisation to take deep root in Western Europe. She developed a system of law which has formed the basis of the codes of all modern states and above all she taught a new conception of government. Vergil's proud claim was not unjustified.

Others will mould their bronzes to breathewith a tenderer grace, Draw, I doubt not, from the marble a vivid life to the face, Plead at the bar more deftly, with sapient wands of the wise Trace heaven's courses and changes, predict new stars to arise. Thine O Roman remember to reign over every race. These be thine arts, thy glories, the ways of peace to proclaim, Mercy to show to the fallen, the proud with battle to tame. ${ }^{28}$

Notes to Lecture III.

1. Thucydides dates the battle about 664 B.C. (Thucydides I, 13).

2. Corcyra was made subject and rul ed by a prince of the royal house. The foundation of the Corinthian and Corcyrean colonies on the Ambracian Gulf and the west coast of Acarnania form part of the same policy. Here too eg., at Leucas and Anactorium members of the tyrant's family were put in control. In the fifth century Corinth still sent out two magistrates yearly to Potidaea (Thucydides I, 56). It was very exceptional for a mother state thus to retain political control over a colony. In the case of Potidaea, which was also a member of the 
W. R. Halliday, The Growth of the City State, 43

Athenian empire, it was inevitablethat therival claims of Athens and Corinth should conflict.

3. Corcyra waited to see which side was going to win before irreparably committing herself; she made promises but her ships got no further than Taenarum. In 1911 I noticed a modern parallel to this indifference on the part of the I onian islands to the policy of the mainland, the mutual character of whose interests with their own is obscured in the popular mind by geographical separation. In the Cyclades and eastern Greece, through which I had passed, sentiment was enthusiastically in favour of the war against Bulgaria. In Leucas and Corfu for the first time I found the people indifferent or critical and their tone was "what does Macedonia matter to us western Greeks?"

4. Thucydides I, 44.

5. The sea passage from Lilybaeum to Carthage is roughly 130 miles.

6. The standard book on this subject is Peet, The Stone and Bronze Ages in I taly. The Terramara people are so called because I talian peasants gave the name terramara to the earth dug from the mounds which were in fact the decomposed remains of their settlements. The earth was used as a fertiliser.

7. The chi ef Etruscan export to Greece was metal ware, the chief import from Greece was decorated pottery, large quantities of which have been found in Etruscan tombs.

8. Both Etruscans and Latins derived their al phabet from Cumae.

9. Thus the only contribution by Magna Graecia in Greece's hour of need was one ship under the command of Phayllus the celebrated runner (Herodotus VIII, 47).

10. Thucydides III, 86. See Grundy, Thucydides and the History of his Age, p. 325. Dr. Grundy perhaps exaggerates the degree to which the Peloponnese was dependent upon the supply of corn from the west.

11. Gelo rose to power as a cavalry captain (Herodotus VII, 154) and cavalry played an important part in the victory of Himera. The story of Gelo's interview with the Greek envoys, who came to ask for help against the Persian, though no doubt apocryphal, reflects the current estimate of the island's resources. He offers cavalry, light armed 


\section{W. R. Halliday, The Growth of the City State, 44}

troops (cf. Thucydides VI, 20, 4) and corn supplies (Herodotus VII, 158). Nicias also emphasised the Sicilian strength in caval ry and her advantage of producing enough corn to be independent of imported supplies (Thucydides VI, 20, 4). Pindar's Sicilian patrons were frequent victors in the horse races and Sophocles (Oedipus Col oneus 311 foll.) refers to the Aetnean breed. Under the Roman empire enormous stud-farms were developed in the island to meet the constant demands of the Circus and "when Gregory the Great was selling off horses on the property of the Church in Sicily, a mere four hundred that were to be left seemed too inconsiderable to take into account" (Friedländer, Roman Life and Manners under the Early Empire, II , p. 25). Sicily also did a large export trade in cheese and pigs.

12. Thucydides (VI, 2-5) drawing probably on Antiochus of Syracuse, gives the following ethnological strata. (1) Cyclopes and Laestrygonians. (2) Sicans, whowereaborigines. (3) Elymi, immigrants supposed to be refugees from Troy, who in his time were to be found in the west of the island. (4) Phocians who also immigrated immediately after the Trojan War and also were to be found in the west. (5) Sicels who had been driven across the Straits of Messina from South I taly by the Opici (Oscans). (6) Phoenicians whosefactories were planted all round Sicily and on the islands off the coast until the coming of the Greeks drove them into the western corner.

13. Founded by Cumaean pirates and Chalcidians it was seized by the Samian exiles who had been driven from their home in consequence of the advance of Persia. Subsequently Anaxilas of R hegium, thetown across the strait, drove out the Samians and colonised it with a mixed race (Herodotus VII , 164, VI , 22, 23). Messina provided the ground for Roman and Carthaginian intervention in 264 B.C. and thus gave the occasion for the First Punic War.

14. Carthage, which was founded probably in the ninth century B.C., kept up model relations with the parent city Tyre and every year sent offerings to Tyrian Melkarth. The Carthaginians were true Semites. The names Hannibal and Hasdrubal are exactly equivalent to 
W. R. Halliday, The Growth of the City State, 45

Hananiah and Azariah of the Old Testament. Her two suffetes who are the executive of the state are shophetim, J udges as our translation of the Old Testament calls them. She was a mercantile state whose military strength was based upon a large mercenary army. Her government though nominally composed of a senate and assembly, and therefore classed by the Greeks as a "mixed constitution," lay really in the hands of a mercantile aristocracy. The great family of Barca, which plays the leading role in the struggles with Greece and Rome, represented imperialistic democracy and depended upon the support of the popular party. Hence their individual genius tended al ways to be hampered by having opposed to them at home the most influential elements in the state.

15. "As some grave Tyrian trader, from the sea,

Descried at sunrise an emerging prow

Lifting the cool-hair'd creepers stealthily,

The fringes of a southward-facing brow.

Among the Aegean isles;

And saw the merry Grecian coaster come,

Freighted with amber grapes and Chian wine, Green bursting figs, and tunnies steeped in brine;

And knew the intruders on his ancient home,

The young light-hearted Masters of the waves;

And snatch'd his rudder, and shook out more sail, And day and night held on indignantly

O'er the blue Midland waters with the gale,

Betwixt the Syrtes and soft Sicily,

To where the Atlantic raves

Outside the Western Straits, and unbent sails

There, where down cloudy cliffs, through sheets of foam,

Shy traffickers, the dark I berians come;

And on the beach undid his corded bales."

Matthew Arnold, The Scholar-Gipsy

16. See Zimmern, Greek Commonwealth, pp. 21-23 with the references there given. Herodotus only knows of the existence of the African trade beyond the Straits of Gibral tar by hearsay from a Carthaginian 


\section{W. R. Halliday, The Growth of the City State, 46}

source (Herodotus IV, 196). "The Carthaginians, if any sailed past them for Sardinia or the Pillars, used to drown him in the sea" (Strabo, XVII, 802 quoting Eratosthenes).

17. The disturbance caused by the advance of Persia filled the seas with desperadoes. E.g. the Samian exiles, after a vain attempt to return to Samos by force, with Spartan assistance, raised money by attacking Siphnos whose mines had not yet been submerged. Herodotus says simply "they were in need of money, and Siphnos was particularly prosperous at that time, indeed they werethe richest of theislanders" (Herodotus III, 57). The mines were subsequently destroyed by becoming submerged (Pausanias X, II, 3). With their spoils they bought the island of Hydra (Herodotus II, 59). They next occupied Cydonia in Crete but were forcibly ejected by Aegina who no doubt disliked the establishment of these piratical commercial rivals on the Egyptian trade route. Other Samian refugees after the defeat of the I onians at Lade accepted the invitation of Zankle (Messena) to colonise a neighbouring site and when they reached Sicily seized Zankleitself (Herodotus VI, 22-24). Dionysius the Phocaean after the defeat at Lade sailed first to Phoenicia where he sunk some galleys and thenceto Sicily wherehe carried on piracy against the Carthaginians and Etruscans but spared Greek commerce (Herodotus VI, 17). Dorieus an adventurous spirit, who was an unsuccessful claimant to the throne of Sparta, first attempted to plant a colony at Kinyps (Tripoli) in Africa but was driven out by the Carthaginians. He next went to I taly where hetook part on the side of Croton against Sybaris, and finally to Sicily where he died fighting against the Carthaginians and Segesteans (Herodotus V , 42-46). Phocaean exiles after a failure to buy the Oinussae I slands from Chios sailed west to Corsica. There "they plundered all their neighbours" until the settlement was destroyed by the Carthaginians and Etruscans (Herodotus I, 165-166). No doubt in addition to resentment at the pillaging of their commerce the Western Powers were determined to prevent an intermediate station being established between the Greek world and the Phocaean colony, Massilia. 


\section{W. R. Halliday, The Growth of the City State, 47}

18. Cicero, deRep. II , 49, said that the Greeks formed as it were a fringe round the coasts of the world. For the Persian problem of the ethnic frontier see Grundy, Great Persian War, pp. 60-64. The Scythian expedition of Darius was probably inspired by the necessity of finding an ethnicfrontier on his north-western boundary and the revolt of the Hellespontine Greeks during his absence on the Danube must have emphasised the urgency of the Greek question. The Greeks were the most fractious of his subjects; they clearly could not be denationalised. The free Greeks were constantly inviting intervention, and political refugees at the Persian Court clamoured for assistance. The task of conquest cannot have seemed difficult in view of Greek disunion and Persian resources. The I onian revolt when free Greeks sent hel p to his insurgent subjects made action inevitable. But already when the Danube frontier had been settled and the Greek problem was being considered, doubts may have arisen in Darius' mind whether the conquest of the Greek mainland would finally solve the problem unless Hellenism in the west were also included. That seems to bethe suggestion of the story of the spies who were sent with Democedes to report upon the character and distribution of Hellenism in Europe (Herodotus III, 129-138).

19. Hence both Hiero and Dionysius I, discovered that a Sicilian empire must also control the toe of I taly.

20. This control of the necessary channel of trade, from which no doubt merchants suffered, is reflected in the tradition which represents Romulus' foundation as a Latin Cave of Adullam and describes how all the broken men flocked to join the robber band which founded Rome. (See Myres, Dawn of History, p. 235.)

21. The Roman constitution like the British is throughout a mass of constitutional fictions and never in fact corresponds to a paper scheme. Custom or the necessity of the moment determine where the actual power in the state resides. The creation by Augustus of an imperial autocrat, whose office in constitutional theory is nonexistent, is characteristic.

22. A really efficient but rigid machinery of government was established 
W. R. Halliday, The Growth of the City State, 48

under the Antonine emperors when a larger continuous area of the world was better governed than perhaps ever before or since. But its very excellence made it a contributor to the decline and fall of the Roman Empire. The overgovernment of an efficient centralised bureaucracy killed all local political life. Theconsequent devitalisation within assisted the barbarian pressure from without. The heavy burden of taxation ruthlessly increased to pay for the increasing cost of the civil service also played its part.

23. Vergil, Aeneid VI, 547-853, trans. Bowen. 
Lecture IV. The Growth of the City State.

We have no direct historical account of the growth of a city state. Scientific contemporary history begins in Greece with the Pel oponnesian War, in Rome with the second Punic War. Although Thucydides' short sketch of early Greek history reveals his mastery of historical method, the ancient historian was but little better equipped with material than the modern. Thesamehol ds good for thelater philosophers, who analysed the city state; nor indeed is a priori analysis reliable history. But, though much will always remain obscure and much completely dark, the main outlines of devel opment can be traced with fair certainty. It is clear that the constitutional devel opment of the Greeks and Romans had its origin in tribal institutions of very similar character. Pictures of the social organisation of the early Greeks are furnished by the Homeric poems. Constitutional survivals will sometimes throw light on thestructure from which they must have survived, just as a fossil bone may enable the paleontologist to reconstruct the anatomy of a prehistoric animal. Something may be learned also from analogy and the comparison of the institutions of other early societies. "Separate thy warriors by tribes and by brotherhoods, Agamemnon," says the wise old Nestor, "that brotherhood may give aid to brotherhood and tribe to tribe." The bond of early society both in peace and war was the bond of kinship strengthened by the bond of religion. The key to society in the heroic age was the clan, bound together by common descent from a divine ancestor and sharing a common worship and a common burial ground. A group of related gene, gentes or clans, made up a larger unit, the phratry, curia or brotherhood. The brotherhood too was united by the bond of a common cult, and upon the brotherhood in ancient Greece fell the onus of exacting vengeance for the murder of any of its members. The phyle, or tribe consisted of a group of brotherhoods again linked by kinship and religion.

Society was essentially aristocratic. In war "theyellow-haired tamers of horses" challenged each other to single combat, and the lesser crowd of 


\section{W. R. Halliday, The Growth of the City State, 50}

ill-armed dependents formed only a background to the duels of chieftains. In peace thestructure of society, which was patriarchal, placed the power and dignity in thehands of the heads of families, clans, brotherhoods, and tribes, in an ascending scale up to the king at the head of the community of several tribes. It was only the gods, and kings or nobles, their human representatives, who possessed private estates; the rest of the land was divided up among the families though, being the property of the family, it was administered by and was under the control of the head of the family, the pater familias. The whole organisation of society was in fact a survival from thekind of organisation called into existence by the needs of nomadic life, similar to that described in the Old Testament accounts of the wanderings of the Hebrew patriarchs.

Politically, this society is a monarchy, though al ready in the Homeric tradition the power of the king is largely limited by the prominence of the aristocracy. Agamemnon it is true is the head of a military confederacy, but in Ithaca, no less than in the camp before Troy, there are basileis besides the king who is but primus inter pares. His pre-eminence was due to his divine right and was therefore hereditary. But the case of Tel emachus shows that circumstances might arise in which it might be possible to set aside the hereditary claim in favour of one of the aristocracy who also claimed divine descent. ${ }^{2}$

The king led his people in war and it was naturally he who represented the people in their relations with the gods. ${ }^{3}$ The religious ceremonies of the community were his care and, long after the secular monarchy had disappeared in Greece and Rome, the older religious ceremonies were entrusted to an official named a king. The monarch also acted as arbitrator. Disputes were brought to him and hegave the decision. These decisions did not create precedents nor were they framed in accordance with any body of law. Dike or rightness guided the royal judge, but his decisions were binding in virtue of the king's divine authority of which the outward and visiblesymbol was the sceptre, itself often a magic wand of divine manufacture. "Most noble son of Atreus, Agamemnon, king of men, in thy name will I end and with thy name begin, because thou art king over many hosts and to thy hand Zeus hath entrusted the sceptre 


\section{W. R. Halliday, The Growth of the City State, 51}

and judgments, that thou mayest take counsel for the folk."

But already by the time that the passage describing the Shield of Achilles was written, the king was assisted in administering justice by the advice of the council of elders. Among the scenes depicted on the shield was a trial about the amount to be paid as blood-money for a murder. The award is to be decided by the arbitrator but his decision is guided by the opinions of the elders. The disputants are present in the market-place and the folk thronging round cheer now one side now the other as the points are made. "And heralds kept order among the folk while the elders on polished stones were sitting in the sacred circle and holding in their hands staves from the loud-voiced heralds. Then before the people they rose up and gave judgment each in turn."

Beside the Homeric and the early Roman kings stood the council of the elders which is here seen to be exerting an influence upon the king's powers of jurisdiction. In the lliad, a picture of an overseas campaign, all the members of this council are not old in fact, but their title is significant. They are al ways referred to as "the old men", and they meet at the ship of Nestor, to whose age and experience special weight is always attached. ${ }^{6}$ This body the king was expected to consult in all matters of policy and, in fact, would attach the greatest weight to its advice. It is this advisory council of theking, representing the collective experience of the community, which is the ancestor of the Gerousia at Sparta, the Council of the Areopagus at Athens, and the Senate at Rome.

In the direction of policy the people have little say. The assembly of the fighting men of the community is graphically depicted in the second book of the lliad. Matters are first discussed by the king and his council, their decisions are then announced to the somewhat disorderly "general meeting" of the fighting men. This assembly has no powers of deliberation; the attempt of Thersites to question royal policy is dealt with summarily. The maximum constitutional power possessed by the assembly is the signification of its assent or dissent by acclamation. ${ }^{7}$

In fact, both in Greeceand at Romethestructure of early society betrays its origin in a tribal organisation not dissimilar to that of the children of Abraham and Lot. Originally thetribewas bound together by kinship and 


\section{W. R. Halliday, The Growth of the City State, 52}

religion to form an exclusive social and political unit. The god belonged to the community, of which he was the ancestor, and like its human members was regarded as strictly within the tie of kinship. Rights, whether human or divine, were possessed only by members of the group of kinsmen and the avenging of murder within the community fell as a duty to the nearer kinsmen of the murdered man. Outside the tribal group killing was no murder, for the stranger being outside the community was therefore an outlaw. Hehad no rights of kinship or religion, and might therefore be killed with impunity.

It would appear, however, that before the invasion of the Balkan peninsula the $\mathrm{N}$ ortherners had al ready advanced beyond the purel y tribal stage of rigid exclusiveness. It is clear from the Homeric poems that the worship of Zeus, the father of gods and men, was common to the various sections of the invading peoples. This community of worship provided an invaluablesanction for the breaking down of the narrowly exclusiveview of tribal morality, a process which no doubt the necessities of political expediency must also have recommended. Already in the Homeric poems the stranger has acquired the right to equitable and merciful treatment. The universal worship of Zeus, the all-father, has brought all Greekspeaking men intoa common if remoterelationship, and thestranger and traveller are under his protection. The importance of the ethical and political advance upon the old tribal morality which this view implies is too obvious to demand elaboration. ${ }^{8}$

Heroic society was aristocratic in tone and, since property was held in common, it was an aristocracy of birth not an aristocracy of wealth. The divine descent of the noble showed itself in his greater prowess and his physically noblemien. "Even as a bull standeth out far foremost amid the herd, for he is pre-eminent among the pasturing kine, even such did Zeus make Atreides on that day, pre-eminent among many and chief among heroes." The disguised Athena is "delicate of countenance such as arethe sons of kings," and Thersites shows by contrast the characteristics by which nobility might be recognised at a glance. "And he was ill-favoured beyond all men that came to Ilion. Bandy-legged was he and lame of one foot and his two shoul ders rounded, arched down upon his chest, and over 


\section{W. R. Halliday, The Growth of the City State, 53}

them his head was warped and a scanty stubble sprouted on it. ${ }^{\prime \prime 9} \mathrm{~F}$ urther from the family, in which the pater familias has complete authority, upwards through the larger groups of kinship, the structure of society was monarchical in tendency.

This structure of society, which arose to meet the needs of a nomadic and pastoral people, was inevitably modified by adjustment to a settled and agricultural mode of life. Thucydides rightly emphasises the long period that must be postulated for the process of settling down. He sees the Trojan war as an interlude in this period of migration, which ended with the Dorian conquest of the Peloponnese. In its earlier stages the peoples are purely migratory. They are without commerce and their hold upon any territory is too precarious to permit of its being planted. A temporary crop is sown and harvested, and a new tribe descends to push out the first settlers. He notices that Greek traditions correspond with the deductions of the historian, in representing the richest territories as having been most frequently invaded, whilemaking aboriginal claims for the inhabitants of the poorer and more mountainous districts. Heis right too in remarking that the common name of Hellenes, which is unknown to Homer, is not due to unity of race nor to the political domination of a single tribe but to unity of language. ${ }^{10}$

Everywhere no doubt there was fusion, and different conditions produced different results in different places. The Macedonians remained unaffected by the normal course of development through which their kinsmen further south were to pass. They remained a tribal people under a monarchy of the epic pattern, and Alexander the Great, the cavalry leader at the head of his Companions, rightly looks back to his ancestor Achilles as his prototype. ${ }^{11}$ The Thessalians again, in the oneconsiderable plain of theBalkan peninsula, reduced the conquered inhabitants to serfs over whom they ruled as a horse-breeding aristocracy. The Dorians, too, both in the Peloponnese and in Crete, appear to have reduced the subject populations to the condition of slaves supporting and ruled over by a military caste who al one enjoyed political rights. ${ }^{12}$ Elsewhere the process of amalgamation is more evident than the subjection of part of the population leading to the creation of a slave class. 


\section{W. R. Halliday, The Growth of the City State, 54}

The wandering peoples settled first in unwalled village communities. Backward parts of Greece, like Aetolia, remained in this condition in historical times. ${ }^{13}$ Thetendency however of the villages in each geographical compartment shut off by the mountains was towards centralisation, primarily with a view to mutual defence against the raids of their neighbours. A natural strong placeliketheAcropolis in the plain of Attica or the Alban Mount in the Latin plain provided an almost impregnable site for the temple of the god, whose worship united the villages in a common bond, and a city of refugeto which his worshippers could at need retire for safety. Motives of convenience, particularly where the plain is of small area, will lead to the building of houses round the citadel, which is the original polis. ${ }^{14}$ As the settlement round this citadel develops, it will itself have a wall built round it and become a fortified town. ${ }^{15}$ The creation of cities took place under the monarchy and no doubt political motives assisted thepractical convenience of building thedwelling-houses under the protection of the shadow of the fortress. ${ }^{16}$ The king sought to concentrate his power over the villages of the neighbourhood by centralisation round the rock upon which his palace and the temple of the god were placed. To this process of centralisation the Greeks applied theterm synoi kismos, and it is important to notice that two different processes are included in the meaning of the word. It includes both a territorial concentration and al so a purely constitutional centralisation. Of the first type is the synoikism of Elis early in the fifth century, or the creation of the city state Megalopolis out of the Arcadian village communities by E paminondas in the fourth century. Here the inhabitants were removed from their villages and concentrated within the walls of a single city. ${ }^{17}$ It was in a similar way that city states came into being. In certain cases this local centralisation may be followed up by synoi kism in the second sense of purely constitutional concentration. Where the continuous area of the plain is sufficiently large more than one group of villages will probably be formed. The Boeotian plain is an example. Here a single state, Thebes, was strong enough to become a leading partner in a federation, but not strong enough to carry through complete centralisation of government. Attica, similarly, consisted of a considerable territorial area, in which 


\section{W. R. Halliday, The Growth of the City State, 55}

several independent combinations of villages arose. Here, however, the monarchy was sufficiently powerful to carry through synoikism, in the second sense of theword, and Theseus, according totradition, centralised the government of the whole of Attica in the town round the Acropolis. In other words the rulers of the community round the Acropolis were able to absorb politically the other communities in Attica. The inhabitants of the tetrapolis of Marathon, for example, were not thereby transported to live in Athens but they all became Athenians and subject to the central government in Athens. ${ }^{18}$

Although the ambitions of the monarchy promoted the concentration of society in cities, the effect of city life was to weaken the monarchy. As Herodotus noted in the case of Oriental monarchies the securest props of the divine right of kings are remoteness and unapproach-ability. ${ }^{19}$ Monarchy will al ways have a securer hold over nations than over smaller political units, and it is noteworthy that in the history of nations disaffection is more likely to arise in the capital and seat of government, in Paris or London, than in the country where traditional loyalty is not strained by the spectacle of the human weaknesses of the revered king. ${ }^{20}$ Already in Homer we have noticed the encroachments of the aristocracy. The nobles have followed the king to the town. The members of the council of the elders must of course have their houses there and, in general, the nobility will gravitate to the headquarters of government. Society is no longer in a normal state of war which demands a single war leader, and with the devel opment of city life its needs have become more complex. The single arbiter is no longer sufficient to fulfil them, and the increased duties of theking must be divided with supplementary officials in order to get the work done. Thus tradition credibly asserts that the institution of the ephors in Sparta was due to the necessity of providing magistrates to carry on the work at home during the absence of the kings in the Messenian wars. Though the monarchy at Sparta survived in form, these magistrates eventually obtained complete control of foreign affairs and reduced the royal power to a shadow. ${ }^{21}$ In Roman history, too, the number of magistrates tended to increase with the increasing demands of public business, a tendency of some constitutional importance, because 


\section{W. R. Halliday, The Growth of the City State, 56}

the increase in the number of magistrates automatically decreases the power and importance of each individual magistrate.

Gradual ly the monarchy was stifled by thearistocracy. Theking's power was put into commission and he was relieved of one function after another by magistrates. In Greece the process was gradual; in Rome it was carried through at a single revolution; in both the official, who in historical times preserved the royal title, of the royal functions retained only certain religious duties.

The new magistrates have not the same power as the king. Their power is limited in the first place because they have colleagues and divide the functions of the monarch with other magistrates, and secondly because their tenure of office is limited. In Greece this limitation of tenure seems to have been gradual. First magistrates are appointed for life, then for a period of ten years, and finally like the Athenian archons or the Roman consuls for one year. Both in Greece and at Rome the aristocratic council was recruited from theex-magistrates, who passed automatically intothe Areopagus or Senate after their year of office expired. It is important to realise the relative power in the state which this arrangement in fact gave to the aristocratic council. From the beginning it had been an influential body. The king was expected to take the opinion of the elders in all important matters and to pay attention to it when given. It was probably an attempt on the part of the Etruscan rulers of Rome to override the customary rights of the council, which led to the downfall of the monarchy in an aristocratic and national revolution. The new magistrates are less powerful than the king had been and they hol d office temporarily only, while the council is permanent. They will naturally consult the experienced and permanent element in the constitution, composed of persons who have themselves held office, whose ranks they will themselves join when their year of office is over. In practice the advice of such a body will have the force of a command, and the magistrate thus becomes the mere instrument for giving effect to the decisions of what is technically only his advisory council.

The basis of aristocratic rule lay in traditional respect. For a time it fulfilled the needs of a tribal and comparatively primitive society. If pride 


\section{W. R. Halliday, The Growth of the City State, 57}

of birth claimed for itself a leading position in thestate, it recognised al so that privilegeimplied obligation, and that thenoble's responsibility tothe state did not end with bearing the burden of cavalry service. It is to the credit of the aristocracies both in Greece and Rome that they built up a high ideal of public service in the interests of the state. They devel oped also a system of customary law. The primitive isolated judgments of the king (themistes) guided only by equity (dike) were developed into judgments given in accordancewith rules (nomoi) based upon precedent. ${ }^{22}$ It is true that the knowledge of these rules remained in the hands of their inventors and interpreters, i.e, the aristocracy. They were not yet published as a code nor revealed to the unprivileged classes, and the monopoly of knowledge of the secrets of the law is a monopoly liable to abuse. If for any reason the rule of the aristocracy falls out of harmony with the needs of the community, it is clear that their threatened position of privilege will be defended by their monopoly of the administration of secular law and their exclusive control, thanks to the tribal religious structure of society, of religious ritual. This latter is a strong weapon. In ancient religion, particularly in its more primitive stages, ritual has a prominent position. The relation of the community to its divine kin depends, not only on the observances being carried out but on their being carried out in devel oped. Private ownership of land was restricted to the demesnes (temene) set apart for the gods, the king, and the chi eftains. ${ }^{25}$ The remainder of the land, which was arable, was divided into lots (kleroi) and distributed among the various families, while the pasture became common land. ${ }^{26}$ Under the tribal system the land lots were held by the families but it was equally a necessary consequence of the patriarchal system that they were administered by the heads of the families. Use created the claims of ownership, and an inevitable result of local settlement on the land was the development of private property. Once the principle of private ownership was accepted, inequality of distribution followed as a matter of course. Primogeniture, the system under which estates are kept intact and pass to the el dest son, was not recognised in Greece, but the system of partition among the heirs leads equally to the same result. The dowry system and the marriage of 


\section{W. R. Halliday, The Growth of the City State, 58}

heiresses will tend to the concentration of land in a few hands, while the splitting up of landed property among numerous heirs will lead to the existence of holdings too small in area to be profitably farmed. ${ }^{27}$ In consequence, the owner will either sell his small holding to a rich neighbour who wants to round off his estate, or he will need to tide over the bad years by mortgaging the farm or his labour, thus falling gradually into the position of a serf of the rich creditor. There are also indications that the noble landl ords encroached upon the common lands, and that the landed interest abused its powers to its own advantage as it did in Great Britain during the period which saw the enclosure of the commons. ${ }^{28}$

The ninth and eighth centuries in Greece, which saw the concentration of landed property in the hands of the nobles, were a period of economic and social distress. The Hesi odic poems reflect plainly the feelings of the small farmer, who resented the corruption and injustice of the landowning squires and saw his own class being ruthlessly squeezed out of existence. ${ }^{29}$ I t had been an inevitable consequence of peaceful settlement that population increased. The amount of land, however, had remained necessarily the same and, even apart from the hardship of its unequal distribution there was now a surplus of mouths for which it no longer supplied sufficient food. The Greeks were in consequence driven to become sailors, and if the new development of commerce relieved the want of those who left the land for the sea, colonisation, which accompanied it, relieved to some extent the pressure of overpopulation. But both movements inevitably reacted upon the social and political conditions at home. For one thing commerce created a new class. The merchant, who abandoned poverty on the land for the adventure of maritime commerce, became, if successful, a wealthier man than his relations who had remained farmers. A new class thus comes into being whose wealth does not consist in landed property and whose members do not necessarily bel ong to the landed aristocracy. Tradition or sentiment are powerless to deprive commercial wealth of real importance in the community, and it is inevitable that the new class will demand some share at least in political privilegecorresponding toits importancein fact. The aristocracy may and do offer an obstinate resistance to any attempt to deprive them 


\section{W. R. Halliday, The Growth of the City State, 59}

of their political monopoly, but the power of the new class is bound in time to enforceits recognition. Obstinateresistance to its claims will only breed revolution.

Col onisation again will assist political unrest. Whatever the form of the constitution of the new colony, the reaction of the colonising movement upon the mother country is democratic in tendency. ${ }^{30}$ Persons, who are social and political nobodies at home, are known to have become people of importance in the new settlements. This raises, in concrete and individual examples, the question whether political ability is after all necessarily dependent on hereditary qualification as the aristocratic regime at home presupposes. The progress of commerce which attends and profoundly affects the character of colonisation, complicates matters still further by accentuating the economic dislocation of society and increasing the hardship of the small farmer. For with the development of commerce money becomes the medium of exchange. All large scale alterations in economic machinery, however beneficial in the long run, are bound to create temporary dislocation, just as in the Industrial Revolution the introduction of machinery involved the ruin of the small hand-working operatives. Thesmall farmer nolonger barters his produce direct for the commodities which he requires. He must now sell them for money and operate in a currency which he but partially understands. He gets into the hands of the middle-man and the aristocratic usurer, and sinks ever more desperately into debt.

There is yet another factor in the jarring discord of the times which deserves notice. The structure of society based upon kinship is entirely suited to nomadic conditions but, when once the nomadic state is abandoned, another element will cut across the bond of kinship and help to undermine it. In the ruthless age of iron the old patriarchal ties show signs of breaking up, and we may see the new principle of locality cutting across the old principle of kinship in Hesiod's advice to cultivate good terms with your neighbour. A good neighbour is a better friend, he says, than a relation. If you want help a neighbour will rush to your aid in his shirt-sleeves but a relation will stop to put on his coat. ${ }^{31}$ Already, in very early times, the principle of locality encroached upon the tribal principle 


\section{W. R. Halliday, The Growth of the City State, 60}

in matters of administration. The financial administration of Attica was very early organised in local units called naucraries, the exact functions of which are obscure in detail though it would seem that they formed the machinery for the raising of the necessary financial supplies for naval and military purposes. ${ }^{32}$

But though practical convenience led to the recognition of the local principle for the organisation of finance, the general social and political structure of society remained purely tribal. Now a feature of this tribal system is that it automatically excludes from participation in the state any person who is not by birth a member of a clan. Both in Greece and Rome, there emerge in consequence a class of minor dependents on the clans consisting of persons, who are not members by birth and do not share the full privileges of members, but by a form of adoption are put under the protection of some clan. In Rome the mode of adoption of a client by a patron takes a quasi-legal form; in Greece it took a religious form. It has been noticed that the family was bound by a common cult as well as by blood, and so integral a feature is the religious bond that Herodotus can say of an Athenian statesman, "I don't remember his geneal ogical tree but his relations worship Carian Zeus." ${ }^{13}$ The geneseem early to have consisted of two classes of members, homogalacteis (men of the same milk, i.e, members by blood) and orgeones (men who participate in thefamily ritual). These latter are members of a lower status who have been given a dependent claim upon the clan by religious adoption which makes them members of the family cult. The result of this rigidly tribal structure, which reserves full political rights to members by blood and a lower grade of civil protection to those for whom a fictitious family tie is created by adoption, is that "the impure by descent" (i.e., dependents dissatisfied with their modified status and those who are excluded entirely from political rights by not being members of a clan) form a discordant element in the state. The fact that from early times the financial administration of Athens was based upon a local and not a tribal unit is of some interest, because it supplied a model for the eventual solution of the problem of "the impure by descent" at Athens, when Cleisthenes dissociated the old family system from politics and substi- 


\section{W. R. Halliday, The Growth of the City State, 61}

tuted the principle of locality for the princi ple of kinship as the basis for determining political rights.

The eighth and seventh centuries saw the decay and fall of aristocracies in most of the Greek states. Thestrugglefor power between rival families was breaking up aristocracy from within, from without its prerogatives were challenged by the discontent produced by the economic distress of the poor, by the claims of wealth to political representation, and by the demands of the impure by descent for social and pol itical recognition. The result was the anarchy of warring factions and, when anarchy in a state has passed a certain point there is one solution, and one only, that will meet the situation. At all costs order must be restored under a strong central government and the factions reduced to the impotence and equality of a common servitude. J ust as the Wars of the Roses necessitated the strong rule of the Tudors and the excesses of the French Revolution led to military despotism, so the anarchy in the Greek states produced tyranny, and the creation of the empire was the necessary solution of the disorders which racked the Roman republic after thegreat wars.

The primary need of the states torn by faction was the restoration of some sort of order. The codification of the law and its publication, which was the first success won at the expense of aristocratic monopoly, though very definitely a victory of progress, did not really touch the diseases of the state. In almost all Greek states the revolutionary el ements eventually found a leader in a discontented aristocrat, or in one of the new commercial magnates who overthrew the rule of the nobles and utilised the forces of disorder to establish his personal authority by force ${ }^{34}$ To such autocracy created by force and supported by mercenary troops the Greeks gave the name of tyranny. The word tyrant, borrowed by the Greeks from Asia Minor, has passed into our language with an evil connotation which it did not originally possess. This colouring was given to the word by subsequent Greek reflection, and Greek historians and political thinkers have been less than just to the tyrant. This is due in part to the fact that early historical records consist chiefly of the traditions of the noble families, and these are naturally unfavourable to 


\section{W. R. Halliday, The Growth of the City State, 62}

the tyrants, whose main function it was to crush the power of the aristocracy. But the real cause lies deeper. The greatest of Greek contributions to political thought is the conception of the community as a living whole, of which its individual members are living parts. Law is the bond which unites them and regulates their relations to each other and to the community. Now autocracy is a direct negation of this fundamental conception of the nature of the state. The tyrant is an individual wielding arbitrary power based upon force and not upon law. I nasmuch ther eforeas heis irresponsibleand abovethelaw, he is outside the law, i.e, an outlaw. His government is primarily government in the interests of the ruler, not in the interests of the ruled. "Tyranny" says Aristotle "is just that arbitrary power of an individual which is responsibleto no oneand governs all al ike, whether equals or betters, with a view to its own advantage, not to that of its subjects and therefore against their will. No freeman, if he can escape from it, will endure such a government." ${ }^{135}$

We must admit the force of this criticism of tyranny and allow that, in its nature, arbitrary autocracy is a contradiction of the Western ideal of the true nature of political society, but that must not blind us to the facts that, in the first place, tyranny was a necessary stage in the devel opment of Greek constitutional history, and that, in the second place, the rule of the tyrants did in fact make direct contribution both to the welfare of the communities which they governed and to the progress of civilisation as a whole. Indeed the case of tyranny may suggest the relativity of political judgments and political theories tothecircumstances of their application. In practical politics theory has of necessity to be applied to facts, and the history of Greek constitutional development may suggest that forms of government cannot be judged only by their inherent and abstract merits and defects; they must also bejudged in relation to the social and political circumstances to which they are applied. F ailure to real ise this relativity lends a real danger to the tendency of political ideals to become political catchwords, i.e dogmas accepted by the inherent mental laziness of mankind as self-evident principles, whose merits are unconditioned by the nature of the facts to which they are to be applied. It may be admitted 


\section{W. R. Halliday, The Growth of the City State, 63}

for example that democratic self-government has in the abstract fewer inherent defects than other modes of government, but it by no means follows that democratic self-government is capable of immediate application to all and every political society in any stage of political education. National political independenceis, again, legitimately an ideal but, whether in a given case it is better that people should misgovern themselves or bemisgoverned by their own nationals, or begoverned well by an autocrat or by alien rulers is a problem upon which an opinion can only be formed after consideration of the attendant circumstances of fact. Cicero for example considered that the sacrifice of liberty was too great a price to pay for the possibility of good and efficient government. It would be difficult on the facts to adjudge his attitude politically sound. Tyrannies in the Greek states and the Roman imperial system at Rome were brought into being by a necessity, which set aside (temporarily in the first case) the ideal of independence. The continued existence of the political community demanded at all costs the restoration of order and the provision of efficient government, and this need could only be met by the concentration of political authority in the strong hands of a personal ruler.

Tyrannies then came into being in answer to a definite need, the need for the restoration of order in the state. It is primarily the tyrant's function to break the power of the aristocrats and the reactionary forces which are an obstacle to political development. Further this autocratic rule not only restores the order of unity but al so, by reducing the various elements in the state to the equality of servitude, prepares the way for democracy, ${ }^{36}$ while his own rise to power is a demonstration by example that military and political ability are not necessarily an inherited characteristic of a limited aristocratic caste.

The tyrant's position is dependent upon his personality, and no force of mercenaries or spies will protect him from the assassin's dagger or the pressure of public opinion if the populace are not kept contented and occupied. In fact the selfish interest of the ruler and the interests of the ruled here coincide, for efficient government is a condition of thetyrant's permanence; his arbitrary position can only be justified by success. It is 


\section{W. R. Halliday, The Growth of the City State, 64}

a natural consequence that both the domestic and foreign policy of the tyrants promotethe material progress of their states. An energetic policy abroad fosters national sentiment at home, and international success distracts the minds of their subjects from real political servitude by the glamour of national expansion. The tyrants also promote colonisation, which provides incidentally a safety-valve by which dangerous rivals may be removed with honour to a safe distance. Their colonisation, too, is planned more definitely on national and imperial lines with the object of getting control of the commercial trade routes and securing the international interests of the state. ${ }^{37}$

In domestic policy the welfare of the previously oppressed classes, with whose hel p the throne was won, is naturally promoted. In some states of the Pel oponnese where the discord of classes had been complicated by the existence of more than one racial element, a feature of the tyrant's policy was the rehabilitation of the subject nationality at the expense of the previously dominant race. In general, since a contented proletariat is a condition of the tyrant's tenure of power, the material well-being of the poorer elements will be his especial care. Land reform will be financed, roads and works of public utility constructed. The Athenian farmer of later periods looked back to Peisistratus' reign as the age of gold. ${ }^{38}$

Magnificent public works, including the temples and buildings with which he adorned his capital, provided both an expression of, and a stimulus to the feeling of national pride, which it was the tyrant's business to cultivate, while the concentration of capital in the hands of a single administrator and the slave labour provided by successful wars enabled material prosperity to be financed and permitted the subsidising

of art upon a large scale. ${ }^{39}$ Athens, the tyrant state, under Pericles, the second Peisistratus, was but true to type in spending the spoils of empire on the artistic expression of patriotic pride. ${ }^{40}$

Whatever may bethe objections to tyranny as a form of government, the debt of civilisation to tyrants is not small. We have only to think of the architectural discoveries of Corinth under the Cypselids, ${ }^{41}$ of the canal at Leucas or of that planned though not completed across the Isthmus of Corinth, ${ }^{42}$ of the three wonders of Polycratean Samos, ${ }^{43}$ of the Athenian 


\section{W. R. Halliday, The Growth of the City State, 65}

temples and aqueducts, ${ }^{44}$ or of the system of land banks by which Peisistratus gave reality to the agricultural reforms inaugurated by Solon. ${ }^{45}$ In the realm of art and science we have the development of dithyrambic poetry at Corinth, ${ }^{46}$ Democedes the physi cian and Anacreon the poet at the court of Polycrates, ${ }^{47}$ Pindar and Bacchylides at Syracuse, the sculpture of Peisistratean Athens. ${ }^{48}$

In religious matters the rule of the tyrants gave an important impetus to Panhellenic tendencies. Aristotle remarks that a ruler "should appear to be particularly earnest in the service of the gods; for if men think that a ruler is religious and has a reverence for the gods, they are less afraid of suffering injustice at his hands and they are less disposed to conspire against him because they believe him to have the very gods fighting on his side." ${ }^{\prime 9}$ The tyrant has not, like the noble, the sanction of divine descent and precisely because he has no legitimate claim to his position he will endeavour to obtain the support of Heaven. His first political necessity has been to destroy the power of the noble families. He will in consequence wage a ruthless warfare not only upon their material but also upon their spiritual prerogatives, for the political strength of the aristocrats lies largely in their monopoly of the tribal cults. ${ }^{50}$

Now an obvious weapon against the particularist cults is theencouragement of the worship of Panhellenic at the expense of local deities, and it is in consequence the age of the tyrants which sees the rapid devel opment and propagation of the worship of Dionysus, Zeus and the gods of the Homeric pantheon. A concomitant result of this religious trend is the increase in number and importance of the Panhellenic games. The Pythian, I sthmian and Nemean games wereall instituted in thefirst half of the sixth century. Even to-day a King's Derby is a popular event and the number of Pindar's royal patrons is witness to the political significance which the Panhellenic festivals possessed for tyranny.

The Panhellenic tendency of religion further increased the political power and prestige of the Del phic oracle, the great Panhellenic centre of religion. ${ }^{51}$ Already it enjoyed political importance as the central intelligence bureau for intending colonisers and it was natural that, with the new emphasis laid upon foreign policy and the shifting of interest from 
W. R. Halliday, The Growth of the City State, 66

parochial faction to international affairs, Del phi should play an important political role. Quite apart from the oracles to Cypselus or Cylon, the enrolment of Periander among the Seven Sages, or the innumerable dedications of grateful tyrants in the temple treasuries, it is clear that considerable influence was exercised from Del phi upon the foreign policy of individual Greek states. ${ }^{52}$

Tyranny as a normal mode of government was short-lived in Greece. It had come into being to meet a definite necessity; when that need had been met tyranny fell. At Sicyon the dynasty of Orthagoras lasted 100 years; in no other Greek state did autocracy endure so long. The immediate occasion of the fall of tyrannies in the Peloponnese was affected by an external cause in the ambition of Sparta, who, by adopting the role of the Dorian liberator from I onian tyrants, furthered her project of herself becoming the dominant partner in a Pel oponnesi an confederacy. The cause of their fall however was deeper, more universal and inevitable. Tyranny in itself was a contradiction of the Greek ideal of the state and the moral forces against it were too strong for its indefinite continuance. And if monarchy had been doomed by the small size and intense political activity of the city state, tyranny, which had not even the constitutional and semi-religi ous sanctions of the heroicmonarchy, could not hope to survive. Both in origin and tenure its authority was based upon force and its most sure foundation was the personal ity of the ruler. If aristocracies as a whole degenerate, but sel dom are qual ities transmitted unimpaired within the limits of a single family. In proportion as his personality is weaker the successor of the founder relies more and more upon force; a Gelo is succeeded by a Hiero, a Peisistratus by a Hippias. ${ }^{53}$ A conspiracy is formed; it may be unsuccessful but the tyrant's nerve is shattered; a reign of terror follows with its attendant spies and informers, until at length the assassin's dagger cuts short thetyrant's life or popular exasperation drives him out.

It has been said that tyranny prepared the way for democracy. It is not true however that in every Greek state the rule of the tyrant was succeeded by the rule of the people. I n somestates like Corinth, the great commercial city, a mercantile plutocracy ruled and ruled satisfactorily; 


\section{W. R. Halliday, The Growth of the City State, 67}

in many the principle of "the stake in the country" determined the position of political authority in the community. Further, external influences moreand more complicateand affect the internal constitutions of the Greek states. It is an inevitable result of their emergence under the tyrants to an international status, that constitutional development no longer follows an undisturbed course, separate though parallel, in the individual states. Sparta in the Peloponnese had posed as the liberator, and it suited Spartan interests that the members of her league should be ruled by their conservative elements. Athens, who created a maritime empire after the Persian war, preferred in her subject states a constitution in harmony with her own democracy. ${ }^{54}$

But although the fall of the tyrants did not result in a uniform type of constitution universally adopted, it is important to realise that the struggle between oligarchy and democracy in the fifth and fourth centuries is not a renewal of the old faction to which the tyrants had put an end. Whatever use may be made of the old catchwords and of appeals to the "constitution of our fathers," the struggle in fact is new and different in character. Fundamentally it is no longer a struggle between privileged and unprivileged cl asses but between rich and poor, or between themiddle-class landowner and theurban prol etariat. ${ }^{55} \mathrm{This} \mathrm{struggle,} \mathrm{the}$ ultimatebasis of which is economic, became universal in the Greek world, and the balance in the individual states was swayed by their foreign politics and their di plomatic relation towards thetwogreat powers, which eventually divided Greece into two opposing camps. With Athens will be ranged the democracies and in the states subject to Athens the democratic faction can rely upon Athenian support. Similarly the tone of the Peloponnesian league will be conservative and Sparta will exercise her influence to maintain the political power in the hands of the upper class. States like Megara, which are bones of contention between the two will be torn by internal faction coincident with the external forces at work. The change from Spartan to Athenian control is accompanied by a democratic revolution; with her return to the Peloponnesian league "the few" once more become the masters of the state. 
W. R. Halliday, The Growth of the City State, 68

Notes to Lecture IV.

1. Iliad II, 362.

2. The basileis of Hesiod are not kings but land-owning barons. The royal title as applied to the aristocracy survived in the Athenian head of a tribe who was called phylobasileus. Thucydides describes the heroic monarchy as being hereditary with fixed prerogatives (Thucydides I, 13, cf. Aristotle, Politics III , 14, 1285 b.). For the case of Telemachus see Odyssey I, 383 foll. Antinous admits that Telemachus has an hereditary claim (ib., l, 387).

3. E.g., Iliad II , 402, Odyssey XIII, 181. Aristotle says that the king was a general and a judge and had the control of religion; the kings presided over sacrifices except those which required a priest (Politics III , 14, 12-14, 1285b.). Thetribal and family cults of course remained in the jeal ous hands of the aristocracy. The king directs the national ritual. Here his only rival is the professional seer and there is indication of friction between Agamemnon and Calchas (Iliad I, 106) comparableto that between Saul and Samuel (I Samuel viii, 4; xii, 12; xiii, 8-14).

4. Iliad, IX, 96. Agamemnon's sceptre was made by Hephaistos, who gave it to Zeus. Zeus gave it to Hermes who gave it to Pelops and from him it passed down the royal line of Argos (Iliad II, 100). It is handed to Odysseus as a symbol of authority for rallying the Achaeans (I liad II, 186). The royal wand of authority and the magician's or poet's wand of power are perhaps connected in origin. Lituus was used by the Romans both for sceptre and also for the wand used in augury for delimiting the quarters of heaven (Servius ad Aeneid VII, 187). Sceptre is of course used poetically as a synonym of royal power, eg., Euripides, I phigenia in Tauris, 187. For the worship of "the sceptre of Agamemnon" at Chaeronea see Pausanias IX, 40, with F razer's note. 5. Iliad XVIII , 497 foll. The scene of the el ders sitting in the sacred circle will remind the reader of Plutarch of that other picture of the ring of Roman senators in the forum seated in calm dignity upon their chairs of office awaiting their doom at the hands of the Gallic savages (Plutarch, Lift of Camillus, 22). It would appear from I liad I , 238 that 


\section{W. R. Halliday, The Growth of the City State, 69}

the barons were already encroaching upon the king's rights as sole arbitrator. After theformation of cities local considerations must have increased this tendency. A Hesiod will not want to go to the city to get his dispute settled; it will be quicker to get it settled by the squire.

6. "But first the council of the great hearted elders met beside the ship of Nestor, the Pylos born." (Iliad II, 54.)

7. See the description of the meetings in Iliad II, 86 foll. and II, 142. The assembly signifies its assent by acclamation. "So spake he and the Argives shouted al oud like to a wave on a steep shore when the South Wind cometh and stirreth it" (ib., II, 394). In historical times the Spartan Apella or popular assembly voted by acclamation "by shouting not by vote" (Thucydides I, 87), a method which, as applied to the election of magistrates, Aristotle brands as childish. (Politics II, 9, $1270 b$ and 1271a.)

8. "Nay, lord, have regard to the gods for we are thy suppliants; and Zeus is the avenger of suppliants and sojourners, Zeus, the god of the stranger, who fareth in the company of reverend strangers." (Odyssey IX, 270, cf. Odyssey, VIII, 546, VI, 207, XIV, 58.) For the ethical development of this belief see Plato, Laws $V, 729-730$.

9. IIiad II , 480, Odyssey XIII, 222, IIiad II , 216. Aristocratic lineage can be recognised at once. "T aste ye food and be glad and thereafter when ye have supped we will ask what men ye are; for the blood of your parents is not lost in you but ye are of the line of men that are sceptred kings, the fosterlings of Zeus; for no churl could beget sons like you" (Odyssey IV, 60, cf. Odyssey I, 222, I , 411). Moral qualities are transmitted with the physical. "Therefore ye could not say that I am weak and a coward by lineage and so dishonour my spoken word" (Iliad XIV, 126). Nobility is defined by Aristotle as inherited virtue (arete) and wealth (Politics IV , 8, 1294a, cf. ib., V, I, 1301b). Plato too was strongly influenced by the belief that both moral and physical qualities are hereditary; a king's son will be royal, a good man's son a good man, a beautiful man's son beautiful and so on (Cratippus, 395 A).

Noble families in Greece as in Rome claimed divine descent and the noble 


\section{W. R. Halliday, The Growth of the City State, 70}

was of the seed of Zeus (I liad I, 337, XI , 822, Odyssey II, 352, 366, cf. Euripides, Medea 827, Aeschylus, Niobe, Frag. 162). Wilamowitz points out that under the democracy all Athenians are equal, all "earthborn", and therefore of divine descent, but that should not deceive us as to the fact that once the sons of the gods proudly looked down upon the terrae filii, as the Romans always did (Wilamowitz, Aristotel es und Athen II, p. 50; for terraefilius of. Cicero, ad Att. I, 13, 4). The doctrine of divine descent of the aristocracy with its corollary of inherited physical and moral excellence affected political vocabulary. The aristocrats are the "notables" ( $\gamma v \omega$ ต $\mu \nu \mathrm{o})$, the "good men and

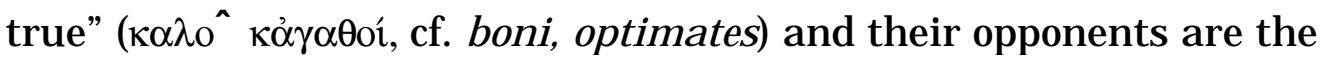

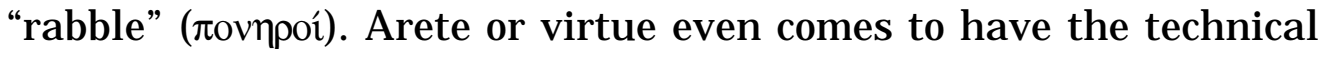
meaning of virtu in the sense given to the word during the Italian Renaissance, and it denotes political ability rather than moral quality. Thus Thucydides describes Antiphon as "second to none of his

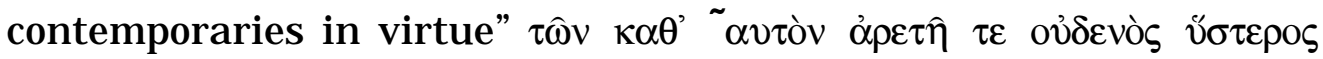
(Thucydides VIII, 68).

See further Bury, Ancient Historians, p. 144.

The aristocratic tradition also affected the Greek attitude of contempt towards trade, which was in part a survival from the prejudice of a military aristocracy (cf. Herodotus II, 167).

10. Thucydides I, 2 foll. He represents the early settlers as not planting

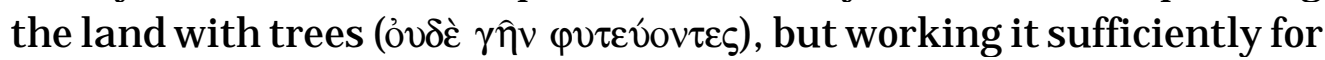
bare needs. Climatic conditions make temporary crops possible and the Greek farmer, unl ikethel talian, is not occupied all theyear round (see Myres, The Dawn of History, p. 223). For the temporary crop compare Herodotus' account of the circumnavigation of Africa by the Phoenicians, who solved the problem of commissariat by sowing temporary crops from timetotimeand waiting until they ripened. The voyage took two years. (Herodotus IV , 42.) F or the general conditions of settlement during the disturbances of migrations see Miss N ewbiggin's remarks on the result in Spain of nomadic invasion from Africa. "A stable civilisation must always be based upon agriculture, but every disturbance of an old and stable civilisation has temporarily 


\section{W. R. Halliday, The Growth of the City State, 71}

encouraged the pastoral as contrasted with the agricultural industries" (Newbiggin, Modern Geography, pp. 179-181). She also draws attention to the fact that unity of language does not necessarily correspond with unity of race (ib. p. 213 foll.); for the relation between the Greek language and racial homogeneity see Bury, History of Greece, p. 40.

11. "Myrmidons, ye comrades of Achilles, son of Peleus, be men, my friends, and be mindful of your impetuous valour so that we may win honour for the son of Peleus, that is bravest of the Argives by the ships and whose close-fighting squires are the best" (Iliad XVI, 269 foll., cf. Iliad IV, 266).

12. In Laconia there would seem to have been a double process of amalgamation and conquest. Very probably two conquests are involved. In the first the Dorians would seem to have amalgamated with the conquered, and the senior royal house of Sparta claimed Achaean descent. "The dwellers round" (Perioeci), who may represent the fusion of the earlier conquest, enjoyed under the second a considerable degree of autonomy but no political powers in the Spartan state. These were reserved for the military caste of Spartiates. Besides the "dwellers round" there were the Helots, who were definitely a serf class, and were probably reduced to that condition by conquest. When the need for further land allotments forced Sparta to cross Taygetus and conquer the Messenian Plain it was to the condition of Helots that the native population was reduced.

In the other Dorian states of the Pel oponnese the conquered population seems originally to have been reduced to the status of agricultural serfs who wereknown by contemptuous nicknames derived from their appearance, dress, or military status. Thus they were called $\gamma v \mu \nu \eta \tau \varepsilon \varsigma$ at Argos and корurnчopor at Corinth because they did not serve in the heavy armed citizen infantry, "dusty feet" at E pidaurus, кvvóp $\alpha \lambda$ or at

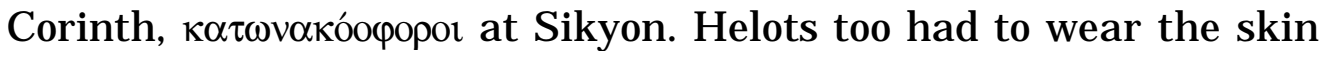
cap, which had been worn by Homeric peasants (Od. XXIV, 231), and garment of raw hide (Athenaeus XIV, 74, 657D). I $n$ all the Pel oponnesian states however, except Sparta, the non-Dorian el ement eventu- 


\section{W. R. Halliday, The Growth of the City State, 72}

ally acquired political rights, and it is usual to find a fourth nonDorian tribe in addition to the three tribes, Hylleis, Pamphyloi and Dymanes, into which the Dorians, wherever they are found, are regularly divided. At Argos there seems to have been a class intermediate between the Dorian rulers and the serfs, which corresponded to the Laconian Perioeci. Whether or not this was universally therule in the Dorian states of the Peloponnese there is not sufficient evidence to determine.

13. Thucydides III, 94, I, 5, cf. Ozolian Locrians, ib. III, 97.

14. Thucydides II, 15, 3. Polis remained the official name for the Acropolis at Athens as is shown by inscriptions, eg. Hicks and Hill, Greek Historical Inscriptions, No. 49, cf. Aristophanes, Clouds, 69.

15. The exception is Sparta which remained an aggregate of unfortified villages. Owing tothe military superiority of her fighting army Sparta had no need of fortifications (Thucydides I,10, I, 90). This superiority was due not merely to the better training of the individual hoplite, but also to the organisation of the army into a regular series of tactical units of manoeuvre (see Thucydides, $V, 68$ ).

16. Compare in historical times the policy pursued by the Sicilian tyrants of concentrating population in their capital, Syracuse (Herodotus, VII, 156, Diodorus XI, 72).

17. Previous to $471 / 70$ the Eleians were organised in districts ( $\delta \hat{\eta} \mu о \imath)$, (see Hicks and Hill, No. 9). They were then removed from their villages and concentrated within the walls of a single town (Diodorus XI, 54, Strabo VIII , 3, 2, 336). Another good example of synoikism in the local sense is Olynthus. Perdiccas, the king of Macedon, persuaded the Chalcidians toleavetheir towns on the coast, which were at the mercy of Athenian naval power, and concentrate in a single strong city (Thucydides, I, 58). The converse is the punishment of Mantinea by Sparta in 385 B.C., when the town walls were destroyed and the city split up into its constituent villages (Xenophon, Hellenica V, 2, 7).

18. Thucydides II , 15, 2.

19. See Herodotus' story of the rise of the Median Dei okes to power. After concentrating his subjects in a single town dominated by his citadel, 


\section{W. R. Halliday, The Growth of the City State, 73}

he made himself difficult of access and cultivated a mysterious al oofness shrouded in oriental ceremonial (Herodotus I, 96-99).

20. Warde Fowler, City State, pp. 90-91.

21. Plutarch, Cleomenes, 10, Greenidge, Handbook of Greek Constitutional History, pp. 103 foll.

22. The word \{vómos\} is relatively late. It does not occur in Homer at all and is first found in Hesiod in the sense of "rule" eg., this is the best rule for ploughing. The history of the word is discussed in Pearson, Verbal Scholarship and the Growth of some Abstract Terms, p. 35.

23. "Cyrnus, the city indeed is still the same city but the people are different who before knew neither verdicts nor laws but about their flanks wore off the hair of goat-skins and pastured like stags without the city walls. And now they are "the good," son of Polypais; and those who before were noble now are mean. Who could endure to behold this?" (Theognis I, 53.) "The good, my Cyrnus, never yet brought a state to ruin," etc. (ib. 43). Cf. Theognis I, 183 foll, on aristocratic mesalliance. Care is taken to breed animals from a thoroughbred stock and yet the nobility nowadays thinks nothing of intermarriage with rich commercial families. This analogy of the studfarm later supplies the Greek philosophers with their usual line of approach to the problems of heredity.

24. Herodotus V, 92.

25. Iliad XVIII, 550.

26. The land which was worthless for anything but pasture was open to anyone to use but it belonged to the state, and when the value of marble and metals was discovered, the quarrying and mining rights were state property (see Wilamowitz, Aristoteles und Athen, II , 47).

27. F or the division of property among children see the Laws of Gortyna, the earliest Greek code which we possess; text translation and notes will befound in Dareste, Recueil des I nscriptions] uridiques Grecques, I, pp. 352 foll. Hesiod recommends small families for economic reasons. "May there be an only born son to feed his father's house; for so is weal th increased in the halls. But late bethy death if thou leave a second son" (Works and Days, 376). If Plutarch may be trusted, the 


\section{W. R. Halliday, The Growth of the City State, 74}

right of freetestamentary disposition of property was first introduced at Athens by Solon (Plutarch, Solon, 21), though it was restricted to the childless. Under Solon's laws legitimate sons succeeded to the estate. A daughter, if there were no sons, inherited and if there were sons, she had a claim on the estate for her dowry. Illegitimate sons could not succeed, though they might receive a legacy not exceeding 1,000 drachmae. (Aristophanes, Birds, 1653-1661 with Rogers' notes.) Heiresses, in early Greek law, were compelled to marry inside the family. The Laws of Gortyna make a concession by allowing the heiress, if she objects to marriage with the appointed relative, to buy her freedom by surrender of part of the property. The result of the dowry and heiress systems may be seen at Sparta, where, early in the fourth century B.C., a law was passed allowing the disposal by sale or testament of the Spartiates' land-lots, which had previously been inalienable. Aristotle tells us that as a result "nearly two-fifths of the land are held by women; this is owing to the number of heiresses and to the big dowries which are customary" (Politics II, 9, 1270a). In modern Greece, where the dowry system prevails, the same tendency may be seen at work. In some of the islands practically all real estate is the property of women.

28. For the Athenian hektemoroi and small-holders who had become slaves see below, p. 185. In early classical society the debtor's person was the ultimate security upon which his creditor could distrain, cf. Laws of Gortyna, Hicks and Hill, No. 35. It is difficult to be sure what is meant by the "pillars" in Solon's poem. "Dark Earth, thou best can witness from whose breast I swept the pillars broad-cast planted there" (Aristotle, Athenaion Politeia, 12, trans. Kenyon). I have preferred Rev. E. M. Walker's explanation that boundary stones rather than mortgage pillars are meant; there is not, I think, any evidence earlier than the fourth century for the latter sense of the word. Mr. Walker suggests that the nobles had pushed forward their boundary stones and encroached upon the common land, and that it was these symbols of encroachment which Solon removed.

29. "F or now verily is a race of I ron. Neither by day shall they ever cease 


\section{W. R. Halliday, The Growth of the City State, 75}

from wasting and sorecares shall the gods givethem, etc." (Works and Days, 176).

30. Normally col onies formed an aristocracy of first settlement. Compare the social pretensions of the old Dutch families in New York. The democratic influence of thecol onisation movement was not dependent upon the form of constitution adopted by the col ony.

31. Hesiod, Works and Days, 182 notes the break up of patriarchal ties. "F ather shall not belike to his children, neither the children like unto the father; neither shall guest to host, nor friend to friend, nor brother to brother be dear as aforetime." The advice about neighbours is given ib. 341 foll.

32. Similarly the Roman tribes, which after the Servian reform supplied the machinery for the collection of the war tax (tributum), were local divisions, a fact of some importance when they became the basis al so of a popular assembly, Comitia Tributa. No doubt the local principle is the most obviously convenient method of arranging a permanent system of taxation, while land was of course the principal form of wealth.

33. Herodotus V, 66.

34. "A tyrant is chosen from the people to be their protector against the nobles in order to prevent them from being injured. History shows that al most all tyrants have been demagogues, who gained the favour of the people by their accusation of the nobles" (Aristotle, Politics V, 10, 1310b; cf. V, 5, 6, 1305a). In a few cases the factions in the state endeavoured to forestall revolution by the appointment by common consent of a single person with a limited tenure of supreme authority for the adjustment of the claims of conflicting parties. Such a magistrate was called aesymnete and held office either for life, or for a fixed term, or until certain duties had been performed. His office is described by Aristotle as an "elective tyranny." Like the tyrant's, his authority was supreme, but, although he might be given a bodyguard, it was based not upon military force but upon popular consent (Aristotle, Politics III , 14, 8, 1285a, III, 15, 16, 1286b, IV , 10, 1295a; Greenidge, Handbook of Greek Constitutional History, p. 27). Of this 


\section{W. R. Halliday, The Growth of the City State, 76}

character were Pittacus of Mytilene and Zaleucus and Charondas, the constitution makers of Western Hellenism. The only constitutional dictator of whom we have detailed knowledge is Solon of Athens. In his case, as we shall see, faction had gone too far for moderate reform; no party was content with a compromise; the nature of the disease demanded surgical not palliative treatment, and tyranny was only postponed.

In some cases tyranny established itself not by a coup d'état but by the extensi on of an existing magistracy, eg., at Miletus (Aristotle, Politics $V, 5,8,1305 a)$. Thus at Athens in 582 Damasias attempted to hold the archonship continuously, remaining in office for two years but being expelled in the third. We may compare the tendency in the later history of the Roman Republic to over-ride the annual tenure of the magistracy. The continuous tribunate of Gaius Gracchus, the continuous consul ship of Marius, the extended tenure of extraordinary foreign commands culminating in Pompey's rule of Spain by legati, while himself remaining in Rome, are precursors of autocracy.

35. Aristotle, Politics IV , 10, 4, 1295a. For the influence of aristocratic traditions upon the historical representation of tyrants compare the stories of Herodotus about the great house of Cypsel us at Corinth. No doubt the attitude of Herodotus, which sometimes affects his political judgment, is coloured partly by the association of tyranny with Oriental despotism, owing to the reappearance of Hippias at Marathon and al so tothe fact that the states of Asia Minor subject to Persia werenormal ly governed through tyrants. For this latter system Persia was not in fact to blame. Cyrus found tyrannies al ready in existence and did not impose them upon his Greek subjects and although the system of government through the personal responsibility of a subordinate ruler was practically convenient and congenial to the general character of Persian imperialism, Persia proved herself quite willing to acquiescein the substitution of democracies after thel onian Revolt.

36. The same forces on an extended and more complicated scale may be observed at work in English history. The Wars of the Roses led to the 


\section{W. R. Halliday, The Growth of the City State, 77}

strong rule of the Tudors who restored order and unity, broke the power of the barons, and inaugurated a period of national development and expansion. They noless prepared the way for the democratic movement of which the political symptom was the Great Rebellion.

37. E.g. the foreign and colonial policy of the Cypselids which aimed primarily at controlling the western trade route, or that of Peisistratus who sought to establish Athenian control on the Hellespont (Sigeum and Chersonese) and Athenian influence in the Cyclades (restoration of the Delian F estival and support of Lygdamis of Naxos). For the difference between the earlier phase of colonisation inspired by land-hunger in which the sites were chosen primarily on account of agricultural possibilities (eg. Chal cedon instead of Byzantium), and the later phase inspired and consciousl y directed by the desire to gain markets or to control trade, see Gwynn, "The Character of Greek Colonisation,"J ournal of Hellenic Studies, XXXVIII, pp. 88 foll.

38. Aristotle, Atbenaion Politeia, 16.

39. Thus for example the spoils of Himera financed the public works at Acragas and Syracuse while the captives supplied the labour ( $\mathrm{Hill}$, Sources for Greek History, p. 331).

40. Pericles the second Peisistratus (Plutarch, Pericles 7). For the building policy of imperial Athens (Plutarch, Pericles 12). See further references in Hill, Sources, pp. 187 foil.

41. Pindar, Olympian XIII, 21.

42. Canal at Leucas (Strabo, X, 2, 8, 452); projected across Isthmus (Diogenes Laertius I, 99).

43. Herodotus III, 60. Cf. Aristotle, Politics, V, n, 1313b.

44. See How and Wells, Commentary on Herodotus II, p. 343.

45. Aristotle, Ath. Pol. 16.

46. Herodotus I, 23, Pindar, Olympian XIII, 19.

47. Democedes, Herodotus III, 131; Anacreon, Herodotus III, 121.

48. To this period belong the sculptures of the pre-Persian temple on the Acropolis and the beautiful series of archaic figures of maidens (see Gardner, Handbook of Greek Sculpture, p. 164. Dickins, Catal ogue of the Acropolis Museum I). 


\section{W. R. Halliday, The Growth of the City State, 78}

49. Aristotle, Politics V, II, 1315a; cf. the story of Peisistratus and Athena.

50. Somewhat similar was the motive of Cleisthenes, the lonian tyrant of Sicyon, in suppressing the cult of the Dorian hero, Adrastus. Herodotus $\mathrm{V}, 67$. The political importance of the control of religious cults by the aristocracy is further shown by the action of his namesake Cleisthenes, the founder of Athenian democracy. In carrying out his work of destroying the tribal structure of political society, he found it necessary to create local (deme) cults to take the place, for political purposes, of the old family cults.

51. Plato, Republic, 427 B. See Dempsey, The Delphic Oracle, p. 112.

52. See the references in Dempsey, op. cit., pp. 91 foll. His treatment however of the relation between the tyrants and Delphi is not al together satisfactory. Foreign powers found it worth while to keep on good terms with Delphi. This was the policy of the Lydian kings from Gyges (Herodotus I, 13) down to Alyattes and Croesus (Herodotus I, 25, I, 50 foll). Similarly after the disastrous fire of 548 B.C. Amasis the king of Egypt contributed 1,000 lbs. of alum towards rebuilding the shrine (Herodotus II, 180). The kind of way in which the strings of foreign policy were pulled from Del phi, is shown in the story of the war between Alyattes and Miletus and the part played by Del phi and Periander in the settlement (Herodotus I, 19, 22).

53. Gelo walked the streets unarmed and after Himera particularly became a popular hero both in life and in death. The weaker Hiero was dependent upon his police system to maintain his position. (See the passages collected in Hill, Sources for Greek History, B.C. 478-431, pp. 312-314, 332.) Compare the mild Cypselus (Aristotle, Politics, 1315b) with the tyrannical Periander (Herodotus V, 92, Aristotle, Politics, 1284a, 1311a, 1313a). The historical tradition lays stress upon the democratic mildness of the government of Peisistratus (Thucydides VI , 54; cf. the story in Aristotle, Politics V, 12, 2, 1315b).

54. E.g., the case of Erythrae, where Athens took advantage of political faction to set up a democratic constitution, the inauguration of which was conducted by Athenian civil commissioners (episkopol) and the 
W. R. Halliday, The Growth of the City State, 79

officer commanding the Athenian garrison. (Hicks and Hill, No. 32.) 55. The change in the character of the internal political rivalry in Greek states is comparable to the change in the character of the parties in the Later Roman Republicfrom theOrders whosestruggleis themain theme of her earlier constitutional history. 
Lecture V. The Early Constitutional Development of Athens.

Our survey of the normal development of the city state will have suggested that the change from a tribal form of society to that of a civilised local political community will inevitably raise two problems, which will imperiously demand solution: (1) the satisfaction of the claim of wealth to political representation, (2) the claim of persons who are "impure by descent" for whom there is no place in a society, which is organised solely on a basis of kinship, to become members of the body politic. We may now compare the early constitutional development of Athens and Rome with the normal development, which we have traced, and notice how these two problems affected their respective histories.

There is evidence that Attica in early days contained a number of communities consisting of groups of villages united by a common worship, which were politically independent and often at war with one another. ${ }^{1}$ It is probable, indeed, that the Acropolis itself changed hands more than once, but Athena, the goddess of the olive, eventually triumphed over Poseidon, and the worshippers of the goddess not only established their hold upon the fortress but gradually absorbed the other communities.

The Greeks, following a natural tendency of tradition, ascribed this process to the action of a single strong ruler, Theseus, who dissolved the local governments and centralised the government of the whole of Attica at Athens. ${ }^{2}$ More probably the process was in fact gradual and the conquest of Eleusis by Athens which tradition has recorded, was the last event in a long series. ${ }^{3}$

In Attica as elsewhere the monarchy fell before the aristocracy. The king's office was put into commission and the predominant power in the state passed into the hands of the aristocratic council. Attica in fact passed through those phases of constitutional development, which we have discussed as representing the normal political evolution of the Greek city state. In one important respect, however, there is a distinction to be noticed. Her rate of devel opment was slower, and the various stages 


\section{W. R. Halliday, The Growth of the City State, 81}

were reached at a later date than in most other Greek states; tyranny for instance was established in Athens in the middle of the sixth century, a hundred years later than the foundation of the great Corinthian dynasty. The reason for this slower development lies in the fact that the Athens meant morethan the city at the foot of the Acropol is; she was a territorial state. Before she found herself and could proceed along the path of political development there was the long preliminary task of establishing her political supremacy in Attica, the necessities of which led probably to a longer continuance of the monarchical system here than elsewhere.

For the tradition of the synoikism of Theseus suggests that the union of Attica must have been accomplished under the monarchy. The stages by which the subsequent devolution of the monarchy was carried out cannot be dated. The process is sketched in the Aristotelian Constitution of Athens but Aristotle himself was of necessity working from tradition or from inferences drawn from constitutional survivals rather than from documentary evidence contemporary with the events. Hetells us that the process of devolution was gradual. At first the royal office was limited in tenure and the hereditary king was replaced by a royal magistrate holding office for life. The military incapacity of individual kings then led to the appointment of a commander-in-chi ef (polemarch) to take over the military duties which had previously fallen to the king. The growing demands of public duties next necessitated the appointment of an extra judicial magistrate, the archon. All these three offices of basileus, pol emarch and archon were originally held for life. This tenure however was limited in the eighth century to ten years and finally in 680 B.C., when the growth of business necessitated the further appointment of six extra judicial magistrates (thesmothetae), all the offices became annual. The officials above enumerated became the board of nine archons, which constituted the executive of the early Athenian state, though according to Aristotle it was not until the time of Solon that their collegiate character was formally recognised by a common residence. ${ }^{4}$

In this board of magistrates the three elder creations retained a traditional importance and the evidence afforded by the duties assigned to them in historical times supports Aristotle's account of their evol ution. 


\section{W. R. Halliday, The Growth of the City State, 82}

The king archon (archon basileus) succeeded to the religious duties of the monarchy, and retained the control of the older religious ceremonies of the state. He presided also at the meetings of the Council of the Areopagus and, when performing this duty, wore a crown upon his head. The pol emarch, until after the battle of Marathon, remained the commanderin-chief of the citizen army. His sphere of authority included also civil jurisdiction over resident aliens, no doubt because originally the control of aliens living within the state was thought properly to fall within the domain of the responsible military authority. The third official, the archon, became the most important of the three. Primarily he was the judge in the civil court but he became during his year of office the representative of the state. As such he was responsible for the maintenance of the public hearth, the symbol of the state's welfare, and was lodged in the Town Hall (Prytaneum). He gave his name to the year, and official Athenian chronol ogy dates by the archonship of So and so. As the official head of the state hetended to encroach upon the duties of the king archon. Thus many of the national religious ceremonies which were of later origin than the fall of the monarchy, were under the control of the archon eponymus, as he is often called, and not under that of the archon basileus.

In Attica then as elsewhere the executive power of the king was divided up and vested in a number of aristocratic magistrates appointed eventually upon an annual tenure. This devel opment was due in part to the new needs of the community and in part to the pressure of an ambitious aristocracy. For the advisory council of the Homeric king survived the fall of the monarchy, and its powers and importance had naturally been increased in proportion as the magistracy had been weakened. When the archonship became annual the practice apparently obtained that the ex-magistrates at the end of their year of office passed automatically into the Council of the Areopagus, as it came to be called. ${ }^{5}$ In consequence this body, like the Roman senate, enjoyed the authority of an aristocratic assembly of ex-magistrates forming the permanent element in a constitution in which the magistrates held office only for one year, and thus exercised the real power in the state. ${ }^{6}$ 


\section{W. R. Halliday, The Growth of the City State, 83}

That aristocratic government suffered from the same defects in Athens as in other Greek states, and here, too, failed to adapt itself to the social and economic changes which were taking place, is shown by a premature and unsuccessful attempt at revolution. In the latter half of the seventh century an ambitious individual named Cylon endeavoured to make himself tyrant. ${ }^{7} \mathrm{He}$ was inspired by the example of successful tyrannies elsewhere; he was himself the son-in-law of the tyrant of Megara and relied upon the help of Megarian soldiers. It is significant, too, that he had the approval of Del phi, whose political influence at this time was in sympathy with tyranny.

Cylon succeeded in seizing the Acropolis but was unable to hold it. It would seem that the times in Attica were not yet ripe and that the attempt was the product of personal ambition relying upon foreign support rather than the necessary outcome of the internal conditions of the country. No popular rising supported the venture and national sentiment was probably antagoni sed by an attempt upon the constitution carried out by means of an alien force. ${ }^{8}$ The executive in consequence was able to crush the revol ution with little difficulty, though the massacre of Cylon's followers, who had taken sanctuary, brought religious pollution upon the state, the consequences of which were only averted by a ceremonial cleansing of the city carried out by Epimenides, the Cretan seer, and the expulsion of the whole family of Alcmaeonidae, both living and dead, to which the magistrate responsible had belonged. ${ }^{9}$

The massacre of Cylon's followers had further political consequences which were no less unfortunate for Athens than the religious. A long and disastrous war with Megara followed which aggravated the economic difficulties of the time, and the years between Cylon's coup d'etat and the archonship of Sol on must have been years of misery, distress and faction. In detail we have no reliable information about the events of this period. The outstanding event in its political history was the codification of the law which was carried through by Draco in 621.

Although its administration remained, no doubt, in the hands of the aristocracy, the establishment of a published code was a great and farreaching popular victory. Tolater ages the most noticeabl e feature of the 


\section{W. R. Halliday, The Growth of the City State, 84}

Draconian legislation was the severity of the penalties exacted, and the saying that "Draco's laws were written in blood" became proverbial. His code, however, showed in one respect a conspicuous advance in legal and ethical conceptions, the importance of which can hardly be over-estimated. F or the first time a distinction was drawn between voluntary and involuntary homicide, i.e between murder and manslaughter. Whereas murder continued to be tried before the old Council of the Areopagus, cases of manslaughter were referred to a new court consisting of fifty-one assessors (ephetai). It will be observed that the change involves a change of princi ple. Primitivereligi on had regarded homicideas in itself bringing pollution and theenmity of an angry ghost upon the community. Whether the killing was voluntary or involuntary, the consequences to the community werethesameand equal ly demanded expiation. I t was in fact the religious consequences of the act rather than the nature of the act itself which constituted the crime. Henceforth, however, homicide was regarded as constituting in itself, not merely in its ghostly consequences, a wrong against the community, and it therefore became possible and proper to draw a distinction between murder and manslaughter based upon the degree of moral responsibility of the agent.

The publication of the law was a great popular victory, it could not however by itself supply a remedy to the diseases of the state. ${ }^{10}$ These in Attica, as elsewhere, had their deep roots in the economic and social dislocation of society in an age of change. Economic distress was acute. The soil of Attica is stony and barren; population was increasing but Athens had not yet emerged as a first rate power in Greece nor had she found rel ief, as her enemy M egara had done, in colonisation. The peasant farmers were being eaten up by the landed nobility and small holdings were becoming merged in large estates. The economic difficulties of the peasant were aggravated by the introduction of currency into general use and by the hardships imposed by the pressure of the Megarian War. The transition from agriculture to commerce as the basis of national economics led inevitably to the emergence of a new class of wealthy merchants, who demanded the political recognition of their importance in the state. Political power, however, was concentrated in the hands of 


\section{W. R. Halliday, The Growth of the City State, 85}

the aristocratic council, and though the law had been codified its administration was still the monopoly of the wealthy nobility. In fact the conditions were precisel y those which resulted normal ly in the establishment of a tyranny. At Athens, however, an attempt was made to settle the difficulties of the state by constitutional means and to forestall the necessity for autocracy by a fair adjustment which did not involve the sacrifice of political liberty. That the attempt failed is a striking confirmation of the view that, when anarchy has reached a certain pitch, the strong hand of a single autocrat becomes a necessity and the restoration of order is impossible except at the price of a common servitude.

In 594 or 592 Sol on became archon. He belonged probably to the lesser nobility but he was a man abreast of his times, a merchant and a traveller. He was both courageous and far-sighted and inspired by a true and self-less patriotism. He is the first live figure in Athenian history and we are able partly to know the man from the fragments of his poems which have been preserved. In these he states his political faith and the motives which inspired him and they show us gifts of generous imagination tempered by shrewd wisdom such as few statesmen of any age or country have possessed.

Solon clearly saw that the evils of the day had their roots partly in economic and partly in political causes and that any attempt at reform must deal with both. His economic reforms, however, may be considered in a later lecture; our immediate concern is the constitutional changes, which he introduced. Much of theexisting constitution heleft untouched. The archonship remained the supreme executive of the state, ${ }^{11}$ the naucraries remained thebasis of financial administration, theA reopagus was unaltered except in so far that a new and more democratic council came into being. Nor did Solon attempt to alter the existing tribal organisation of society. The gene, phratries and tribes united by bonds of kinship and religion continued to form the political structure of thestate.

Following up and completing the work of Draco, Solon recodified and republished the law and, an important advance, he conferred upon any citizen the right of preferring a criminal charge. 


\section{W. R. Halliday, The Growth of the City State, 86}

Previously the right of bringing a charge had belonged only to the aggrieved individual or, in the case of homicide, to his next of kin. This change, it will be observed, implies a new point of view, viz., that a criminal action is not merely an offence committed against the individual who suffers from it, but is an offence against the whole of the body pol itic.

Solon further invented democratic machinery. He instituted a tribal Council (Boule) of four hundred members, one hundred from each of the four tribes. I ts duties wereto discuss and preparematters for the Ecclesia or popular Assembly, a mass meeting of the citizens in which he gave every citizen, however poor, the right of voting. The Boule had thus the power of initiating legislation, whilethe people, in a mass meeting, could control it by assenting to or dissenting from the proposals submitted to them.

Further he introduced a classification, which was new at least as applied to political purposes, ${ }^{12}$ dividing the citizens of Athens into four classes. The basis of this division was property qualification. The first class Pentacosio-medimni (five hundred bushel men) consisted of persons with an annual income of not less than five hundred measures of produce, the second Hippeis (knights) of persons whose income was between 300 and 500 measures, the third Zeugites (men with a yoke of oxen) of those whose income was between 200 and 300. All persons with incomes of less than 200 measures fell within the fourth class of Thetes (labourers).

This classification was made to determine both the amount of the burden of military obligation and the degree of political privilege of the citizen. The more expensive military service fell upon the rich. The first two classes provided the cavalry, the third the heavy armed infantry, the fourth, too poor to be called upon to provide themselves with equipment, served as light armed troops or as rowers.

Political privilege was similarly adjusted in proportion to the citizen's "stake in the country." The archonship was restricted to members of the first class and the holding of certain offices to those of the first two classes. Members of the first three classes were eligible to sit in the Boule, but not members of the fourth. Every citizen, however, including the Thetes possessed a vote in the Assembly. 


\section{W. R. Halliday, The Growth of the City State, 87}

This new arrangement is clearly very important and will have farreaching effects, for it introduces an entirely new principle into the constitution. It is quite probable that, at the time of its introduction, its full significance was hardly appreciated for no doubt the majority of the al ready ruling class were also the rich. But in reality it provides for the political representation of wealth. If the rich noble is archon, he is now eligible for that office not because he is noble but because he is rich, and any member of the new merchant class, whose income reaches the prescribed amount, will have a constitutional right, whatever his origin, to hold the highest office of the state. Previously to the Solonian classification political power had been the privilege of birth; Sol on made it the privilege of wealth and introduced the principle of determining the citizen's obligations and privileges in proportion to his "stake in the country."

Yet another, and, from the constitutional point of view, most important innovation of Solon remains. Solon created popular courts of appeal (Heliaea or Dicasteries) in which the judges consisted of large panels drawn from all classes of society. For Thetes as well as the first three classes had the right of sitting on these panels and the juries are therefore, as it were, committees of the Assembly. These courts constituted courts of appeal from the decisions of the archons in all civil cases, but their real importance is derived from the fact that every magistrate upon relinquishing his office at the end of his term was obliged to render account of his official actions before this court. "When the democracy is master of the voting pebble, it is master of the constitution" is the comment of Aristotle, and the power in fact conferred upon Athenian democracy by this control of the magistracy by the people was one of the foundations of popular liberty. ${ }^{13}$ Through the Ecclesia the people exercised a direct control over legislation; the popular courts gave them also the direct control of the executive.

Solon's reforms failed in their object of restoring internal peace and quelling party strife. The war of rival interests had become too acute for any section to be willing to accept the reasonable settlement of a compromise. A tyranny was in fact necessary in order to break the power 


\section{W. R. Halliday, The Growth of the City State, 88}

of the factions and to restore order in the state.

The little information, which we possess, of the fifty years between Solon and Peisistratus is plainly true in its general picture of the time. ${ }^{14}$ The struggle of rival interests was unabated and there Was fierce contention about the election of archons. A man called Damasias endeavoured to secure for himself a continuous magistracy. For twoyears and two months he remained in office, but was then driven out, a committee of ten being temporarily put in his place to discharge the functions of archon eponymus for the remainder of the year.

The rival sections in the state tended to crystallise into three great parties, the Plain, the Shore and the Mountain. ${ }^{15}$ Of these the Plain, whose leader was Lycurgus, consisted of the landowning class and represented the interests of the reactionary nobility. The Shore consisted of the new wealthy representatives of commerce and were led by the merchant prince Megacles the Alcmaeonid. Their policy was more moderatethan that of the reactionaries; political stability is inevitably an object tothecapital ist interest in any civilised community. The Mountain, so call ed from the poverty and lawless life of the shepherds, who pastured their flocks on the barren hill-side, was the extreme party of revolution, drawing its strength from all those who had nothing to lose and from "the impure by descent" who were discontented with their exclusion from political rights. ${ }^{16}$ Of this party Peisistratus, a young sol dier of distinction, became the leader and with their help he succeeded in seizing the throne and making himself tyrant. He was not able to do so without opposition. According to tradition he was twice expelled. On the first occasion a combination of the Plain and the Shore drove him out, but he succeeded in obtaining his return by making an alliance, cemented by marriage to his daughter, with Megacles the leader of theShore. Hefell out, however, with his father-in-law and was again expelled. With foreign assistance and financed by the mines in the Pangaeon district, in which he had acquired an interest, Peisistratus again returned and this time for good (circa 545 B.c.).

Peisistratus greatly developed the prosperity and international importance of Athens. In foreign policy he laid down the lines upon 


\section{W. R. Halliday, The Growth of the City State, 89}

which, after the Persian War, the Athenian empire developed and his cardinal aims were to establish Athenian influence at the Dardanelles and to make Athens the dominant state in the Cyclades and the recognised head of the maritime I onians. The friendship with Thessaly and Argos, upon which he based his foreign policy in Greece, also became traditional to Athenian diplomacy. At home, though he maintained a force of mercenaries, his power rested upon popular support. His economi creforms may be reserved to a later chapter. They were financed by the concentration of capital in the hands of a single ruler. The development of thesilver mines at Laurium provided him with money, as did also the sequestration of the property of his enemies. For, like all tyrants, he restored order by breaking the power of the noble or powerful families and the Alcmaeonidae, the quarrel with whom had caused his second exile, were banished.

Like a yet greater empire builder, Augustus, Peisistratus seems to have contented himself with the substance of power, while resigning its shadow. The Solonian constitution was allowed to stand in form and the tyrant contented himself with seeing that the higher offices of state were in fact held by his nominees. Popular tradition in Attica attested the mildness of his rule and its democratic character. He was succeeded by his son Hippias, a weaker character though apparently an amiable man with some taste in letters and art. In 514, however, a private quarrel resulted in an abortive revolution and the murder of one of the sons of Peisistratus by Harmodius and Aristogeiton. Hippias' nerve was shaken and the inevitable result was a reign of terror. Popular aspirations towards liberty and hatred for the tyrant's yoke naturally increased as that yoke became more heavy. External influences were also at work to secure the expulsion of the tyrants. The Alcmaeonidae had laid the god

at Delphi under an obligation by contracting for the rebuilding of his templeand carrying out their contract moremagnificently than theterms demanded. The considerable political influence of Delphi was consequently exerted to secure their return and in particular pressure was put upon Sparta, who in her own interests had adopted the role of the liberator of Greek states from tyranny, to restore the Alcmaeonidae. The 


\section{W. R. Halliday, The Growth of the City State, 90}

project harmonised with the ambitions of Cleomenes I who had made Sparta the ruling state in the Peloponnese and needed only to secure Athens to extend her domination over Central Greeceas well. In 510 with the help of a Spartan army the Peisistratids were driven out and the Alcmaeonidae restored. Cleisthenes, however, who was the head of the Alcmaeonid family, was not prepared to subject Athens to Sparta and to be the passive tool of the Spartan king. Sparta in consequence supported his rival I sagoras, revived the charge of the Cylonian curse upon the Alcmaeonidae and again invaded Attica in 508. But national sentiment was aroused. Their success was short-lived, the people rose against the foreign invaders and they were obliged to retire. Cleisthenes then became chief magistrate and it fell to him to devise constitutional machinery, which would perfect the work of Solon and enable democracy to function, while safeguarding the state against a recrudescence of tyranny or that warfare of parties to which tyranny had put an end.

Now Sol on had done something to solve the problem of the representation of wealth, but he had left untouched the old tribal organisation of society and had not attacked the problem of "the impure by descent." The political circumstances of the moment forced this question upon the attention of Cleisthenes. The party, which had set Peisistratus upon the throne, had been recruited from this discontented element in the state and after the expulsion of the tyrants the question of their status was a practical problem of immediate urgency.

Cleisthenes completely dissociated the old tribes, phratries and gene from politics and henceforward they had no political meaning. In the place of the four old tribes he created ten new ones into which the state was now divided for political purposes. The units of which these tribes were composed werelocal divisions of Attica not groups of kindred. Rural Attica had, no doubt, before been divided into demes or parishes, though Cleisthenes may have created them for the first time in the city. Membership of a deme was now made the necessary qualification of citizenship. Henceforward the demes also took the place of the naucraries as the units for financial administration.

The arrangement for distributing the demes among the tribes is at first 


\section{W. R. Halliday, The Growth of the City State, 91}

sight curiously elaborate. Attica was divided into three areas, the urban, the inland, and the littoral districts. Each tribe was divided into three parts, the trittys or third of a tribe consisting of a variable number of demes, but in every tribe one third was taken from each of the territorial areas and thus each tribe represented a number of demes from the city, the inland and the shore.

In the new scheme then the trittys and the deme took the place of the phratry and the genos, i.e. units whose cohesion was based upon the principle of locality took the place of units held together by the bonds of kinship. Deme cults were also introduced to take the place of the family cults and thenew tribes were bound together by the worship not of divine ancestors but of national heroes. It will be obvious that these substitutions robbed the hereditary aristocracy of much of its power. "M easures," says Aristotle in the Pol itics, "like those which Cleisthenes passed when he wanted to increase the power of the democracy at Athens or such as were taken by the founders of popular government at Cyrene, are useful in the extreme form of democracy. F resh tribes and brotherhoods should be established; the private rites of families should be restricted and converted into public ones; in short every contrivance should be adopted which will mingle the citizens with one another and get rid of the old connections." ${ }^{\prime 18}$

Theobject of the geographical arrangement was probably to prevent any single local interest controlling the tribe. It was conceivable, for instance, that had the tribe consisted of contiguous demes a particular family or interest might predominate throughout its area, but it was extremely improbable that any single family would be in a position to dominate a tribe bel onging partly to the city and partly to two other separate areas in Attica.

Two results of this grouping of the demes may be noticed. On the one hand the arrangement cemented the union of Attica and prevented the development of divergent interests between the city and therural demes. On the other hand owing to the fact that each tribe contained an urban trittys, the country voter, who was hampered by distance, tended to be outvoted by the town voter, who lived on the spot. 


\section{W. R. Halliday, The Growth of the City State, 92}

The new system al so solved the difficulty of "the impure by descent." So long as the body politic consisted of a number of related families there was no possibility of "the impure by descent" qualifying for full political privileges, but when the principle of locality was substituted for the principle of kinship as the determining qualification for citizenship, it became possibleto incorporatethese persons. This very important aspect of Cleisthenes' reorganisation was clear to Aristotle. "Cleisthenes," he remarked, "attracted the people to his si de by giving the franchise to the masses; he enrolled in the tribes a number of strangers and slaves and resident aliens." ${ }^{\prime 19}$ It is true, however, that this aspect of the political reorganisation of the Athenian state had only a temporary force, for though the deme was in itself a local unit, membership of the deme was hereditary. If for example a man $X$ bel onged to the deme of Collytus and went and settled in the deme of Paeania, he remained " $X$ of the deme of Collytus" and paid a small fee for living in the deme of Paeania. His son, even if he were born in Paeania would be entered on the register of his father's demeand would beknown as " $Y$ son of $X$ of the deme of Collytus."

It is an unfortunate feature of all political classes and by no means a peculiar sin of aristocracies, to grow more selfish as they become more powerful. Both in Greece and Rome as the powers and perquisites of citizenship increased the popular party becamemorejeal ous of extending the franchiseand ai med rather at restricting it. In Athens the reactionary but extremely popular law of Pericles in 451 B.C. ultimately restricted the citizenship to persons who were of Athenian parentage upon both sides, a law which would have disfranchised, had it been earlier operative, Themistocles, Miltiades and Thucydides amongst others.

There remain to be considered the democratic machinery, which Cleisthenes invented, and the peculiar and not very successful political device of ostracism which he first introduced. F or the Sol onian Council of 400 he substituted a Boule of 500 consisting of fifty members from each of the new ten tribes. This Council drafted all legislation, dealt with foreign affairs and controlled the whole administration of the state. An experience however slight of the organisation of a club or society will be sufficient to illustrate the necessity of having some smaller and more 


\section{W. R. Halliday, The Growth of the City State, 93}

experienced body than the general meeting of the members to frame and direct its policy. Such experience will also suggest that on the one hand a committee of five hundred is too large for the efficient discussion and preparation of business, while on the other hand it will be difficult in view of the enormous amount of business, which such a body will plainly have to get through, to enforce the continuous attendance of the whole body of members. Under such conditions it would probably happen that a small caucus of keen and professional politicians would alone attend regularly and would thus get control of the state, acting in the name of the larger body whose members stayed away from exactingly frequent meetings, or policy would come to be directed by officials and a bureaucracy would obtain control. To guard against this an ingenious system was adopted. Theyear was divided into ten parts corresponding to theten tribal contingents of fifty. Each tribal group took it in turn to act as a standing committee (prytany) of the Boule for a tenth part of the year. The prytany received and discussed the business and prepared it for and introduced it into the Boule and the Ecclesia. In this way provision was made for the continuous transaction of business and its adequate preparation before reaching the larger bodies. Their control over agenda naturally gave the prytanies enormous power of forwarding or obstructing business, a power which was often abused. ${ }^{20}$

The Boule had the initiative in all legislation but the Ecclesia retained the last word and in it the people could directly ratify or reject the recommendations laid before it. But the Athenian Ecclesia was widely leavened with firsthand pol itical experience to a degreeto which no other popular assembly can lay claim. Membership of the Boule was limited to a year, and no citizen might be a member more than twice. The result in a state of the small scale of ancient Athens was that at any given moment about a quarter of the citizens, who voted in the Assembly, had had, as members of the Boule, practical first-hand experience of the conduct of public business.

As regards the magistracy the archons continued to be the elected principal officials of the state until 487 when selection by lot was substituted for election. The inevitable result was a decline in the power 


\section{W. R. Halliday, The Growth of the City State, 94}

of the archonship and from that time the list of archons becomes a series of names of political nonentities. This decline contributed to the rise of the office of general, which remained elective, to the chief political importance, a devel opment which was naturally assisted by the fact that the problems of $\mathrm{F}$ ifth Century Athens weremainly imperial and military.

After 487 the generals constituted a tribal board of ten members and the practice of appointing officials in boards of ten, one from each of the ten tribes was the logical outcome of Cleisthenes' reorganisation, though only one such board can certainly be traced back to his creation. ${ }^{21}$

The political device of ostracism, which acquired its Athenian name from the pieces of pottery upon which the votes were recorded, ${ }^{22}$ was not peculiar to Athens but it seems to have been copied elsewhere from the invention of Cleisthenes. In the sixth prytany a vote was taken whether or not a process of ostracism should be held that year. If the vote was adverse no further action could be taken in that year, and if ostracism were resorted to a minimum of six thousand votes had to be recorded for the opinion of the majority to take effect. But within these restrictions, ostracism enabled the people, if they so decided, to banish for ten years one of the prominent statesmen of the day. The object of this curious device was no doubt to limit the warfare of parties by the removal of one of the rival political leaders. It was freely used up to the Persian war and in fact at the time of theinvasion of Xerxes practically all the outstanding political figures with the exception of Themistocles were in exile. In the party struggles after thePersian Wars it was again employed. Cimon was ostracised in 461 and Thucydides son of Melesias the last of the serious rivals of Pericles in 443. Then the long ascendancy of Pericles seems to have led to its disuse. It was once again revived in 417 when an attempt to remove one of the rivals $\mathrm{Nicias}$ or Alcibiades ended farcically in the ostracism of Hyperbolus. ${ }^{23}$

As a political device ostracism had very obvious defects. It might involve the loss by the state of the services of her best men at a critical period when they were most wanted. Thus both Aristei des and Xanthippus, the Athenian commander at Plataea, were in exile when Xerxes invaded Greece and were only recalled by special decree. Again it was unjust to 


\section{W. R. Halliday, The Growth of the City State, 95}

the individual ostracised to send him into banishment for ten years upon no definite charge, still less upon the conviction of any crime. But still worse was the fact that it suppressed the rights of minorities. The opposition in a democracy serves a useful function and it has the right to have its views represented. Ostracism arbitrarily crippled the party which was in the minority by banishing its leader. The result of arbitrary suppression is to drive political feeling, deprived of constitutional means of expression, underground and natural resentment will find unconstitutional means of venting itself. Thus the murder of E phialtes the popular leader and the conspiracy of the conservatives before the battle of Tanagra may be directly attributed to the ostracism of the conservative leader Cimon in 461 B.C.

\section{Notes to Lecture V.}

1. Plutarch has preserved an interesting piece of evidence for the existence of these independent political communities in early Attica by recording that even in historical times the inhabitants of certain demes possessed no rights of intermarriage with those of other demes (Plutarch, Theseus, 13). Traces of the village groups survived in the religious associations of historical times like the tetrapolis of Marathon or the four villages at the Piraeus which were associated in a common worship of Heracles. The matter is discussed by Wilamowitz, Aristotel es und Athen II, p. 35, who thinks that many prominent local cults like that of Nemesis at Rhamnus or of Artemis at Brauron were originally the cults of independent political units.

2. Thucydides II, 15.

3. There are several interesting points about the conquest of Eleusis which was evidently effected only after a long and difficult struggle. It must have happened after the Homeric Hymn to Demeter had taken its present shape and after Eleusis had passed from the monarchical stage to the aristocratic. The terms are complicated and must have demanded a written contract, though the payment of the tithe points to a date anterior to the use of money. Under the provisions of the 


\section{W. R. Halliday, The Growth of the City State, 96}

settlement the Eumol pidae, the aristocratic rulers of Eleusis, retain their priesthood of the goddesses. The control of the Mysteries is vested in a joint board consisting of the Athenian king with two Athenians on theonehand and tworepresentatives of theE umol pidae on the other. There is no evidence of distraint upon the treasure of the goddesses, the national treasury of the Eleusinians, while the Athenians on the other hand pay tithe of the grain crops of Attica. (See further Wilamowitz, op. cit., II, p. 38.)

4. Aristotle, Ath. Pol. 3.

5. Probably before the time of Solon this, then the only council in the state, was called Boule (Council). But when Sol on set up a new council it was necessary to distinguish the older from the new creation and in consequence its place of meeting gave the former the title of Council of the Areopagus. This is the most probable explanation of the mistaken idea, which was prevalent in later classical times, that Sol on originated the council of the Areopagus.

6. "This was the natural consequence of the facts that the archons were elected under qualifications of birth and wealth and that the Areopagus was composed of those who had served as Archons: for which latter reason themembership of theAreopagus is the only office which has continued to be a life magistracy to the present day" (Aristotle, Ath. Pol., 3). Aristotle's view is patently based upon a rather slender argument from constitutional survival but the Roman analogy supports its probability.

7. Herodotus V, 71, Thucydides I, 126. Cyl on won his Olympic victory in 640. The date of his attempted revolution is probably about 632.

8. Foreign interference with their constitution was a matter upon which Athenian national sentiment was sensitive as Cleomenes I of Sparta discovered to his cost (Herodotus V, 72).

9. Megacles the Alcmaeonid was archon and therefore the executive head of the state and responsible for this sacrilegious murder. Herodotus' attempt to shift the blame on to the presidents of the naucraries is no doubt due to the strong bias which he shows throughout in favour of the family to which his friend and patron Pericles belonged. But 


\section{W. R. Halliday, The Growth of the City State, 97}

further the attempt to lay the blame upon other shoulders had a particular point at the time when he was writing his history, for the demand that theAthenians should reinforcethesentence of expulsion against the accursed Alcmaeonidae (i.e, expel Pericles) was one of the political manifestoes issued on the Pel oponnesian sideat the outbreak of the Peloponnesian War (Thucydides I, 126).

10. Aristotle's Constitution of Athens ascribes to Draco an attempt to remodel the constitution. It is pretty generally agreed however that "the constitution of Draco" is an invention drawn from the political literature of the end of the fifth century B.C., when political pamphleteering tended to adopt an historical form in order to obtain an historical sanction for its proposals. No other ancient author gives even a hint that Draco anticipated Solon in an attempt at constitutional reform. The constitution attributed to him in the Constitution of Athens is inconsistent with Aristotle's statements in the Politics and even in some respects with statements in the Constitution of Athens itself. Its general character is suspiciously similar to the political programme advocated at the end of the fifth century by the "moderates," who posed as champions of the "constitution of our fathers," and in detail there appear to be anachronisms. For instance both the property qualification and the fines laid down in the "constitution" are stated in terms of currency, whereas the laws of Draco are innocent of money economy and the fines are assessed in cattle. Even in Scion's classification of society property qualification is expressed not in drachmae but in measures of agricultural produce.

11. The Constitution of Athens, cap. 8, states that Solon altered the method of the appointment of archons from election to "mixed sortition," i.e. the selection by lot from a number of selected candidates. This statement has been accepted by some historians including Bury (History of Greece, pp. 185-186). There are however some reasons for questioning the accuracy of this remark which is clearly based upon an inference from the way in which certain appointments were made in the fourth century. If Solon adopted this new method when and why was it abandoned? Further, such information as we 


\section{W. R. Halliday, The Growth of the City State, 98}

possess points to the continuous practice of election until 487. In the period between Sol on and Peisistratus el ection appears to be the rule, eg. Constitution of Athens, 13. "Damasias was elected archon." It is not very probable that Peisistratus would prefer election by lot when it was his policy to fill the archonship with his nominees. After the date of Hippias' expulsion the archons were elected not appointed by lot until 487. "Then in the very next year, in the archonship of Telesinus (i.e, 487), they for the first time since the tyranny elected tribe by tribe, the nine archons by lot out of 500 candidates selected by the demes, all the earlier ones having been elected by vote " (Constitution of Athens, 22). In the Politics, a work far moreauthoritative for Aristotle's considered view, the Solonian magistrates are explicitly stated more than once to have been elected. "The truth seems to be that the council (of the Areopagus) and the elected magistracy existed before the time of Sol on and were retained by him" (Politics II, 12, 3, 1274a, cf. II, 12, 5, 1274a, and III 11, 8, 1281b).

12. It is probable that the names Hippeis, Zeugites and Thetes al ready existed as popular social labels, although no doubt they had previously no connection with pol itical qualifications. I t will benoticed that they differ in character from the name of the first class, which expresses directly the qualification sttached to it.

13. Constitution of Athens, 9; cf. Politics II , 12, 3, 1274a, "he formed the courts of law out of all the citizens thus creating the democracy, which is the very reason why he is sometimes blamed. For in giving the supreme power to the law courts, which are elected by lot, he is thought to have destroyed the non-democratic element." It has frequently been pointed out that this popular control of the executive is as fundamental to Athenian constitutional history as the control by the House of Commons of finance is to that of Great Britain.

14. Our main source of information is the 13th chapter of the Constitution of Athens which has clearly been taken bodily from a local history of Attica by one of the fourth century antiquaries. In detail there are some obvious difficulties and the chronology has evidently got into a muddle but there is no reason to doubt the general accuracy of the 


\section{W. R. Halliday, The Growth of the City State, 99}

picture presented of these years.

15. It is perhaps improbable that the names of these parties are more than nicknames or have any strict territorial significance beyond a vague and obvious appropriateness. The differences which were tearing Attica asunder were not local in character but social and economic. Professor Ure in The Origin of Tyranny has recently tried to show that the party of the Mountain consisted of the miners of the Laurium district. I am unable personally to accept his conclusions. Finally there is no evidence that the names of these political parties have any connection with the territorial division of Attica under Cleisthenes' scheme of reorganisation (see p. 127) and it seems to me highly improbable that they had.

16. A summary of the reign and policy of Cleomenes I and a discussion of the chronological problems, which are raised, will be found in How and Wells, Commentary on Herodotus.

17. "To this latter party (the Mountain) were attached those who had been deprived of the debts dueto them from the motive of poverty and those who were not of pure descent, from motives of personal apprehension. A proof of this is seen in the fact that after the tyranny was overthrown a revision was made of the citizen roll, on the ground that many persons were partaking in the franchise without having a right to it." (Constitution of Athens, 13).

18. Aristotle, Politics VI, 4, 18, 1319b.

19. Aristotle, Constitution of Athens, 20, Politics III , 2, 3, 1275b.

20. See [Xenophon] Constitution of Athens III I I III , 3. The corruption of the prytanies is a frequent topic of jest with Aristophanes, eg.,

"Grant me one request, O by that hand I pray you, which you love To hold out empty and to draw back full."

(Thesmophoriazusae, 936; cf. Peace 905). A clause is frequently inserted in decrees to ensure that matters shall be brought forward by a certain date and shall not be indefinitely held up by the prytany. Examples will be found in Hicks and Hill, Greek Historical Inscriptions, Nos. 40, 41, 64.

21. The number of boards of officials naturally tended to increase with 
the increase of business. Nearly all were boards of ten. The first tribal election of generals is dated by Aristotle to 502 B.C. (Constitution of Athens, 22). At that time the generals were the leaders of the tribal levies and subordinate to the Polemarch, who was still the commander-in-chi ef at the battle of Marathon. Theintroduction of the election of archons by lot in 487 led to the abolition of the military duties of the Polemarch, for citizen soldiers were not willing to trust their lives to a general selected by lot. (On this see [Xenophon], Constitution of Athens, I, 3). For any particular expedition an odd number of the generals of the year, usually three or five, was appointed by a special vote of the Assembly to command. One of these was regarded as the president. This is the meaning of the constantly recurring phrase "himself the third" or "fifth," placed after the last name of the list of generals sent upon any expedition, the person so designated being in fact the president. The generals were originally tribal officers elected by and out of the ten tribes. In 467 they still appear to have been so elected, but in 440 Pericles and Diomedon were generals together though they bel onged to the same tribe, and in 408 Alcibiades and Adeimantus, who werefellow demes-men. Probably at this time the generals were still elected for and by but not necessarily from each tribe. See Daremberg et Sagl io, Dictionnai redes Antiquith, IV, p. 1523, s.v. Strategos.

22. Three of the fragments of pottery used in ostracism are displayed in the British Museum inscribed with the names of Megacles, son of Hippocrates, ostracised 487, Xanthippus, the father of Pericles, ostracised 486, and the great Themistocles who was ostracised about 471. A reproduction of these will be found in the British Museum Guideto theExhibition illustrating Greek and Roman Life, p. 7, fig. 4. 
Lecture VI. The Early Constitutional Development of Rome.

The early history of Rome is shrouded in even darker uncertainty than the early history of Athens. Our literary authorities are writing centuries later than the event; none of them inspires confidence by his method of handling evidence; their material itself is poor in historical quality. It is probable that in the sack of Rome by the Gauls in 390 B.C. all existing records were destroyed and the history of the period before that event lacks therefore any sound chronological or documentary basis and is dependent wholly upon tradition. It must further be remembered that many of the later Roman historians were Greeks, while the early annalists though Romans wrote in Greek, and if Roman mythology was transformed by Greek legend, the secular tradition has suffered from a similar process. A Roman historian, for example, thinks nothing of narrating as an episode in the career of Tarquin the Proud, a story told by the Greeks of Thrasybulus of Miletus. ${ }^{1}$

It is probable that Rome grew out of the amalgamation of settlements upon the hills, which command the crossing of the Tiber. The first settlement on the Palatine coalesced with those upon the Esquiline to form the community of the Seven Hills and this later amalgamated with the Sabine occupiers of the Quirinal. The whole was extended, fortified and drained under the late monarchy. The commercial as well as the strategical importance of the site has been previously remarked and, in fact, Rome like Mycenae or Troy was "a fortified centre of exchange" planted on a trade route and, no doubt, enriched by the exaction of tolls from the commerce which she controlled.

That the site formed the junction of the trade route from the river mouth inland with that running north and south across the river is, no doubt, in part responsible for the growth of population and the rapid increase in the number of the unprivileged classes, which evidently took place under the monarchy.

For early Roman society like Greek was based upon the family and 
political privilege was restricted to those within the kin. The unit was the family in which the father, paterfamilias, had supreme authority. The members of the family and the estate of the family, including the possessions of its individual members, were "in his hand."Thefather was sole trustee for the family property, individual members enjoyed the possession of private property (peculium) not as a right but only as a grace. The father was naturally the only member of the family who could exercise legal rights. Over the members of the family he possessed the powers of life and death ${ }^{2}$ and his responsibility for the welfare of the family and the administration of family property was accompanied by complete powers inside it. This power was limited only by custom, which ordained that in matters of importance it was proper for the father to consult a family council before coming to his decision.

A group of related families made up the gens or clan and their common descent was indicated by their common name. Had I sagoras been a Roman, Herodotus need not have appealed to his religious cult to establish his geneal ogy, for his name would have declared it. Thus Gaius Iulius Caesar indicates an individual named Gaius belonging to the family of Caesar, which is one of the group of families belonging to the Iulian clan.

As in the early Greek states, membership of the clan was an essential qualification for citizenship, and citizenship included not merely political privilege but all civil rights of any kind. The need for personal protection, which this implies, led to the creation in Rome, as in Greece, of a class of dependents upon the clan, who obtained the protection of the clan by the fiction of adoption but were not full members and did not share their political privileges. These dependents were called clientes or "listeners" and the head of the family upon whom they were dependent was their "protector" (patronus). Clearly, as the state devel opes, the problem of the political representation of the "impure by descent" will necessarily arise and the unprivileged masses (Plebeians) will demand concessions from the men of family (Patricians), who enjoy themonopoly of political rights. ${ }^{3}$ The earliest constitution of Rome of which we have knowledge is a monarchy, though monarchy had al ready become limited and had fallen 


\section{W. R. Halliday, The Growth of the City State, 103}

from the high estate of hereditary tenure, which it no doubt originally possessed, to the life tenure of an elected king. The powers of the life magistrate in the community were conceived as analogous to those of the pater familias in the family. He possessed imperium, i.e., complete executive authority and powers of life and death. Like the Homeric king, he was the supreme commander in war and was responsible for the maintenance of right relations between the community and thegods. Like Agamemnon, too, his secular power was restricted by custom though not by law. Beside him stood the aristocratic council of the F athers (Patres), and their advice he was expected to take in all important matters. In the earliest times of which we have record this aristocratic council had great powers. The monarchy had al ready become el ective and upon the death of the king it was the senate, the aristocratic council, which made arrangements for the interregnum until the new king was appointed, and from its members was selected the interrex, whose duty it was to carry on thework of government during theinterval. On the other hand the senate could only meet when summoned by themagistrate and its personnel was determined by royal nomination, though the monarch's choice was of course restricted to members of the aristocracy.

Thethird estate, the Populus or people, had little real power. They could vote their assent or dissent to a definite question (rogatio) laid before them by the magistrate but possessed no powers of free debate. For purposes of voting, the people were organised into larger groups of kindred than gentes called curiae, corresponding in structure though different in function to the Athenian pbratries. These curiaeor groups of clans met in an assembly called the Comitia Curiata in which each curia had one vote, and a decision was effected, not by a majority of individual votes, but by a majority of group votes. This is of some importance, for group voting remained a characteristic of all Roman popular assemblies throughout Roman history. Only in the senate was there voting by individuals, all other pol itical assemblies voted by groups and each group, whether numerically larger or smaller than the others, had one vote.

In early Rome, then, there was a life magistrate enjoying complete executive authority but by custom compelled to take the advice of a 
council whose members, though appointed by himself, could only be selected from thearistocracy. Thecitizen body had no deliber ative powers and voted not by individuals but by groups of kinship, a system which naturally increased the power of the heads of kin in affecting its decisions. Outside the citizen body there existed a growing class of the unprivileged, thePlebs, some of whom acquired the civil protection of the clans by becoming clients, a status which did not however confer political rights.

Of the traditional kings of Rome the last three, L. Tarquinius Priscus (616-579), Servius Tullius (578-535) and L. Tarquinius Superbus (534-510) were in all probability Etruscan usurpers. Under their rule, however, Rome grew in size and strength. She succeeded Alba Longa as the chief city of the Latins and under Servius Tullius thetemple of Diana, the new religious centre of the Latin League, was said to have been founded on the Aventine. To the same king tradition ascribed the "Servian wall", which united within one line of fortifications the whole of what became the Rome of republican times. U pon architectural grounds it is impossible to admit so early a date for the fortifications which the Romans called "Servian", and they cannot in fact be earlier than the period following the sack of Rome by the Gauls, but tradition may well be correct that the Etruscan rulers enlarged the area of the town and encl osed it in a ring of fortification.

ToServius is also attributed the introduction of a military organisation which was to have far-reaching consequences. In Attica a contemporary Athenian statesman was introducing the principle of wealth as the qualification for determining both political privilege and military obligation. The motive of the very similar Servian reform was primarily military but the imposition of obligations creates just claims to representation and important political results followed. The state army was reorganised by Servius upon the basis of five financial classes, each of which was subdivided according to age into iuniores (from eighteen to forty-five) and seniores (forty-five to sixty). ${ }^{4}$ The burden of the most expensive service, the cavalry and the fully-armed heavy infantry, fell upon the richest class and throughout the degree of military obligation 
was graded in accordance with the economic status of the individual. In war the state could not afford to lack the services of the unprivileged classes, and Plebeians no less than Patricians served in the categories decided by their degree of wealth.

From this military organisation developed a new popular assembly, a meeting of the armed forces of the state on their drill ground of the Campus Martius, which voted not in groups of kinship but in centuries, i.e, in groups of the military organisation. The importance of this is obvious. When the people met in arms in an assembly organised without reference to qualifications of kinship but solely on the basis of wealth, the "impure by descent" acquired a new status in the body politic. They had not, it is true, achieved citizenship but they had obtained a point of vantage from which to begin the struggle for complete political recognition.

Solon had applied the principle of property qualification to political office, the Servian reform does not go so far, although in fact it gave the dominating influence to wealth within the Comitia Centuriata, as this new assembly was called. The centuries, the military groups which formed the units of the assembly, were not numerically uniform and the centuries of the rich comprised a smaller number of individuals than the centuries of the poor, but the larger size of the groups into which the lower classes were divided was of no influence in voting, because each century, whether large or small, had one vote. Out of 194 centuries 100 belonged to the first or richest class (18 centuries of cavalry, 2 of engineers and 80 of infantry) so that wealth commanded a majority of the votes. It had further the advantage, a considerable one in a Roman assembly where the tendency was al ways to vote in accordance with the lead given by early voting, in that the votes were recorded in the order of the grades and the centuries of the rich voted first.

The division of the people into classes for the purpose of determining their degree of military obligation was based as at Athens upon the amount of landed property which they possessed, though the Servian assessment was made upon capital valueand not, liketheSolonian, upon income. The assessment served also to apportion the burden of supplying 


\section{W. R. Halliday, The Growth of the City State, 106}

the sinews of war, and the war tax (tributum) consisted of a percentage upon the registered property of the citizen. For the purposes of assessment and collection citizens and their property were registered in four local divisions called tribes; the number of tribes was afterwards increased as the landed property of Roman citizens was increased by conquest. In 471 there were twenty-one, and eventually the number reached thirty-five, of which thirty-one were "rustic" tribes, and four,

which bore the names given to them by Servius, purely urban. ${ }^{5}$ This system of classification obviously makes a periodic registration of the citizens necessary. Under the Republic this was carried out every five years, in the first instance by the consuls, and after 443 by the censors. The numbering of the people was followed by a solemn purification from which derived the name lustrum for one of these quinquennial periods.

The Roman monarchy fell as the result of a national and aristocratic revolution. It would appear that Tarquin the Proud endeavoured to dispense with or to override the advice of the aristocratic council. Acts of violence and the exaction of forced labour for public works had alienated the people and the senate, threatened with an infringement of its customary constitutional rights, found support in the national dislike of an alien rule and the personal unpopularity of the tyrannical Tarquin.

The revolution resulted in the expulsion of the king and the abolition of the monarchy; the very title rex was henceforward an offence to Roman ears and it survived only in that of a politically unimportant religious functionary, therexsacrorum. But though thekingly officewas abolished, the conception of imperium, the complete executive authority of the magistrate was retained unimpaired. I ts exercise, however, was limited by thenew constitutional arrangements. Executiveauthority was put into commission and conferred upon two annual officers. These consuls, as they were called, possessed imperium but their power as compared with that of the king was limited. In the first place they held office not for life but only for one year. In the second the power of each consul was limited by the existence of a colleague enjoying equal powers. In the case of a conflict of authority between thetwo magistrates, thenegativeruling was held to be the stronger and the exercise of imperium by a consul might 
always be restricted by the veto of his coll league. The king had possessed full powers of life and death and, if there was the possibility of a popular appeal from capital sentences under the monarchy, it rested upon custom not upon law. But soon after the establishment of the republic the Lex Valeria provided that full citizens should have the right of appeal (provocatio) to the people from the decision of the magistrate in all cases involving capital punishment or loss of civic rights. Only in the field, as commander-in-chief of the forces of the state, did the republican magistrate retain the power of life and death.

This limitation of the complete imperium of the magistrate within the city was symbolically represented in the insignia of his office. The king had been accompanied by attendants (lictores) carrying bundles of rods with an axe tied in the centre (fasces) which symbolised his power to inflict summary punishment whether by beating or by death. Henceforward theaxes, though retained in thefield wherethe commander-in-chief had still the power of inflicting the death penalty, were omitted from the consular fasces in the city.

Another of the insignia of imperium may be mentioned. The king had possessed the sole right of driving in a chariot through the city. Possibly from this derived the sella curulis (curule chair), a kind of folding seat which was carried by the attendants of a possessor of imperium. In the presence of such a magistrate it was proper that the citizen should stand while the magistrate should be seated. This chair is the origin of the phrase "curule magistracy" which in after times was applied to the major magistracies of the Republic, which conferred imperium on the holder. In the early Republic the consuls were the sole magistrates and therefore the sole possessors of this wide and undefined executive power.

One of the limitations, however, of the consul's power as compared with that of the king consisted, as we have seen, in the existence of a coll eague with positive powers of equal scope and with the negative power of veto. This division of authority might obviously prove disastrous in a national emergency. Now the expulsi on of the Tarquins had involved Romein war with the powerful Etruscan friends of the tyrants and, throughout its early history, the state was fighting hard for its existence. A military 
crisis might ther efore well arise in which the conditions of divided control were a menace to the welfare of the state, a crisis which demanded that decisive action which could only be obtained through unity of command. Provision was made for such emergencies. After consultation with the senate the consul might nominate a single dictator with supreme authority. In effect the state was thus put under martial law and a state of siege proclaimed : the appointment of a dictator consequently suspended the law of appeal. ${ }^{6}$ But the investiture of an individual with imperium unlimited by the existence of a colleague or by the right of appeal was safeguarded by the temporary character of its tenure. The dictator was appointed ad hoc, to steer the state through a particular crisis; when the crisis was past, he must lay down his powers. The maximum length of tenure was fixed at six months, a period no doubt representing the normal duration of the campaigning season. For though it was sometimes employed for pol itical purposes the office was originally designed to meet military emergencies. The Roman Republic was the outcome of an aristocratic revolution; it was not democratic in character and it never developed into a democracy. I ts most noticeable feature indeed is the wide powers which it conferred upon its two executive magistrates. The consuls, like the I cing, nominated the members of the senate and neither senate nor assembly could meet unl ess summoned to do so by the magistrate. But custom is everywhere a potent force in moulding constitutional rights and nowhere more so than in Rome. The inevitable advantages possessed by a permanent and experienced aristocratic council over magistrates drawn from its own order and holding office upon an annual tenure, we have already noticed. In the nomination of members the consul's choice was restricted by custom. According to constitutional theory the senate even in the time of the monarchy, had been the body in which the permanent existence of the state was ultimately vested, for if the magistracy ceased to exist, the auspicia, i.e, the divine sanction upon which the magistracy rested, "returned to the Fathers," the Patrician senate, which was therefore responsible for making provision for government until the auspices had been elicited anew for another magistrate. In practice under the Republic 
the senate acquired an increasing control of the direction of policy and became the true ruler of the state. Although in theory it remained an advisory council, custom made it obligatory for the magistrate both to asks its advice upon all matters and, when that advice was given, to follow its direction. The senate's advice to the magistrate came in fact to have the force of a command. The growth of the power of the senate was assisted by the hold which, from the first, it had obtained over foreign policy, for in foreign policy from the foundation of the Republic to the close of the Great Wars lay the main interests and problems of Rome. It was rendered inevitable no less by internal constitutional development, which resulted in the multiplication of magistracies and assemblies and consequently in the division and weakness of the other elements in the constitution.

The establishment of the new constitution brought the privileged and unprivileged classes in the state into di rect opposition. We have al ready noticed the existence of Plebeians, a class consisting of persons who were unable owing to theimpurity of their descent to attain to full citizenship. Under the monarchy, the policy of which had been to play off popular support against the nobles, the Plebeians had enjoyed a measure of protection. They had also no doubt increased considerably in numbers. The Etruscan rulers had enlarged Rome and made her a political and commercial power. Foreigners in increasing numbers settled in the new city. It was the foreign artizans for example who brought with them from Etruria the worship of Minerva, the patroness of handicraft.

In the old Comitia Curiata they had no voice, ${ }^{7}$ but the Servian reform had given them a place in the body politic. The state had claimed their services in war and their financial contributions to military expenditure, in return it had thereby recognised the right of Plebeians to hold landed property $^{8}$ and it had given them votes in the assembly of the people under arms. This assembly was becoming more important than the Comitia Curiata. It now elected the consuls and received appeals under the Valerian law. But although the Plebeians were members of the Comitia Centuriata they could exert no appreciable influence upon its decisions. Though there may al ready have been a few wealthy Plebeians, the rich 
were in the main Patricians, and in voting strength the centuries of the rich had an overwhelming preponderance. Further the Comitia Centuriata was not an assembly which enjoyed powers of free debate; ${ }^{9}$ it was dependent upon being convened by the magistrate and could but give an answer to "the question" which he put before it. But the magistrate, upon whom it was thus absolutely dependent, could not be a Plebeian, for the Patricians had the monopoly of the magistracies as well as of the law, both religious and secular.

The rank and file of the unprivileged class had naturally but little political ambition. They had no desire to obtain a technical eligibility to the high offices of state, but they felt acutely their social and economic disabilities, which could not be removed except by their obtaining and exercising political power. Their military and financial obligations to the state hel ped to involve the poorer classes in debt and the severity of the law which in Rome, as in Athens, permitted the creditor to seize the debtor's person, created severe economic distress. It was further felt to be an injustice that although the Plebeian fought in the army of the state, the Patricians claimed the monopoly of the public land attained by conquest.

If the constant warfare in which the early Republic was engaged aggravated the economic distress of the Plebeians, it also gave them an invincible weapon. Their military service was indispensable to the continued existence of a state which was fighting for its life. In consequencePlebeian discontent could not beignored when it found expression in the refusal of military service. The first great crisis in the Struggle of the Orders occurred in 494. The Plebeians, not individually but collectively, refused service. They marched to the Mons Sacer, as the hill was afterwards called, and threatened to form an independent community unless their grievances were met. To this threat the Patricians were bound to yield. Their spokesman, it is said, recited the F able of the Belly and the Members and both sides knew well enough that, unless a compromise could be reached, the Roman state was doomed.

The Plebeians returned upon terms. The Plebeian body was recognised as a corporation within the state; to employ the language of modern 


\section{W. R. Halliday, The Growth of the City State, 111}

industrial warfare, the strike was settled by the recognition of the union. This corporation was to have power to meet in a council (Concilium Plebis) competent to pass regulations (plebiscita), which were binding upon its own members but not upon the state as a whole.

Further the corporation was to have officers of its own; they were given the title of tribunes and were in the first instance two, though the number was subsequently raised to five and then to ten. They had power to convene the Concilium Plebis when they wished and lay before it any matter which they chose. N o magistrate of the state or other person could prevent their doing so nor interrupt their speeches. I $\mathrm{n}$ itself this afforded an opportunity which had previously been lacking, for giving public expression to Plebeian feeling. More it did not give, for resolutions which were carried at the meetings of the Concilium Plebis were not laws nor binding except upon members of the Plebeian Order.

The tribune was an officer of the Plebeian body not an officer of the state; he had no imperium. But in relation to the state very important negative powers were conferred upon him in order to enable him to perform his function of protecting Plebeians from injustice. These were firstly the power of auxilium, i.e, the right of giving personal protection to any Plebeian against a magistrate, and secondly that of intercessio, the power of "coming between" or vetoing the action of a magistrate. Clearly it would be futile to confer these powers without securing that their exerciseshould beeffective. The tribunemust be protected in theexercise of his office and he must have the power to enforce his will in such a way that the magistrate cannot ignore or override it. Protection in the first instance was guaranteed by the Plebeian body, who took a solemn oath that they would show no mercy to any one who molested in any way the person of one of their officers. Later under the Valerio-H oratian Laws the inviolability of the tribune's person was guaranteed by the whole community under a religious sanction. The tribune was declared sacrosanct and anyone molesting a tribune became ipso facto an enemy of the community and its gods. ${ }^{10} \mathrm{~F}$ urther, in order to secure the enforcement of his decrees the tribune must inevitably claim the ius poenae, the power of punishment, as well as the ius auxilii, the power of protection, 


\section{W. R. Halliday, The Growth of the City State, 112}

for clearly thelatter could not be enforced against opposition without the former. In the early days of the tribunate this was vainly disputed by Patricians. Thus when Coriolanus was impeached by the tribunes, he contemptuously remarked that they were magistrates of the Plebeians only and had no right of punishment, but the impeachment none-the-less proved effective. In a strict sense, the story no doubt is unhistorical but it illustrates a constitutional fact. ${ }^{11}$

In 471 a change was introduced in the method of organisation of the Concilium Plebis. In what groups it originally voted is uncertain. ${ }^{12}$ Henceforward however it was divided into groups on the basis of thelocal divisions of the census and voted by tribes. Apparently Patricians opposed the change, though the reasons for their objection are not clear. The innovation, however, turned out to be of some importance, because the practice of voting by tribes in the Plebeian Assembly was imitated in a new Assembly of the Roman people, the Comitia Tributa, which cameinto existence at some date between 471 and $449 .{ }^{13}$ I $n$ this state assembly the groups are not based upon the principle of birth as in the Comitia Curiata nor upon that of wealth as in the Comitia Centuriata but upon that of locality. Further, although initially the functions of this assembly were probably of minor importance (chiefly the hearing of minor cases of appeal), they steadily developed because it was found more expeditious and convenient to summon the people by tribes in the city than to hold a meeting of the people under arms in the Campus Martius outside the walls.

The next crisis in the constitutional struggle was raised by the Plebeian demand for the codification of the law. In 462 a tribune Gaius Terentilius Harsa attacked the Patrician monopoly of the law. Opposition was stubborn; religious weapons were called into play. Sinister portents were reported and the Patrician keepers of the Sibylline Books interpreted them as a divine warning against internal strife. ${ }^{14}$ Eventually the Patricians were forced to compromise. In 454 a commission was sent to Greece to examine and report upon legal codes, particularly the famous laws of Sol on. It returned in 452 and thePlebei ans pressed for action. The Patricians yielded at the price of a temporary suspension of the constitu- 


\section{W. R. Halliday, The Growth of the City State, 113}

tion. In 451 the consulate, the tribunate and the law of appeal were suspended and a committee of ten (Decemviri) were given complete powers with the duty of drawing up and publishing a code. At the end of the year the work was unfinished and a new committee of ten was appointed to complete it. The details of events have become obscured by the picturesque and edifying legends, which have gathered round them, but it appears that the dominant personality on the first committee, the members of which were all Patricians, had been Appius Claudius. This noble for his own ends had courted Plebeian support and had succeeded in securing not only his own reappointment, but also that half of the new committee should be Plebeian supporters of his own. An attempt seems then to have been made to seize control of the state. The high-handed policy and, if legend may be trusted, the advantage taken by the Ten of the suspension of the law of appeal to commit individual acts of oppression led to a popular revolt. In 449 theP lebeians again seceded and again returned to Rome only upon their own terms.

Whatever were the political ambitions and crimes of Appius Claudius and his colleagues, they had done the work, for which they had been originally appointed, thoroughly and well. The Twelve Tables of the law which were now publ ished, remained the fountain head of all subsequent Roman law. "The code is thoroughly Roman in its caution and good sense, its respect for the past, which it disregards only when ol d custom violates therules of common sense, and its judi cious contempt for symmetry. Such a code as this might be changed in detail but was never likely to be repealed." ${ }^{\prime 15}$

The publication of the law was followed by the Valerio-Horatian Laws which reaffirmed the rights of the tribunate, and the inviolability of the persons of the protectors of the Plebs was now given a religious sanction binding upon the whole community.

The law of appeal was also reaffirmed with the proviso that no magistracy should in future be created from which there was no appeal to the Roman People, i.e. that the right of provocatio should never again be suspended as it had been by the creation of the Decemvirate. Finally provision was made that plebiscita, resolutions passed in the Concilium 
Plebis, might become binding not only upon the Plebeian Order but upon the whole Roman people. ${ }^{16}$

It will be noticed that up to the passing of the Valerio-Horatian Laws the Plebeians had been fighting for protection against political injustice rather than for the exercise of political rights. Thestruggle now assumed a different character. In 445 the tribune Canuleius passed the law which bears his name, permitting the legal intermarriage of Patricians and Plebeians. In spite of the scruples of religious prejudice, which the Patricians raised, this assertion of the social equality of the Plebeians was carried. Canuleius followed it up with the complementary claim to political equality and demanded that Plebeians should be eligible for the consulship. Round this crucial question the struggle raged until 367.

The Plebeian body by now consisted of two wings, the rich Plebeians who desired the right to hold political office and the poor Plebeians, who had no political ambitions, but whose grievances were economic. Of this the Patricians were able to take advantage and, by timely agrarian concessions, they were successful more than once in driving a wedge between the two wings of their opponents and so in prolonging the losing fight.

Their immediate answer to the demands of Canuleius was a compromise. While refusing to surrender the consulship they agreed that for consuls might be substituted military tribunes with consular powers. These were not to exceed six in number in any year and Plebeians were to be eligible.

They further attempted to forestall defeat by lessening the prize. In 443 the duties connected with the registration of the citizen body and thelevy were detached from the consulate and vested in new Patrician magistrates called censors. In 367, in the moment of defeat, praetors were appointed primarily to take over the judicial work which had previously fallen to the consuls. ${ }^{17}$

It is fair to notice that though these new creations were no doubt wel comed by the Patricians as diminishing the power of the consulship, of which they were proving unable to defend the monopoly, the increase in the number of magistrates was justified by the necessities of public 


\section{W. R. Halliday, The Growth of the City State, 115}

business which had now grown beyond the power of two individuals to handle with efficiency. The final phase of the struggle for the consulship opened in 377 when two tribunes, L. Sextius Sentinus and M. Licinius Stolo, united the Plebeian Order in support of a programme which combined political with economic proposals. Year after year their proposals were vetoed but year after year they were re-elected upon the same programme, which they wisely refused to modify, in spite of considerable pressure from a section of their own supporters to securethe passage of the economic reforms by abandoning the claim to the consulship. Eventually in 367 a settlement was reached and Camillus the dictator, who had acted as peacemaker between the Orders, was able to dedicate a temple to Concord. Consideration of the economic legislation, by which the support of the poorer Plebeians had been purchased, may be deferred to another chapter; the political measures, which became law, provided that there should be no more military tribunes and that in future one consul must be a Plebeian.

The surrender of the consulship was definitely the turning-point in the struggle for political equality. The assertion of the rights of Plebeians to hold other magistracies was merely a question of time. In 356 the first Plebeian dictator held office; in 351 a Plebeian became censor; in 342 a law was passed which enabled both consulships to be held by Plebeians; after 339 one of the censors must bePlebeian (not until 131 did Plebeians actually hold both censorships); in 337 the first Plebeian praetor was appointed.

The Licinian laws had also given the Plebeians the right to hold a religious office of some political importance. The control of the Sibylline Books, which had been exploited for purposes of obstruction by the Patricians, had originally been given to a committee of two, duouiri sacris faciundis. Licinius raised the numbers of the committee to ten, half of whom must be Plebeians. It may be noted that this was a well-chosen point of attack upon the Patrician monopoly of religious offices. The collection of prophecies of which tnis committee had charge were Greek not Roman, and the duties of the duouiri were concerned, not with the regulation of rites of Roman origin, but with the introduction and 
regulation of foreign cults, principally Greek. The claims of the Plebeians thereforeinfringed no immemorial rights of ancestral connection with the native religion of Rome.

Membership of this board proved but a stepping stone to the membership of the other great religious colleges of political importance. In 300 B.C. the number of augurs was raised from six to nine and those of the pontifs, who control led thereligious administration of thestate, fromfour to eight. ${ }^{18}$ The additional members in each case were to bePlebeians. The ol der priesthoods, it is true, remained Patrician, but they were politically unimportant. In political power the wealthy Plebeians had achieved equality of rights with the Patricians. They now shared all the greater political offices except one; the exception, the tribunate, was exclusively Plebeian. The acquisition of equality of political rights merged the wealthy Plebeians with Patricians in a new aristocracy in which for political purposes the distinction between the Orders had no longer any meaning. The interests of the wealthy Plebeians were now with the governing class and it is significant that the terms of the economic legislation, which had been necessary to secure the passing of the Licinian Laws were violated by Licinius himself. The support of the poor Plebeians was no longer necessary and, to an increasing degree, even the tribunes tended to losetheir primary character of protectors of the people and to become, like other magistrates, instruments of senatorial manipulation.

The popular bodies however gained some further powers. There were now three Assemblies of the Roman People: 1, Comitia Curiata, which had ceased to do morethan formal business; 2 , Comitia Centuriata, which elected the magistrates and was competent to pass laws; 3, Comitia Tributa, which now dealt with the bulk of legislation mainly because it was more convenient to summon than the Comitia Centuriata. In addition to these there was the Concilium Plebis. The three Assemblies could only be summoned by a magistrate of the state and not by a tribune; the Concilium Plebis could only be summoned by a tribune and not by a magistrate. The Concilium Plebis could not pass leges but only plebiscita, though some facilities had been introduced by the Valerio- 


\section{W. R. Halliday, The Growth of the City State, 117}

Horatian Laws by which pl ebiscita could bemade binding upon the whole community. In 339 further legislation, the actual terms of which it is not easy to deduce, extended the facilities for plebiscita becoming laws. ${ }^{16}$ In 339 and 338 it was also provided that the patrum auctoritas, i.e., the ratification by the Senate, which was a necessary condition of their becoming valid, should be given to resolutions and elections in the Comitia Centuriata before the actual voting on them in the Assembly began. Finally in 287 economic distress provoked a Third Secession of the Plebs, the fruits of which were the Hortensian Law. This made the Concilium Plebis an assembly of the Roman people. Henceforward a plebiscitum was on the same footing as a lex and consequently a tribune acquired the power to propose a law and became to all intents and purposes a magistrate of the state. Although he could not summon the Comitia Centuriata or Comitia Tributa but only the Concilium Plebis, the resolutions of the latter were now equally binding on the whole community with those of the former.

The contrast between the early development of the state in Athens and in Rome is instructive. We have two communities whose social organisation is, to begin with, very similar and whose languages are derived from a common parent tongue. Inevitably the early history of both was conditioned largely by the problems raised by the claims of wealth to political representation, and by the demand to be recognised as full members of the state by persons who were not members of the original hereditary clans, which formed the first community. The two histories present some similarities; the Servian reform, for example, is in appearancevery liketheSol onian. But the differences aresignificant and important. Solon's classification determined not only the degree of military obligation, but alsothequal ification for holding magistracies and for becoming a member of a body, with which lay the initiative in legislation, which enjoyed the powers of free debate, and which voted by individuals, whereas Servius conferred on the unprivileged classes membership of an assembly, which voted in groups, was completely dominated by the influence of the wealthy, was dependent upon the initiative of a Patrician magistrate, and lacked effective powers of 
W. R. Halliday, The Growth of the City State, 118

deliberation. In fact the history of the Struggle of the Orders illustrates the complete contrast of temperament and circumstance between Athenians and Romans.

Political ly themost essential differences liein therespectiveconceptions of the magistracy and in the peculiar character of Roman assemblies. Both in Rome and in Athens the powers, which had originally been possessed by the king, had come to be vested in annual magistrates. But whereas in Athens from the very start the process had been a division of the special functions of the king among individual magistrates with defined duties, in Rome the conception of imperium, complete and undefined executive authority, had been retained. The imperium of the consul was limited not by restriction or definition of function but by the existence of a colleague with equal powers. In Athens, from the time of Solon, the sovereign people claimed and exercised the right to call its magistrates to account at the end of their term of office. At Rome there was no similarly effective means of calling the magistrateto account. ${ }^{19} \mathrm{In}$ Athens the increase in the complexity and amount of business to be transacted was met by delegating the powers of the magistrates and of the aristocratic council to carefully organised popular bodies, which exercised deliberative powers. In Rome no systematic scheme of a constitution was invented nor imposed. Modifications took place piecemeal as events rendered them necessary. The increase of business was met mainly by the multiplication of magistrates, which was effected either by an extension of the collegiate system or by the creation of new magistracies. The magistrates retained complete control of the initiative in legislation and the popular bodies, though they increased in number, did not acquire the powers either of free debate or of individual voting.

As a result of this method of devel opment the constitution of the Roman Republic was a curiously complicated and clumsy instrument of government. After 287 there were no less than four popular assemblies all capable of passing legislation but all equally dependent upon the initiative of a magistrate. There were no less than 20 magistrates ( 2 consuls, 8 praetors, 10 tribunes), all of whom were equally competent to propose legislation and able to veto the actions and proposals of other 
magistrates. It was this division of the magistracy, with the resulting rivalry and dissension, which, in spite of the wide powers conferred by imperium, made the magistracy weak. This weakness was inevitably shared by the popular bodies, in as much as they were wholly dependent upon the magistrate. The real power consequently lay in the hands of the Senate, a body which now represented an official aristocracy in which the old distinction of Plebeian and Patrician had been lost, but whose patent of nobility consisted in the de facto hereditary occupation of the higher offices of state. Technically the register of this body was controlled by the censors but in practice their nomination was restricted by custom to the senior ex-magistrates available. ${ }^{20}$ The Senate in general character was therefore a permanent and experienced council of ex-magistrates. The election of magistrates, it is true, was carried out by a popular assembly but nomination had al ways been a factor in Roman el ections and, in fact, the voting was taken upon names submitted by the presiding magistrate. $^{21}$

The hereditary principlethrives naturally in a conservative society and actually the lists of chief magistrates ring the changes upon a comparatively small number of family names. The Roman Republic in fact had become an aristocracy in which the political power lay in the hands of a relatively small number of families, whoserved thestategeneration after generation in political office.

It was this aristocracy which steered the state through the crisis of the PunicWars, and it is important to notice that the patent of nobility which it recognised, the service of the state, implied a real sense of patriotism and a high standard of duty. It was not until the second century B.C. that senatorial rule began to degenerate into party misgovernment in the selfish interests of a single class.

Patriotism, conservatism and discipline were strongly ingrained in Roman character. These qualities were strengthened by the circumstances of a continuous struggle for existence against surrounding enemies and they were ultimately responsible for Rome's success. The legends of early Roman worthies, in which Livy delighted, though worthless as an historical account of events, provide illuminating 
evidence of what Romans thought of themselves and the qualities which they admi red. I ndustry, diligence, self-restraint, perseverance, manliness and the dignified seriousness of a steadfast purpose were the attributes of the ideal Roman. ${ }^{22}$ These virtues found their expression and their reward in the service of the Roman State.

The essential qualities of the Roman, his practical attitude towards affairs and his innate sense of duty to the state, reveal themselves in the history of the Struggle of the Orders. Parties may be as selfish as the factions in a Greek state in their desire to maintain monopolies or to pursue the interests of their class, but they are never prepared, as Greek factions were, to push the claims of their party beyond the point which would be fatal to the state as a whole. The oath of the Greek aristocrats "I will be an enemy to the people and will devise all the harm against them which I can ${ }^{123}$ represents an extreme from which the party warfare of early Rome was free. The one note of Greek faction is struck in the story of Coriolanus, and even here the characteristically Roman touch is the final awakening of conscienceand obediencetothecall of his mother's appeal, regardless of personal consequences to himself. It is impossible to imaginea similar appeal producing a similar effect upon an Alcibiades! It is true that the Patricians fought obstinately to protect their monopolies but whenever the struggle reached a crisis which obviously endangered the state, they faced the facts in a practical spirit and sought to find a compromise which would surrender the minimum necessary to secure a working arrangement.

A system of growth by the temporary adjustments of detail to emergencies as they arose produced, as we have seen, an unsymmetrical constitution. But clumsy and complicated as was its machinery it was enabled to function by the same practical and businesslike good sense, which had conditioned its growth. That it finally broke down in the first century B.C. was in no small measure the result of the influence of Greek civilisation upon Roman character and Roman politics. Directly the constitution was approached not as an imperfect instrument, which must be made to work as well as possible by means of legal fictions and the interpretations of common sense, but as a rigid system susceptible of 
W. R. Halliday, The Growth of the City State, 121

criticism and radical alteration, and statute in the place of custom was claimed to be the arbiter of political practice, the incongruities and fatal weaknesses of Roman political machinery becameapparent and thespi it of Greek faction, which knew no compromise, inspi red political parties in a relentless and mutually destructive struggle.

\section{Notes to Lecture VI}

1. Livy I, 54. Herodotus V, 92. For the general influence of Greek upon Roman historiography see Bury, The Ancient Greek Historians, pp. 224 foil. The first ten books of Livy are the principal source of our knowledge of the early history of Rome. Livy cannot be called a scientific historian. Indeed of ancient writers only Thucydides and Polybius deserve that title. Livy's own view of history, as stated in his Preface, is frankly ethical and his work is a great didactic epic in prose on the theme of the greatness of Rome. Although he consulted the historical works of his predecessors, he is not adequately discriminating in their use and indeed often displays a lack of interest in eliciting the truth from conflicting reports. He is more concerned "to point a moral and adorn a tale" than to achieve accuracy. "Heaccepted the tradition as he found it and shaped it in this (rhetorical and romantic) spirit not only without research but without any feeling for what we call historical truth." (Wilamowitz Greek Historical Writers, reprinted in Oxford Lectures on Classical Subjects, p. 4.)

The material provided by Livy's predecessors, all of whom were writing long after the events which they described, was lacking in the same qualities. Roman historical writing had begun in the period of the Second Punic War with the works of aristocratic nobles, who drew mainly upon family traditions. This explains such obvious examples of partiality as the consistent glorification of the Fabii or the equally systematic depreciation of the Claudii. J ust as Gibbon seriously considered the composition of the Decline and Fall in French, so Q. Fabius Pictor, themost considerabl eof theseannalists, wrotehis work in Greek. The historians nearer to Livy's own time were even less scrupulous than the early annalists and freely supplied their deficien- 
W. R. Halliday, The Growth of the City State, 122

cies of information with the flowers of rhetorical fancy. Of these Valerius Antias, who wrote the history of Rome from the foundation to the death of Sulla, was a prime offender. Although Livy was not blind to his inaccuracy, Valerius affords the groundwork to much of his history.

The chronology of the early Republic is of course traditional only. The official list of annual magistrates, Fasti Capitolini, was in itself a more or less arbitrary attempt to reduce confusion to order. The traditional dates however offer a conventional system which is adequate for our purpose. For a short summary of the difficulties connected with the chronology see Heitland, The Roman Republic I, pp. 63, 64.

2. As late as 63 B.C. A. Fuluius Nobilior exercised patria potestas to put his son to death on account of his complicity in the Catilinarian Conspiracy (Sallust, Catiline, 39).

3. Ridgeway upon archaeological and Conway mainly upon linguistic grounds have endeavoured to show that the distinction between Plebeians and Patricians is ultimately the racial distinction between a conquered and a conquering people. Both have sought to identify Plebeians with the Terremare peoples and Patricians with U mbrian (Villanova) inraders. Whether or not their general contention is sound, their suggested solution in detail is impossible. For a summary and criticism of their views see Peet, "Who were the Romans ? A note on somerecent answers," Annals of Archaeol ogy and Anthropol ogy, 1909, II, pp. 187 foll. Peet demonstrates two serious misapprehensions which vitiate their reasoning, (1) Both scholars assume that the peoples of the Terremare buried their dead; in fact they practised cremation. (2) Both are under the impression that the Villanova people were racially distinct from the Terremare people. In fact the Villanova civilisation is a developed continuation of that of the Terremare. As far as archaeol ogical evidence goes the co-existence of cremation and burial side by side in the cemeteries beneath the Roman Forum suggest that the inhabitants of the site of Rome were a mixed race at the beginning of the I ron Age. The wholevery difficult 


\section{W. R. Halliday, The Growth of the City State, 123}

and problematical question of whether the distinction between Patricians and Plebeians represents an original ethnological difference does not however greatly affect the struggle of the Plebeians for equality of political privilege. It is primarily a problem of the prehistory of I taly rather than of the history of Rome.

4. I uniores (18-45) were liable to full military service; seniores (45-60) were liable to be called out only for home defence. When he attained the age of sixty the citizen's liability ceased. He still retained his vote in the Comitia Centuriata, though it is said that the younger men complained of his being able to vote for a commander whom he would not have to serve, or for a war in which he would not be called up, and raised the cry that the sexagenarians should behurled from the voting gallery.

In Athens also military service ceased at sixty and the citizen army was divided into two dasses. But the age for full active service was higher, twenty to fifty; Socrates fought at Amphipolis in his forty-seventh year. The high age limit was no doubt made necessary by the size of the population in relation to military requirements. With the reservists (50-60) were classed the ephebes (18-19), who were undergoing training. This class was technically called "the old and young" (eg. Thucydides II, 13) and was normally liable only for garrison duty. It was with these home defence troops that Myronides won his victory over the Corinthians in the Megarid in 459/8.

5. According to tradition Servius created four tribes all of which lay within the circuit of the Servian wall. But it is not at all probablethat there was no land at all as yet in private ownership outside the walls of Rome. On the other hand the statement of Fabius quoted by Dionysius of Halicarnassus that Servius created twenty-six rustic tribes in addition to the four urban tribes is improbable. It is more likely that Servius created four tribes, whose boundaries extended beyond the city walls and included property outsidethem. Later when the "rustic" tribes were created, the Servian names were restricted to the city divisions. Probably there were four urban and sixteen rustic tribes in 471 B.C., when a new tribe was added upon the occasion of 
thenew voting arrangements in theConcilium Plebis. (SeeGreenidge, Roman Public Life, pp. 67, 68, 101.)

6. Originally there was no right of appeal from the dictator though eventually this extraordinary magistracy was brought into line with the normal magistracies in this respect and probably the lex Valeria of 300 B.c. establ ished the right of provocati o from the dictator within the city.

During the last century of the Republic when the dictatorship had ceased to exist, (for though Sulla and lulius Caesar assumed the title of dictator neither was a dictator in the true sense of the word), the senate claimed the power of temporarily suspending the constitution by the senatus consultum ultimum. By this decree the consul, as the executive of the state, was instructed "to see that the commonwealth came to no harm." It was claimed that in fact this decree was equivalent to a declaration of martial law and gave the magistrate unrestricted powers to take any necessary action. The popular party on the other hand consistently disputed the competence of this decree to suspend the right of provocatio. This constitutional point was at issue in the question of the legitimacy of Cicero's treatment of the Catilinarian conspirators, and it furnished Caesar with the political weapon by which he was able to secure Cicero's banishment.

7. At sometime during the first three centuries of the Republic Plebeians came to be admitted to the Comitia Curiata but probably this did not happen until the real power had passed to the Comitia Centuriata. (See Greenidge, op. cit., p. 88).

8. "The essence of this reform is in fact the recognition of equality of rights in landed property" (Greenidge, op. cit., p. 65).

9. No assembly of the Roman People possessed the power of free debate. For the contio, which normally preceded legislation, can hardly be so described. In this the presiding officer explained the rogatio and such prominent citizens as he cared to introduce (dare contionem) expressed their views. (See Greenidge, op. cit., pp. 160, 257.)

10. After 23 B.C. Augustus made the tribunicia patestas the most prominent feature of the aggregate of powers detached from offices, 


\section{W. R. Halliday, The Growth of the City State, 125}

which gave him defacto the control of the state, while permitting him to preservethe forms of a constitutional republic. From the possession of the tribunician power followed the sacrosanctity of the emperor's person, and upon this was based the law of treason. Thus, what had originally been conferred to secure the person of a protector of the people, became eventually the justification for a reign of terror by a Nero or a Domitian.

11. "Contemptim primo Marcius audiebat minas tribunicias; auxilii, non poenae, ius datum illi potestati; plebisque, non patrum, tribunos esse" (Livy II, 35, cf. Livy II, 56 where Appius Claudius insists that "the tribune had no jurisdiction over anyone except a Plebeian : for that he was not a magistrate of the people in general but only of the commons.") Coercitio, the power of enforcing his decrees, was the necessary logical complement to the tribune's negative powers. (See Greenidge op. cit. pp. 94 foll.) F or the nature of the magistrates power of coercitio and the degree of its limitation by the right of appeal see Greenidge, op. cit., pp. 167 foll.

12. It is quite uncertain how the Concilium Plebis was originally organised for voting. Livy is not alone among classical authors in supposing that previously to 471 tribunes were el ected by the Comitia Curiata, and he attributes $(\mathrm{II}, 56)$ the Patrician opposition to the fact that the change to a system of tribal groups prevented the Patricians from exercising influence on the elections through their clients. The other classical references for this view will be found in Botsford (The Roman Assemblies, p. 262), who is prepared to accept their implication. The generally accepted view, however, has been that it is impossible to believe that the Plebeian officers should ever have been elected by the Comitia Curiata. Mommsen suggested that themistake arose because the Concilium Plebis was in the first instance modelled upon the Comitia Curiata and voted curiatim. (SeeGreenidge, pp. 94, 101 with the notes.) But though possible this is at best a guess and is not devoid of difficulty. I f we reject, as personally I think that we must do, the view of Livy, the safest answer to the question how did the Concilium Plebis originally vote, is that we do not know and have no 
W. R. Halliday, The Growth of the City State, 126

means of finding out. (Heitland, Roman Republicl , p. 67.) F ortunately the insol uble question is not of major importance. A period of at most 23 years is involved for after 471 the Concilium Plebis of course Toted tributim.

13. The generally discredited view that the law of 471 replaced the Concilium Plebis, which therefore ceased to exist, by the Comitia Tributa, has been revived by Botsford, op. cit., pp. 119 foll., whose main argument is that the distinction drawn by M ommsen, and before him by Roman jurists, between the meaning of the words concilium and comitia is largely unreal. The evidence for the usual view that the Comitia Tributa Populi Romani did not replace but existed side by side with the Concilium Plebis is summarised in Greenidge, op. cit., Appendixl, pp. 445 foll. Eventually in 241 the Comitia Centuriata was remodelled on a tribal basis.

14. Livy III, 10.

15. See Greenidge, op. cit., p. 104.

16. Three laws (1) Valerio-Horatian 448 B.C. (Livy III, 55), (2) Publilian 339 B.C. (Livy VIII, 12), (3) Hortensian 287 B.C (Pliny, Nat. Hist X 37) are described in practically identical terms and the purport of each is represented as giving plebiscita a force binding upon the whole community. It is certain however that the Publilian and Hortensian laws are not merely repetitions of the Valerio-Horatian, that a plebiscitum did not in fact become equivalent to a lex before 287 B.C., and that these three laws represent stages in a gradual process. In 456, not long before the Val erio-H oratian legislation, a tribune l cilius had secured the passage of a plebiscitum into law. The procedure necessary was to present the plebiscitum to the consuls and senate and to induce them to bring it before the Comitia Centuriata. In this particular case I cilius had been obl iged to compel the consuls to bring the plebiscitum before the senate by threatening them with arrest. Strachan Davidson has suggested that the Valerio-Horatian law now madeit obligatory by statute upon the consul to bring pl ebiscita before the senate if required to do so. (Smith, Dict. Antiquities S.v. plebiscitum, II , pp. 437 foll.) Greenidge on the other hand holds that it merely 


\section{W. R. Halliday, The Growth of the City State, 127}

affirmed theright of the Plebeian corporation to make valid bye-laws. "A law which is valid for a corporation is valid for those outside the corporation.... All self-regarding ordinances of the Plebs bound the Plebeians in the first degree, the Patricians, if it infringed existing rights, in the second degree" (Gieenidge, op. cit., p. 110.) The Publilian Law "possibly expedited matters by striking out the intervening consultation of the senate and may have required the consul to bring the petition of the Plebs at once before the Populus." (Strachan Davidson, loc. cit.)

17. That the praetorship was originally a Patrician magistracy is theview of Livy $\mathrm{VI}, 42$. It is possible, however, that this may be a deduction from the fact that it was not actually held by a Plebeian until 337 B.C. Whether in thefirst instancethe office was definitel y restricted by law to Patricians is not certain. (Greenidge, op. cit., p. 120.)

18. The board of Pontifices, who had complete control of religious administration, had originally consisted of the king and four Patricians. After the fall of the monarchy the king's seat on the board was not filled and the coll ege consisted of four Patrician members. Of these the chairman, pontifex maximus, succeeded to the royal prerogatives in religious administration. His official residence was the Regia and he nominated the Vestal Virgins and the holders of the greater priesthoods

In 300 B.C. the college of augurs consisted of four members. Livy, according to whom the proper number must always have been divisi ble by three, accounts for it by supposing that two had died (Livy $X, 6)$. An alternative tradition supposes that there were originally three augurs, Numa added two and of this board of five the king was a member. It is then supposed that on the expulsion of the monarchy the king's seat upon the augural, as upon the pontifical board, remained vacant and thus there came to be four augurs in 300 B.C.

19. It is true that Roman magistrates could be accused by the tribunes before the Plebs (see Greenidge, op. cit. p. 182) but the occasional exercise of this power is not comparable to the regular and direct control of the magistracy by the Athenian peoplethrough the Popular 
W. R. Halliday, The Growth of the City State, 128

Courts.

20. The regular procedure maybe illustrated by the measures taken in 216 B.c. to fill up the senate, which had been exceptionally depleted by theappalling losses at Cannae. First thosewereappointed who had held curule office since the last census but had not yet become senators, next those who had been aediles, tribunes or quaestors but had not attained curule office, and lastly private persons of recognised merit (Livy XXIII, 23). Normally of course the ex-magistrates were sufficient to fill the vacancies.

21. See Greenidge, op. cit., p. 185. At an election the presiding magistrate had the power of scrutinising the list of candidates and disqualifying the unworthy before submitting it. Further an election was not valid until the name of the successful candidate had been formally announced by the presiding officer (renuntiatio). Even after the votes had been taken it was ther efore within the power of the president to refuse to announce and thereby to quash the election of a candidate whom he considered unsuitable.

22. See Warde Fowler, Rome (HomeUniversity Series) pp. 12 foll.

23. Aristotle, Politics V, 9, II, 1310a. 
Lecture VII. The Land Question.

The ideal of the city state always presupposes an agricultural basis of society. This ideal does not invariably correspond with fact, though universally the right of owning land was restricted to citizens. Corinth from early times was primarily a commercial state; ${ }^{1}$ Megara, with its limited territorial area, was largely industrial and dependent for its prosperity upon the manufacture of woollen goods and the export of salt. ${ }^{2}$ It remains true, however, that in most of the city states of Greece in the sixth and fifth centuries B.c. the middleclass, which formed the backbone alike of the political community and of the army, consisted of small landowners - the zeugite class of the Sol onian census, i.e, the men with a yoke of oxen, who fought as heavy armed infantrymen in the citizen army. Early Rome was similarly a community of peasant farmers and a Cincinnatus summoned to take control of the state is found in his shirtsleeves guiding the plough upon his little farm.

Both in Greece and Rome changes of political, commercial, and social conditions tended to the el imination of the peasant proprietor. In Athens the sailor democracy of Salamis and the urban proletariat of a commercial and imperial state were ready to ignore or to sacrifice the interests of the agriculturalists whom they had supplanted in political importance, while the Peloponnesian War by the ruin of agricultural industry in Attica completed the downfall of thesmall-holder. In I taly theH annibalic War similarly ensured the disappearance of the peasant proprietor, whose importance had al ready been diminished by competing economic interests.

But both in Greece and Rome it was felt that by the disappearance of thesmall farmer thestate had suffered an appreciableloss. Politically the sober senseand conservative patienceinnate in cultivators of thesoil was a steadying influencemuch missed in ages of democratic extravagance or of reckless political panaceas and revolutions. ${ }^{3}$ M orally the di sappearance of a class with a homely but real standard of duty was a serious loss to 
the community. ${ }^{4}$ Physically an open-air life which unlike the sedentary occupations of industry did not cripple the physical development of the individual, ${ }^{5}$ had produced healthy citizens. The peasant proprietors had formed the flower of the citizen armies; ${ }^{6}$ these were the men who had fought at Marathon and had conquered I taly for Rome. Both in Greece and Rome, therefore, the disappearance of the peasant proprietor was bitterly regretted by practical politicians as well as by political theorists. In the Athenian reaction against the urban democracy, which had so signally failed in the struggle with Sparta, the remedy proposed by the moderatereformers was torestrict thefranchisetothehoplitecensus and to give the land owning middle class the preponderance in the state. The party of the Gironde in times of revolution is invariably at the mercy of the J acobins; the policy of Theramenes and the moderates had never a sufficient test of practice. But it is clear that the sanest of Greek political thinkers were favourable to it, and the conduct of the moderates during the few months of their direction of the state after the fall of the Four Hundred, extracts from Thucydides one of his rare personal comments. ${ }^{7}$ Aristotle, too, considered that "the best material of democracy is an agricultural population": "when the class of husbandmen and of those who possess moderatefortunes havethe supreme power, the government is administered according tolaw. F or the citizens, being compelled to live by their labour, have no leisure and so they set up the authority of the law and attend assemblies only when necessary. ${ }^{\prime 9}$ In Rome the Gracchi tried in vain to recreate a citizen peasantry and Vergil and Horace bear witness to the aspirations of Augustus. Economic forces, however, were against the reformers and the system of large estates remained to prove the ruin of I taly. ${ }^{10}$

The land question in antiquity may be divided into three different phases. In the first the state is primarily agricultural, but theincrease of population has had the natural result that the area of land available for cultivation is no longer sufficient for its needs. The other two phases are primarily concerned with rival systems of land tenure and the tendency for the small proprietor to be crowded out of existence by the growth of large estates. In the second phase the peasant class is still in existence 


\section{W. R. Halliday, The Growth of the City State, 131}

though hard pressed by economic conditions and the aim of the reformer will be to alleviate existing distress and to secure conditions which will make it possible for the peasant proprietor to survive. In the third phase the small-holder has ceased effectively to exist and the aim of the reformer is to recreate a peasant class.

The first phase of the problem is very simple alike in its causes and its remedies. It arises from the obvious fact that while population increases in numbers, the land of the community does not increase in area. As long as society remains purely agricultural and lives solely from the land, a disproportion between the number of mouths and the available source of supply can only beremedied in two ways; either the amount of land must be increased or the number of mouths reduced.

Sparta will afford a good example of the problem in its simplest terms and thesolution by expansion. TheSpartan stateconsisted of a privileged soldier class, who held by force their position of political predominance over an enslaved population of superior numbers. Each citizen soldier held from the state an allotment of land for his support. This allotment was inalienable and was worked for him by serfs (helots) who were the property of the state but the use of whom was allotted by the state to the individual. The serfs provided one-half of the produce of the holding for the support of the master, whose practice of the military profession was thus unhampered by the claims of agriculture. Clearly this rigid system implies one inalienable land lot for one citizen and when the number of citizens increases there will not be sufficient land lots. At the same time, although it is true that early Sparta did send out some colonies, her peculiar military needs will make her loth to lose citizens and sol diers by emigration. The alternative for a military race is expansion by conquest and, in consequence, in the eighth century B.C. Sparta crossed the range of Taygetus and embarked on the conquest of the fruitful Messenian plain, which provided her with more land for more holdings, while the conquered inhabitants supplied the slave labour to work them. In the early history of the Roman Republicland hunger was a no less important factor and relief was largely provided by conquest. In the Struggle of the Orders the cry of the poor Plebeians was for land, and relief reluctantly 


\section{W. R. Halliday, The Growth of the City State, 132}

wrung from the privileged classes was afforded chiefly by the land made available by conquest. In fact until Rome had conquered the whole of Italy and there was no further expansion possible, it was the relief afforded by the acquisitions of conquest rather than legislation which prevented the land problem from breeding revolution. ${ }^{11}$ While an increasing disproportion between the area of Iand available and the number of mouths to feed was universal, the solution of expansion by conquest was for obvious reasons not universally possible. Theal ternative is the relief of the pressure of overpopulation by emigration, either in its Arcadian form $\mathrm{m}^{12}$ or in the more organised form of colonisation The agricultural character of the earlier colonial settlements is proof that the primary motive of Greek colonisation in its early stages was the land hunger consequent upon over-population at home. ${ }^{13}$ The development of commerce further relieves pressure by providing an alternative and indeed more profitable method of earning a living. Land is consequently no longer the sole economic source of supply and the second phase of the land problem, which is essentially a feature of the transition stage from agriculture to commerce, will then present itself.

The general causes, social political and economic, leading to the distress of the eighth and seventh centuries in Greece have already been indicated. As regards theland thesituation is, briefly, that theinstitution of private ownership has been followed by increasing inequality of distribution. The division of property among heirs creates holdings too small to be farmed on a sound economic basis. Either thesmall owner will be compelled to sell direct to the big landl ord or he will need to borrow from him in order to tide over the bad years and so fall deeper and deeper into his debt. The land problem, as it now presents itself, consists of the competition between two forms of land tenure, the small holding and the large estate and it may be well, before considering the particular examples of the problem as they affected Athens and Rome, to beclear as to certain general features, which are universally true. Theland to which the small hol ding system can most suitably be applied is rich soil near a good market. The size of the holding which can be profitably farmed varies inversely with the fertility of the soil and the degree of agricultural 


\section{W. R. Halliday, The Growth of the City State, 133}

skill employed. Wherethe crop is light, the larger holding with the bigger turnover is economically more sound. Very poor land is of course most suitably used for pasture. A point may be mentioned here which is of some importance both for Greek and Roman agriculture. The quality and productivity of land itself depends I argely upon proper care and continuous cultivation. Without these land tends to "go back." It is surprising how quickly in the hill country a neglected field will revert to moorland. It follows that the interruption of agriculture and still more the damage caused by war or enemy occupation may produce more than temporary effects. A part from the other difficulties of the problem, the farming land of I taly was actually less suitable for cultivation by peasant proprietors in the time of the Gracchi than it had been before the Hannibalic War.

Economically the small farmer has greater difficulties than the large farmer because his margin is less. All farming is largely dependent upon the forces of nature the action of which can neither be controlled nor foreseen except in a rough and ready fashion. ${ }^{14} \mathrm{~A}$ bad harvest or a succession of bad harvests may occur through no fault of the farmer. Obviously the large mixed farm has here an advantage in the matter of security. The turnover is larger and there is a larger margin of profit whilea simultaneous failure of different kinds of crops is improbable. The small man, however, without capital is at the mercy of fortune; a single bad harvest may ruin him nor, if he clings to his land, is his condition likely to improve unless he can raise capital to spend upon its cultivation for the following year. For those who put nothing into the land will get but little out of it, and land deprived of the proper care itself progressively deteriorates.

Now small farming may exist under two systems. Either the smallholder is the tenant of a landowner or he is himself the proprietor. The position of the tenant is in some ways less unenviable in time of need. A good landlord may allow his rent to stand over and even advance him money to meet the expenditure necessary for the proper cultivation of next year's harvest. Apart from sentimental motives, it is not to the landl ords' interest toallow theland to deteriorate for want of proper care. But it cannot be denied that the small tenant is economically at the 


\section{W. R. Halliday, The Growth of the City State, 134}

mercy of his landlord and he has not, of course, the security of tenure of the peasant proprietor. The small proprietor, however, with whose position the student of classical antiquity is mainly concerned ${ }^{15}$ is really in a worse position. His only refuge in financial difficulty is the usurer. The money lender has no interest in the condition of the farm and, particularly in early classical times, the laws of debt were savage in their severity. In general it may be said that in a developed society the economic basis of which is industrial or financial, except under very special conditions, ${ }^{16}$ the economic forces are on the whole inimical to the system of small farming, however desirable it may be upon moral or national grounds to create a class of peasant proprietors. It should be noted that both in the ancient and the modern world the motives of land reformers, who aim at the preservation or creation of the small holding system, have not been economic in character.

In the last half of the seventh century B.C. Attica passed through a period of severe economic distress, which was accentuated by the long and unsuccessful war with Megara. When Solon took over the control of the state he found that the land of Attica was being absorbed into large estates and the peasant proprietors were being converted into a species of tenant serf. The soil of Attica is poor and there is but a light crop. The methods of cultivation were primitive; there was no system of rotation of crops and land cropped one year had to lie fall ow the next. Even in good years the margin of profit from the small holding cannot have been large. A bad year, if the farmer does not sell outright, necessitates borrowing capital with which to carry on and borrowing necessitates security. The only security he has to offer are his farm or his labour, for in ancient times the debtor's last security was his person. The result was the emergence of two oppressed classes, persons who had been seized for debt and sold as slaves by their creditors, in some cases out of the country, and a class called hektemoroi (sixth parters) who farmed the holdings which had been originally their own, as tenants of the rich creditor, paying him one-sixth of the produce. Aristotle tells us that in case of arrears of rent these too were liable to be sold into slavery. The small land-owner was further injuriously affected by the encroachment of the nobles upon the 


\section{W. R. Halliday, The Growth of the City State, 135}

common land. Clearly Solon's mission as a reformer implies two allied problems : I, the remedy of existing abuses; 2 , the provision of a sound basis for the future.

The popular cry was for a redistribution of land, but Sol on was too wise and moderate a reformer to approve a measure so revolutionary in itself, and so vicious as a precedent. The case of the debtors however called for immediate treatment. Citizens who had been sold into slavery were redeemed and the law permitting the borrowing of money upon personal security was repealed. F or the future it became illegal for the creditor to seize the person of the debtor and sell him as a slave. The condition of those who had held precariously to their freedom but were hopelessly involved in debt, also demanded attention. A radical measure which would be impracticable in a more highly devel oped soci ety, afforded rel ief. Existing debts were cancelled. Changes introduced in the currency and in the system of weights and measures may also have benefited the lower classes. Further legislation was introduced to prevent the accumulation

of landed property in the hands of a few large estate owners. The demesnes of the nobles were probably restored to their original size by the removal of the boundary stones, which marked the encroachment on the common pasture ${ }^{17}$ and a law was passed limiting the size of future holdings. ${ }^{18}$

The existing economic crisis having been relieved and the recurrence of its causes to some extent averted, the permanent trend of the economic development of the country had to be considered. Solon seems to have grasped the principle that, where local conditions involve the production of necessaries at an economic disadvantage, thealternative is to buy such necessaries from outside, paying for them by the increased production and export of commodities to the cultivation or manufacture of which Attica was more suited. In consequence he encouraged the cultivation of the olive to which, unlike corn, the conditions of Attic farming were favourable. The increased export of oil will then more than pay for the importation of foreign corn. He seems also to have seen that a state's financial position is dependent upon the amount of its production and that therefore the general development of commerce must be assisted. 
Hence one of his laws provided that every Athenian must learn a trade or profession. ${ }^{19}$ The character of his currency reform has been disputed. It is known that Solon altered the standard of Athenian currency from the Aeginetan to an approximation to the Euboic standard. The Aeginetan mina contained 100 drachmae, whereas the new mina contained 70 , and it was suggested, even in antiquity, that the motive of the change was the relief of debt, inasmuch as those who paid debts in the new denomination of coin were repaying in actual value at a reduction of 30 per cent. In other words, that the change was simply a debasing of the currency. This view is supported by Professor Percy Gardner, who links with it a changein the Pheidonian standard of weights and measures and points out that the result of the two changes on a practical transaction would be, that the purchaser was paying less in actual as opposed to nominal value and was recei ving more in quantity. Thechange, however, can hardly lack a more fundamental commercial and political motive. At the outset of the development of Athenian trade, it breaks with the system of Aegina, thegreat commercial, and therefore hostile, rival which lies across Athens' gateway to the sea, and links itself with the rival currency standard of Euboia and Corinth. ${ }^{20}$

The land reforms of Sol on were completed by Peisistratus, whose policy it was to maintain a contented peasantry. By the improvement of roads and communications and by the establishment of a system of judicial circuits in the country districts he did much to organise country life on a sound basis, while the stories of the tyrant's tours of inspection in Attica are evidence of the personal interest which he took in the welfare of the agricultural industry. ${ }^{21}$ But the most important of his reforms was the financial provision of a sound economic basis to the small holding system which gave reality to the Solonian land reform. The great material prosperity of the Greek states under the rule of the tyrants is primarily due to the wise use of capital, which became concentrated in the hands of a single authority. Peisistratus was in a fortunate position, for besides the profits of the sequestrated property of political enemies, the silver mines of Thrace and those of Laurium, which were first developed and worked under the Peisistratids, supplied him with capital. Part of this 


\section{W. R. Halliday, The Growth of the City State, 137}

was applied to agriculture. Capital was advanced to the small-holder by the state in return for a tax of moderate dimensions and in this way the farmer was relieved of the necessity of falling into the hands of the usurer. ${ }^{22}$ The policy was justified by success and the peasant proprietor seems to have flourished in Attica until the Peloponnesian War.

In Rome similar economic causes produced similar results leading to very similar remedies though the problem of the small-holder was complicated by becoming involved in the Struggle of the Orders. We have traced on its political side the history of the struggle of the unprivileged Plebs with the privileged Patricians, and at least in the final stages of the conflict, the victorious order consisted of two wings, the rich Plebeians who desired the right of holding political office and the poor Plebeians whose needs were primarily economic. It was only by combining the two parties in a common programme that victory was eventually secured.

The economic grievances of the small plebeian land-owner were very much the grievances of the small proprietor in Attica, aggravated by a state of constant warfare and by the unfair division of the spoils of conquest on the part of the privileged class. The menacing growth of large estates and the severity of the laws of debt are the objects of the Licinian as of the Sol onian legislation. In considering the condition of the Plebeian small-holder the constant warfare of the early Republic must be remembered. The economic stress produced by war necessarily tells hardest upon the poor, and the small farmer called upon to neglect his holding in fulfilment of the demands of military obligation must often have returned from a campaign to find his affairs disastrousl y involved. ${ }^{23}$ The neglect of his private interests in the service of the state not infrequently brought slavery as its reward, for the usurer in Italy as in Greece had power to seize his debtor's person if his claims were not paid in full. Further the spoils of conquest were distributed by the privileged class. The land, conquered by the armies in which the poor Plebeian served, was to a great extent reserved for Patrician squatters. F rom time to time a division of public land among the poorer classes was reluctantly wrung from the ruling caste as a concession, in order to allay discontent which might necessitate the surrender of political privileges. But 


\section{W. R. Halliday, The Growth of the City State, 138}

whenever the two wings of thePlebeian party fail ed to combine, land bills were blocked by political action, and it is only when the order drew together and the political programme of therich Plebeians was supported by the poorer members of the Order that the Patricians endeavoured to split the party by agrarian concessions. This is the real motive of the allotments of public land made between the second Secession and the Licinian Laws.

The Patricians used agrarian concession simply as a political instrument. If the worst came to the worst they were sooner prepared to sacrificetheir monoply of theager publicus than their monoply of pol itical privilege. Their own political motives they attributed to others and, rightly or wrongly, individual reformers who agitated for the relief of the poor were suspected of monarchical ambition. Thus Spurius Cassius was put to death in 486, Spurius Mallius in 439 and M. Manlius, the saviour of the Capitol, in 384. Whether their motives were suspected with justice or not, it clearly did not mitigate the bitterness of the poor man's feel ings that the champions of his cause were treated as the enemies of the state.

The Licinian Laws, carried after ten years' struggle in 367 B.C., aimed at the relief of debt and the limitation of large estates. Interest already paid was to be deducted from the principal and the remainder to be paid off in instalments within three years. This measure afforded immediate relief to those at the moment in the usurer's clutches. Holdings of public land were not in future to exceed 500 iugera, and the number of sheep and cattle which any individual might graze upon the common pasture was limited by law. It is possible but improbable that a third clause protected the free labourer against slave competition by providing that a

proportion of the labour employed upon any estate must be free. It seems very doubtful, however, if the use of slave labour had at this time assumed the suggested proportions in Roman agriculture. Slavery was still in Mr. Heitland's phrase "a family institution not an industrial system" and it is probable that the historians have transferred the conditions of their own times to earlier days in which they did not apply. The Licinian Laws did not in fact settle the small-hol ding problem in I taly; this was dueless to any inadequacy in their provisions than to non- 


\section{W. R. Halliday, The Growth of the City State, 139}

observance. The rich Plebeians followed the Patrician example in regarding the land question as simply a political weapon. For them the economic clauses of the Licinian legislation had been merely the means of securing the support of the poor for their political claims. Once the latter had been attained, their interests lay not with the small farmer but with the governing classes. As a result the limitation of the size of properties became rapidly a dead letter and one of the promoters himself is said to have violated the provisions of his own law. It was the continued expansion of Rome in I taly rather than economic reform by legislation, which prevented the land problem from developing revolutionary proportions.

Both in Attica and I taly rival economic interests robbed agriculture of its pre-eminence in the state and in both war completed the ruin of the small-holder. The victory of Salamis inaugurated the sail or democracy at Athens, whose interests stifled those of the hoplite middle class, the heroes of Marathon. The devel opment of commerce and capitalism was stimulated by Persian booty and the spoils of empire. Imperial and commercial interests no doubt made inevitable the war with the Pel oponnesian League, but it was a war in which the agricultural classes had everything to lose and nothing to gain. It is not perhaps surprising that they remained cold to the glamour of imperialism and bitterly opposed to war. The strategy necessarily imposed by the weakness of Athens on land and her strength at sea involved the sacrifice of rural Attica to theenemy. The highway of the sea remained open and thesailor proletariat continued to profit by the wages of naval service or the gains of maritime commerce. F or Sparta was too weak a naval power to make her "ruthless sea warfare" a serious or effectiveweapon. ${ }^{24}$ Thesmall landowner on the other hand was brought into the overcrowded city to find quarters, where he could, in temple precincts, between the Long Walls, in gutters or on the battlements. The plague decimated the country population living under such conditions. Upon the small farmer fell the ill paid burden of hoplite service, and the garrisoning of the walls from which he must watch the destruction of his vines and crops by the invader whom he dared not face in the field. The damage to agriculture 
in the Archidamian war was as nothing to the devastation caused by the Spartan occupation of a permanent fortified post at Deceleia, which resulted in the destruction of trees and buildings, as well as crops, and the wholesale devastation of the land. ${ }^{25}$ The war ruined the agriculture of Attica ${ }^{26}$ and transformed Athens into a purely industrial and commercial state, in which wealth became more and more unevenly distributed and slave labour increasingly victorious in its competition with free. Ruined properties glutted the market with cheap land, and rich persons like Ischomachus and his father invested their capital in the formation of largeestates worked by slaves under an overseer. In the fourth century the peasant proprietor has, in fact, ceased to bean important constituent factor in the body politic. ${ }^{27}$

In I taly the devastation of the Hannibalic War, the enormous influx of slavelabour and capital, which resulted from Rome's successful wars, and the attractions and excitements of urban life in a large cosmopolitan metropolis combined to eliminate the peasant proprietor. Many small farmers had been ruined in the war, the agricultural value of the land had deteriorated through actual damage by hostile action and the enforced neglect of its cultivation. ${ }^{28}$ In consequence land was cheap and the capitalist had the opportunity of building up a large estate which could be economically farmed by gangs of slaves ${ }^{29} \mathrm{~F}$ rom the point of view of the state, no doubt the disappearance of the small proprietor involved the loss of a source of strength to the community, and the substitution of plantation slavery, a potential source of armed disorder, ${ }^{30}$ was not in the public interest. The conditions of the age however, had made the change inevitableand economically the small farmer could not compete with the capitalist land-owner. Rural I taly became depopulated ${ }^{31}$ and slave barracks took the place of peasants' cottages while the free population drifted to the town to form a rabble of mean whites. This was the spectacle which moved the generous enthusiasm of Tiberius Gracchus. "The savage beasts in I taly," he said "have their particular dens, they have their places of repose and refuge; but the men who bear arms and expose their lives for the safety of their country, enjoy in the meantime nothing more in it but the air and light."132 


\section{W. R. Halliday, The Growth of the City State, 141}

It became the object of his life to recreate a free citizen peasantry, but the problem which he set himself differed to an extent which he hardly realised from the problem dealt with by Solon or Licinius Stolo. The task of the earlier reformers had been to relieve the distress of an existing class and to make provision against the recurrence of its causes, that of Gracchus was to resettle an urban proletariat upon the land. The fundamental difficulties of such a scheme were, firstly that there was no land availablefor distribution without the disturbance of vested interests and the customary rights of property, and secondly that there was no longer a peasant class. The first proved the main political difficulty which led to the failure of the scheme, the second would have doomed it in any case. Experience does not confirm the optimistic view of land-reformers in all ages, that any fool will make a good farmer or that the type which goes under in the struggle for existence in the city will become industrious and efficient if planted on a country holding.

But it is true, not only that the land of I taly was wastefully and badly farmed under a system of absentee landlords and dishonest slave stewards, ${ }^{33}$ but al so that Tiberius Gracchus was right in thinking that the agricultural condition of the country was mainly responsiblefor thesocial evils of the day. He was wrong however in thinking that matters could easily be put right by legislation. The Gracchan scheme of Iand reform proved in fact a complete failure. It is true that its defeat was due in part to political causes, which did not allow it a fair trial, but it was in any case doomed to failure on its merits.

The issues raised in the struggle between the land reformers and the vested interests shook the Roman constitution to its foundations, and formed the prelude to that period of disintegration and anarchy of which the establishment of autocracy proved in the end the only possible cure. But with the political and constitutional aspects of the matter, important though they are, we are not immediately concerned at the moment.

Tiberius Gracchus becametribune in 133 B.C., and brought in a measure to provide all otments in I taly for poor Roman citizens. In order to secure the necessary land he was compel led to assert the claim of thestate to the ownership of "public land." N ow the greater part of the land, which had 


\section{W. R. Halliday, The Growth of the City State, 142}

from timeto time been acquired by the conquests of the Roman state, had been parcelled out in allotments to citizens or colonists and had consequently become private property, but all that had not been so distributed remained technically ager publicus populi Romani. This publicland had been treated in two ways; either it had been let out to tenants of the State, eg., the Campanian land, or it had been granted to possessores or squatters, who, in return for a nominal quit-rent, were allowed to settle on the land, develop it and effectively occupy it, though technically it remained the property of the State. The first kind of public land brought in a steady income to the State, which it would be impolitic to touch, but Gracchus determined to secure the land required for his allotments by reviving the undoubtedly legal claim of the State to the ownership of the squatters' land. The Licinian Laws, though their provisions had never been observed, had limited the holdings of public land, which any individual might enjoy, to 500 iugera. This provision with minor concessions, some of which were subsequently withdrawn, Tiberius determined to reviveand enforce and to distributetheland thus acquired in inalienable allotments of 30 iugera.

There is no question that the State had a legal right to this land, but legal rights are not always equitable. Tiberius' contentions were as indisputable as the statements of modern politicians that some of the large properties in this country were originally acquired some centuries ago by the spoliation of the monasteries, the enclosure of common lands or in other nefarious ways. It is however fair to recognise that there was more than the selfish greed of vested interests behind the outcry which the proposal of Tiberius raised; there was a sense of real injustice. In actual fact the State had allowed its rights in this kind of property to become dormant over a great number of years. By usage, land which had originally been held under a squatters' tenure had consequently come to be looked upon as private property and had freely changed hands as such. The actual owner or his immediate ancestors had, in many cases, bought the land and whatever had been the tenure of the original possessor, as far as he was concerned it represented a legitimate investment. It was natural enough that the Gracchan scheme should have been regarded by 
many as a revolutionary attack upon the security of property. Nor was it only Roman land-owners who were affected. The capitalists and joint stock companies were not without an interest, for such landed property had been freel y mortgaged; grants of land upon the tenure of "possession" had also been made to I talian allies.

Tiberius succeeded in over-riding opposition at the ruinous cost of removing a colleaguefrom officeand thus undermining the constitutional strength of the tribune's office upon which his own position depended. He carried his law and set up a commission to examine into the title deeds of property holders, to acquire the land to which the State had a legal right and to distribute it in allotments. To finance the settlement of his small-holders he then passed a bill in the Assembly, thereby infringing the recognised prerogative of the Senate to deal with all foreign affairs, that the treasure left to the Roman people by Attalus the last king of Pergamum, should be devoted to this purpose. Although it was technically illegal, it was necessary both for the carrying out of his scheme and for his personal safety that Gracchus should be re-el ected tribune for the foll owingyear, but theopposition was naturally bitter. Rioting took place, Gracchus was murdered, and by placing obstacles in the way of the already difficult task of the land commission the senate, without incurring the odium of its abolition, rendered its operations ineffective. ${ }^{34}$

In 123 Gaius Gracchus, theyounger brother of Tiberius, becametribune with the avowed object of carrying on his brother's work. The legal bar to the continuous tribunate had been removed and he was successful in holding the magistracy for two consecutive years, but at the elections for the third year he failed, and when his term of office came to an end he shared the fate of his brother and met his death as the victim of armed violence. There is no reason to doubt the sincerity and disinterestedness of Gaius' motives but his political methods, if more dexterous, were more disastrous than those of his brother. He secured his power by wholesale political bribery. The proletariat was bought by the provision that the State should supply the citizens of Rome with corn at less than the cost price. This dole constituted a serious drain upon the exchequer, it demoralised the recipients and set a disastrous precedent for the pol itical 
bribery of the urban rabble. Further it was prejudicial to the success of the Gracchan land scheme. It interested theState primarily in theimport of cheap foreign corn rather than in home production and it increased the attractions of urban life and thereby added to the difficulties of getting the poorer classes back to the land.

The support of the capitalist class was purchased by handing over the new province of Asia to the rapacity of the financial corporations which farmed the taxes, and by substituting capitalist for senatorial control of the courts which dealt with cases of extortion in the provinces. The I talian opposition to the surrender of publicland heattempted to remove by promises of thefranchise. Thus apart from the criticisms, which might be directed against these measures in themselves, two vital questions of the first importance, viz. thereform of judicial and provincial administration and the extension of the franchise to the Italians, were treated not upon their merits but as pawns in the game of Roman party politics.

Political bribery builds no secure foundations of power. The acceptance of undeserved benefits but whets the appetite for more, and popular gratitude has but a short memory. In political manoeuvre the opponents of Gracchus were a match for him. The purchased loyalty of the urban rabble proved a broken reed; skilful calumny and dexterous intriguewere successful in undermining his position with the ungrateful assembly, which was gulled by the sham generosity of the proposals put forward in the Senates' name by Livius Drusus in order to outbid Gracchus in popular favour. The rank and file of the popular party also bitterly resented the proposal that the citizenship, with perquisites which had now been increased by the corn dole, should be shared with I talians. His failure to secure re-election sealed the doom of Gaius Gracchus and within ten years the last traces of the Gracchan Iand legislation had been removed.

But there were deeper causes than the trend of party warfare which ensured the failure of the Gracchan scheme. Mr. Heitland has summed up the matter in a sentence. "E conomic reform, which in I taly of that period meant the revival of agriculture, was impossible without the abolition of slavery and the minds of men were far from ready to accept 


\section{W. R. Halliday, The Growth of the City State, 145}

so sweeping a change."135 The Gracchi wished to repopulate Italy with small peasant households whose little holdings would produce the necessities of their livelihood. But the small self-sufficient farm of this character belonged essentially to a more primitive and more simple type of society. The social conditions of which it was the natural product, and in which it flourished, had long ago passed away for better or for worse, nor could they be revived. Rome was no longer a homogeneous society of peasant farmers but a complex imperial state in which money-making was the chief driving force and individualistic capitalism ruled supreme. Regarded economically there could be no doubt that, wasteful though it might be owing to incompetent management, farming on a large scale was more profitablethan farming upon a small scale. Pasture runs in fact gave a better return upon outlay than corn-growing, as did those forms of agriculture, the growing of vines, fruit trees, etc., which demanded greater capital than the peasant possesses. As an economic rival it was impossible for the small man to compete with the capitalist whom the institution of slavery provided with abundant cheap labour. Nor was a precarious livelihood, earned by unremitting toil in themonotonous round of country life, a prospect which experience made attractive to men accustomed to the excitements of urban life with its games and shows and, thanks to Gaius Gracchus, its provision of cheap corn by the State.

In theyears which fol lowed the Gracchan attempt at reform, agriculture in Italy went from bad to worse. The terrible insecurity of life and property, which was an inevitable feature of a period of al most continuous civil war necessarily assisted its decline. Apart from the actual damage to the land, it is obvious that insecurity breeds a natural reluctance to make any improvements the fruit of which is not immediate. The growth of professional armies supplied a new career for the impoverished freeman, more congenial and a great deal morelucrative. At the end, too, of his mil itary career he could become a farmer, for it became the practice of successful army leaders to pay off their disbanded troops by confiscating land and settling them upon it. Nor did this policy improve the agricultural or political condition of I taly. The veterans made inefficient and discontented farmers while the persons who had been evicted for 
their benefit were added to the forces of disorder.

Theestablishment of the empire and the restoration of order put an end to some of these evils and property again became secure. All attempts however to repeople Italy with smallholders were unsuccessful. ${ }^{36}$ E conomic and social conditions were in fact overwhelmingly on the side of the large estate. Thehonest peasant, upon whose hardiness and si mple virtues the greatness of Rome had been built, continued to furnish a commonplace of rhetoric and literature, but it may be doubted whether the writers who sentimentalised on the subject had any real knowledge of peasants or genuine liking for country life, except as furnishing the occasional short holiday of the town-dweller.

Romae rus optas; absentem rusticus

Urbem Tollis ad astra levis."

It is not the least of Horace's attractions that he can laugh at himself.

Notes to Lecture VII.

1. Herodotus II, 167, Strabo VIII, 23, 382.

2. For Megarian trade in woollen cloaks see Xenophon, Memorabilia II, 7,6 , Aristophanes, Acharnians 519. For the salt trade see Acharnians 760, 814.

3. Aristotle, Politics IV , 6, 2, 1292b.

4. Euripides has described the autourgos, i.e, the small farmer, like the heroes of Aristophanes' plays, who no doubt employed slaves and hired labour on a small scale but himself worked on his farm. "Of rugged exterior, a manly man, little in touch with the city and the circle of the market, a man who works with his own hands - the kind upon whom alone the safety of the state depends - but shrewd, willing to come to an issue with thearguments, without guile, onewho had led a life without reproach." (Orestes, 917 foll.)

The virtues of the peasant farmer, whohad built up the fortunes of Rome, are a constant topic of Latin literature, eg., Horace, Odes, I, 12, III, 6, I uvenal, SatireXIV, 179 foll. Cato opens his treatise on agriculture 
W. R. Halliday, The Growth of the City State, 147

with a disquisition on the social, political and military virtues of farmers, though, as Heitland remarks, "his own scheme is not one for enabling a poor man to win a living for himself and family out of a little patch of ground. It is farming for profit" (Heitland, Agricola, p. 167). To this conventional sentiment Cicero made an eloquent if unscrupulous appeal in a celebrated trial. "In urbe luxuria creatur : ex luxuria existat auaritia, necesse est: ex auaritia erumpit audacia : inde omnia scelera. Vita autem haec rustica, quam tu agrestem vocas, parsimoniae, diligentiae, iustitiae magistra est " (Pro Roscio Amerino, 27).

5. "They are the ruin of the bodies of all concerned in them, workers and overseers alike, who are forced to remain in sitting postures and to hug gloom or else to crouch whole days confronting a furnace. Hand in hand with physical enervation follows apace enfeeblement of soul" (Xenophon, Oeconomicus IV , 2). Agriculture on the other hand "is at once the easiest employment to learn and the pleasantest to pursue, since it gives to the limbs strength and hardihood, whilst permitting to the soul leisure to satisfy the claims of friendship and of civic duty" (ib., VI, 9).

6. "Well we shall not be ashamed, I hope, to imitate the king of Persia ? That monarch, it is said, regards among the noblest and most necessary pursuits two in particular, which are the arts of husbandry and war, and in these two hetakes the strongest interest" (Xenophon, Oeconomicus IV , 4). The superior military qualities of a peasantry as opposed to an artisan population are discussed further VI, 6- 7. Cf. Varro, de Re Rustica III, 1,4, "And not only is farming more ancient, it is also better; wherefore our ancestors with good reason sent their citizens from the town back to the land, for in peace they were fed by the rustic Romans and in war were defended by them."

7. "And indeed for the first time in my lifetime the Athenians seem to have enjoyed a good constitution. For therewas a blending fair to both parties of the few and the many and this, after affairs had become disastrous, first enabled the city to raise her head" (Thucydides VIII, $97,2)$. Thus echoes of the moderate programme may be detected in 
W. R. Halliday, The Growth of the City State, 148

Plato's Laws, e.g., III , 698 "back to the constitution of our fathers", or $\mathrm{VI}, 753$, the desirability of restricting the franchise to the hoplite census.

8. Aristotle, Politics VI, 4, I, 1318b.

9. Aristotle, Politics IV , 6, 2, 1292b; Xenophon Oeconomicus VI, 10, "For which reason also this way of life stood in the highest repute in the eyes of statesmen and commonwealth as furnishing the best citizens and those best disposed to the common weal."

10. Verumque confitentibus Iatifundia perdidere Italiam, iam uero et provincias. Sex domini semissem Africae possidebant, cum interfecit eos Nero princeps" (Pliny, Nat. Hist., XVIII , 35). Pliny's generalisation is open to criticism as a rhetorical exaggeration, but though we must not suppose that all the land of I taly was in the hands of two or three individuals, it is true that capital ist farming had entirely ousted the peasant proprietor. Cato's fundus is not a latifundium but it is a commercial concern demanding considerable capital, labour, and plant, entirely different from the self-supporting peasant holdings, which the Gracchi wanted to re-introduce.

11. Thus there were land distributions in 456 (Aventine), 418 (Labici), 394 (Veientine land), 383 (Pomptine land). Between 442 and 383 five Latin colonies were planted. These like the Periclean cleruchies, which are the nearest analogies in Greek history, provided economic rel ief to the poorer classes as well as political and military strength to theState. Between 416 and 410 therewerefrequent land bills brought forward but were blocked. Therich and poor plebeians were not at the moment working together and agrarian concession, which was al ways reluctantly granted, was therefore not a political necessity.

12. See above p. 43 note 13.

13. See Gwynn, "The Character of Greek Colonisation," J ournal of Hellenic Studies, XXXVIII, pp. 85 foll.

14. The Greeks of course were fully al ive to the dependence of the farmer upon seasons which he cannot control. "Otherwise at other times is the will of Zeus, the Lord of the Aegis, and hard for mortal men to know" (Hesiod, Works and Days, 483). Cf. Xenophon, Oeconomicus V, 
18 , whose solution for the farmer's difficulty is the practice of piety. In an interesting passage Mr. Heitland points out that this characteristic of farming, which distinguishes it from other forms of industry, is of no little importance to the modern problem of the position of Labour. "Is a political proletariate competent to regulate the conduct of an industry directly dependent on soil, climate and seasons ? Wherever man is in immediate contact with forces of nature, in farm life as in seafaring, the bodily energies of many can only be effective through subordination to the mind of one. How far, under the modern factory system, where the mill goes on as usual in all weathers, direction by wage-earners may be a practicable proposition, I cannot tell. That such a plan would be a failure on a farm, I have no doubt whatever" (Heitland, Agricola, p. 458).

15. Both large and small estates in Greece and I taly in the era before the birth of Christ were normally farmed by the proprietor or by slave labour directly upon his behalf. In the early communities of Greece and Romesmall holdings were the rule, and they were worked by the proprietor and his household, i.e. his sons and his slaves, the Roman familia. The large land owner who ousted the peasant proprietor did not al ways personally superintend the work upon his farm, but it was performed upon his behalf by slaves, who werehis property, under the superintendence of a slave overseer, and all the profits were supposed to go into his pocket. Tenant farming existed sporadically in I taly in the first century B.C. but the practice of letting parts of a big estate to tenants in return for their services seems to have devel oped considerable proportions only after the Roman E mpire had established peace in the Mediterranean area and slave labour consequently became more difficult to procure. These col oni, as they were called, gradually became the tenant serfs of the later Roman Empire who were tied to the soil which they tilled. Upon the whole subject see Heitland, Agricola.

16. Small intensive farming needs capital, plant, and a near market. Almost invariably the best profit is obtained by growing or breeding only the very best of their kind, eg. pedigree fowls. This again 
demands capital outlay. A good example is the bee farm of one iugerum (Varro III , 16, 10). "It seems to have been a very exceptional case and to be cited as such; it is very different from that of the peasant farmer of early Rome concerned first of all to grow food for himself and his family" (Heitland, Agricola, p. 184).

17. See p. 105, note 28.

18. Aristotle, Politics II, 7. 6. 1266b.

19. "Observing that the city was filled with men who came from all countries to take refuge in Attica, that the country was for the most part poor and unproductive and that merchants also are unwilling to despatch cargoes to a country which has nothing to export, he encouraged his countrymen to embark in trade and made a law that a son was not obliged to support his father if his father had not taught him a trade " (Plutarch, Sol on XXII).

20. Androtion is quoted in Plutarch's Life of Solon as the ancient champion of the view that the reform consisted of a debasing of the currency. Androtion gives the proportion of the two standards as 100 : 73; Aristotle as $100: 70$. Prof. P. Gardner points out that the first is roughly the proportion of the Aeginetan to the Attic standard, the second that of the Aeginetan to the Euboic. "It is very natural that Plutarch's authority writing at a time when the Attic standard was in universal use, should have supposed that it was that which was introduced by Solon, But we have in Aristotle a valuable record of the real facts of the case: if we may believe him, it was not the later Attic standard which Solon introduced but the real Euboic, which was appreciably lighter." This seems to be against the 'debasing of courrency' theory, for the change links Athens to the standard 'which was al ready accepted at Chalkis and Eretria and (with a different system of division) at Corinth" (P. Gardner, History of Ancient Coinage B.C. 7000-300, pp. 143-153). Corinth was of course at this time friendly to Athens. See p. 45, note 18.

21. Aristotle, Constitution of Athens, 16.

22. The tax was ten per cent, according to Aristotle, Const. Ath. 16; five per cent, according to Thucydides VI, 54. For the local justices see 
W. R. Halliday, The Growth of the City State, 151

Aristotle, Const. Ath., 16, 26, 53. Thirty were appointed by Peisistratus. After the fall of the tyranny they ceased to exist but were reinstituted in 453 B.C. At the beginning of the fourth century their numbers were increased to forty. They possessed full powers to decide petty cases up to 10 drachmae.

23. Cf. thestory in Livy of theex-centurion covered with honourablescars who had been ruined during the Sabine Wars. His land had been devastated by the enemy, he had to borrow money to meet taxation, his creditors had stripped him of all his remaining property and then flung him into gaol (Livy II, 23).

24. Like Germany Sparta attempted to use the weapon of the weaker naval power, a ruthless war upon sea-borne commerce. "The Lacedaemonians killed as enemies all whom they took at sea, whether confederates of the Athenians or neutral" (Thucydides II, 67, 4). Inevitably the policy led to diplomatic difficulties with neutrals in ancient as in modern times (Thucydides III, 32).

25. The land had suffered comparatively little in the Archidamian War, merely destruction of the standing crops, but when Deceleia was occupied Attica was systematically stripped. A fourth century historian tells us that the Thebans madea large profit from buying up slaves and gear from occupied Attica. Even the timber and tiles from the buildings were stripped and found a market in Boeotia (Hellenica Oxyrhyncia. XII, 4-5).

26. See the later plays of Aristophanes eg., Plutus 223. Chremylus:

"Summon my farm companions from the fields (You'll find them there, poor fellows, hard at work) And fetch them hither : so that each and all May have, with me, an equal share in Wealth." In the same play Cario asks the Informer "Are you a farmer?" "Do you think I am as melancholy mad as that?" is the reply (Plutus 903).

27. See Xenophon, Oeconomi cus XX, 22. The reason that there was badly farmed land cheap on the market was partly the rural exodus characteristic of the time and partly the result of the damage caused to agriculture by the Peloponnesian War. The big estate thus formed was worked by slaves under slave overseers (Xenophon, Oeconomicus 
W. R. Halliday, The Growth of the City State, 152

XII, 3). For the attractions of land as an investment in the fourth century see Heitland, Agricola, p. 106 and the references there given. "The type of farmer known to us from Aristophanes, who works a holding of moderate size, a man not wealthy but comfortable, a wellto-do peasant proprietor who lives among the slaves whose labour he directs, is hardly referred to directly in the speeches of this period" (that of Demosthenes and his contemporaries). (Heitland, Agricola, p. 107.)

28. "The free farmers had perished in the war, there was a shortage of slaves, thelive stock had been carried off and the farmsteads wrecked or burned" (Livy XXVIII, II, 9).

29. Cheap land and cheap labour ruthlessly expl oited made landed estate upon a large scale a profitable form of investment. The possession of land had also a social and therefore political value and further, according to law, it was the only form of investment open to senators. It is true however that the law was evaded. Senators invested capital in commerce or lent it out at exorbitant interest in the name of an agent. The elder Cato is an example of the former (Plutarch, Cato Maior, 21); Brutus, whose extortions through an agent call ed Scaptius caused embarrassment to Cicero when governor of Cilicia, is an example of the latter (Cicero, ad Att. V, 21, VI , 2. translation in J eans, Life and Letters of Cicero - Watson, Cicero, Select Letters, Nos. 36, 38).

30. The slave shepherds on the big sheep runs were naturally armed in order to be able to protect their flocks against wild beasts or thieves. It was inevitable that they should practise brigandage. Their owners might and did employ them as an armed force either in civil war or as an influence in politics in which during the last century of the Republic force not argument became the arbiter. Both I taly and the provinces suffered from frequent slave risings which often assumed the proportions of serious wars eg. in 196 (Etruria), 185 (Apulia), 139 (Sicily), 135- 131 (Sicily), 132-130 (Asia), 103-99 (Sicily). F rom 73-71 Spartacus with his army of slaves and gladiators defied the armies of the Roman state in I taly. 
W. R. Halliday, The Growth of the City State, 153

31. According to Appian alarm at the decline of the birthrate was one of the chief motives of Tiberius Gracchus. The census lists for the half century before 131 show a steady decline in the citizen population. In Livy's own times, i.e reign of Augustus, the land of the Volscians and Aequians, so populous in early Roman history, was almost uninhabited except by slave gangs (Livy VI, 12); "so true is it that we have improved in those particulars only about which we are solicitous, riches and luxury" (ib. VII, 25).

32. Plutarch, Tiberius Gracchus, 9. The source is the Memoirs of Gaius Gracchus and no doubt the fragment of Tiberius' speech is authentic.

33. See Heitland, Agricola, p. 153 foll.

34. The method of blocking the work of the land commission was simple but effective. The judicial powers of the commission were transferred to the consul Tuditanus, who then left Italy to take up a foreign command. The commission retained the power of making the allotments but having lost the power of adjudicating upon claims to ownership, they had no land to allot. The consul possessed the necessary power of adjudication but then he was no longer in I taly to exercise it.

35. Heitland, Roman Republic II, p. 323.

36. Augustus restored order in the countryside and put down the brigands who kidnapped travellers indiscriminately and sold them into slavery in the ergastula, the great slave barracks of the Roman plantation system (Suetonius, Augustus 32). For a full discussion of the literary propaganda of agricultural reform and its significance in fact see Heitland, Agricola cap. XXIX.

37. Horace, Satirell, 7, 28. 
Lecture VIII. Pheidippides. Social Conditions in Athens in the Fifth Century.

In aristocratic fashion as in other things the latter half of the fifth century B.C. was a time of transition. In the period of the Persian wars, the I onic luxury of Peisistratean Athens had been succeeded by a reaction towards simplicity; ${ }^{1}$ the Ionic linen tunic and the golden grasshopper comb had gone out of fashion. ${ }^{2}$ Thetendency was antagonisticto anything smacking of Oriental effeminacy, and the conquer ors of theM edeadopted the style of the leading military state among the patriot Greeks. The Athenian man of fashion wore his hair long and curled ${ }^{3}$ in imitation of the heroes of Thermopylae, ${ }^{4}$ red Laconian shoes were on his feet, ${ }^{5}$ and he carried in his hand a walking stick of the true Laconian curve. ${ }^{6} \mathrm{His}$ political sympathies were with the champions of conservatism, and alike the character and stability of the Spartan constitution aroused his admiration. The athletic and military prowess of the Spartiate appealed to him; boxing became a fashionable amusement, and broken ears an honourable distinction. ${ }^{7}$ Most things the Athenian aristocrat considered were not only differently but better managed in Lacedaemon than by the upstart sailor democracy at home. ${ }^{8}$

Megacles, the son of Megacles, one imagines to have been of this school. ${ }^{9}$ When Thucydides, son of Melesias was hounded out of public life by the new generation, he despaired of politics. ${ }^{10}$ It gave him no pleasure, he would say, to rub shoulders with the great unwashed in the Assembly. ${ }^{11}$ Publiclifewas nolonger fit for a gentl eman. That fell ow Pericles, his own relation too, had started the systematic bribery of the rabble. They might boast of their progress, of their harbours, docks, and the like, but where was it going to end? As far as he could see, progress had eliminated honesty, ${ }^{12}$ made the people slaves of a largess or bribe, ${ }^{13}$ and created a race of corrupt and usel ess sycophants, minding everybody's business but their own. ${ }^{14}$ There is no living nowadays in Athens for the informers. ${ }^{15}$ 


\section{W. R. Halliday, The Growth of the City State, 155}

And look at the kind of man, which payment for political duties is bringing into public life. In the place of Aristeides, Themistocles and Miltiades you have Lysicrates, Cleon and Hyperbol us. ${ }^{16}$ To be a gentleman or to have had a liberal education was nowadays a positive bar to a political career. ${ }^{17}$ I $\mathrm{n}$ fact to come to the front you had to be some sort of huckster or other. ${ }^{18}$ The whole tone of public life had been lowered. You could see it in the way these political adventurers bawl and gesticulate instead of making a speech. ${ }^{19}$ And the eloquence of the statesman has disappeared in thetorrent of slang phrases, catchpenny metaphors of the market place and oracular rubbish with which this tanner fellow overwhelms his audience. ${ }^{20}$ They were always urging expeditions to Carthage and God knows where; it would be a service to the state to put them on their saletrays and launch them out to sea to voyage to the kites and crows. ${ }^{21}$

In such terms we may imagine Megacles holding forth at the club over a game of dice or draughts. His political animus was no doubt embittered by the increasing demands on his purse. Democratic finance seemed to be based upon the blackmail and spoliation of the rich, and it but added insult to injury that the bulk of the spoils went into the pockets of the politicians rather than tothebenefit of their dupes. ${ }^{22}$ Therewas nojustice for a gentl eman in the courts when juries werereminded that convictions were necessary in order to finance the payment of their salaries. ${ }^{23}$ What with liturgies and property taxes the demagogues seemed to think that they could bleed the gentlemen to any extent. ${ }^{24}$ And living had become very expensive for a Megacles, who was too great a gentleman to improve his fortune by work. ${ }^{26}$ The town house with its marble pillars ${ }^{26}$ and frescoed hall ${ }^{27}$ had to be kept up. An Alcmaeonid had a position to maintain, and he felt it his duty to do a certain amount of entertaining, both private and public. ${ }^{28} \mathrm{~N}$ or did the democrats seem to real ise that a gentleman who kept up a certain style was doing a public service and benefiting the city as a whole. ${ }^{29}$ The world was topsy-turvey, and every $J$ ack, nowadays thought himself a good deal better than his master. Even the slaves give themselves the airs of Athenian citizens. ${ }^{30}$ And the price of slaves was preposterous. At the last New Moon Fair ${ }^{31}$ he had had to 
pay over $300 \mathrm{dr}$. for a Syrian. ${ }^{32}$ But a man in his position could hardly walk down Odeum Street with fewer than three attendants. ${ }^{33}$ By Poseidon, he would give something to be in the capacious shoes of the founder of his family, ${ }^{34}$ or have half the money that had been thrown away on that façade at Delphi. ${ }^{35} \mathrm{His}$ stud cost him a pretty penny, too, but after all one must have a pair of Corinthian thoroughbreds. ${ }^{36} \mathrm{Hehad}$ been amused the other day at the barber's. ${ }^{37}$ While Sporgilus ${ }^{38}$ was manicuring him, ${ }^{39}$ a dirty monkey-faced fellow, wholooked as though you could have bought him up lock, stock and barrel for five minae, had come in and started arguing that he was the richest man in the shop, because he had no expenses. ${ }^{40} \mathrm{~A}$ shrewd fellow that; most of the rabble didn't seem to realise what it cost a gentleman to live nowadays.

It will be observed that Laconian simplicity of fashion had been somewhat tempered to the needs of a society enriched by Persian booty and the spoils of empire. A Spartan would hardly have recognised its habit as his, and, if the clothes remained Laconian in cut, their material was of purple and fine linen. ${ }^{41}$ Laconism was, in fact, an affectation to which none but the philosophers paid more than lip service. ${ }^{42}$

The growth of luxury was inevitable. The Piraeus had become the central mart for the civilised world. ${ }^{43}$ To it flowed the commodities of all countries, and even those most valuable of rarities only to be found on the fringes of the known world. ${ }^{44}$ To Athens, as to the court of Solomon, the ships brought home their peacocks, apes and ivories. ${ }^{45}$

But the devel opment of commerce had had a further result. During the Fifty Years the balance of wealth in the community was changing hands. It was passing from the old aristocracy to the skilful investor like Nicias, in turn to pass from him in the fourth century to the slave or freedman banker like Pasion. Relatively, the class to which Megacles bel onged was becoming poor, while at the same time family pride forbade a reduction in their style of living.

Megacles may well have been short of ready money, and was no doubt anxious to get his niece off his hands. She had turned fifteen ${ }^{46}$ and it was high time that she was married. Old What-is-her-name, the matchmaker ${ }^{47}$ had brought an offer from Strepsiades. The fellow was a 


\section{W. R. Halliday, The Growth of the City State, 157}

bit of a boor, of course, with his big hob-nailed boots, ${ }^{48}$ but he had a nice little property at Kikynna, ${ }^{49}$ and his father, who was notoriously close, ${ }^{50}$ must have left him pretty well off. And probably he would not press the matter of dowry in a match socially so advantageous. The girl might do a great deal worse.

The girl herself was delighted at the prospect of marriage. She was tired of being told that little girls should not see nor hear anything nor ask questions $^{51}$ and of listening to her aunt's lectures upon modest behaviour. ${ }^{52}$ Her husband sounded rather countrified, but she had been told that every girl should pray "for a wealthy husband, and a fool to boot. ${ }^{153} \mathrm{H}$ e seemed to be pretty well off and she would be able to wheedle him. What lovely saffron robes, transparent Cimmerian vests and embroidered dresses she would buy. ${ }^{54}$ She would have nothing but the finest Milesian wool and Amorgos linen in her house. ${ }^{55}$

And so on the lucky fourth ${ }^{56}$ of the fashionable month ${ }^{57}$ they were married, the bride radiant in a lovely wedding dress. ${ }^{58}$ But Strepsiades soon becamealarmed at his wife's extravagance. She was al ways wasting money upon scents and sweets. ${ }^{59} \mathrm{He} \mathrm{had} \mathrm{tried} \mathrm{in} \mathrm{vain} \mathrm{to} \mathrm{laugh} \mathrm{her} \mathrm{out} \mathrm{of}$ the use of powder, rouge and high-heeled shoes. ${ }^{60}$ But worse than her extravagance was her waste. She could spin and cook, and was not idle, but she was a thoroughly bad housekeeper, with no idea of method or order, and the money seemed to melt away in a fashion calculated to make old Pheidon turn in his grave. ${ }^{61} \mathrm{He}$ had been driven at last to taking the store-room out of her hands and locking it up. ${ }^{62}$ There had been a scene about that - she had even tried to hit him with a slipper. ${ }^{63}$ In fact, al though it never became a scandal, like the quarrels of Panaetius, the cutler, with his wife, ${ }^{64}$ their married life was stormy. Nor can it be denied that the wife had some grounds for complaint. She was bored with her husband's endless talk of ol ives, sheepfolds and honeybees. ${ }^{65} \mathrm{He}$ was so slovenly in his dress, too, and she did object to the smell of the farmyard being brought into the bedroom. ${ }^{66}$

The birth of a son and heir, however, drew them together.

Oh, what delight, surprise, congratulations! Theman runs in; thenurse comes running out. "A prodigy! A lion! Such a boy! Your very image; 
W. R. Halliday, The Growth of the City State, 158

lucky, lucky man!"167

But the question of a name revived dissension. They were agreed that foreign names might beleft to the sons of tyrants or diplomatists. ${ }^{68}$ It was not a period of Athenian victories, so that there was little temptation to name him after an historical event. ${ }^{69}$ Strepsiades favoured the good oldfashi oned practice of call ing the el dest son after his grandfather, ${ }^{70}$ but his mother wanted something more aristocratic - after all she was an Alcmaeonid!

She was for giving him some knightly name-Callippides, Xanthippus or Charippus.

Comparative harmony was restored by the compromise, Phei dippi des. ${ }^{71}$ The tenth day feast went off splendidly. ${ }^{72} \mathrm{~N}$ or did the baby cry when Uncle Megacles magnificently presented him with an Archytas rattle. ${ }^{73}$ In fact, the only thing that at all marred the success of the entertainment was the misfortune of a guest from the country who got sandbagged by a foot-pad on his way home. He had had a drop too much and went off in the dark without a link boy. After stumbling through the mud and stones of the streets, he had just got outside the city walls, when Orestes, or one of that gang, knocked him down from behind and stripped him of his cloak of Phrygian wool. ${ }^{74}$

The baby looked a dear little fellow in his Cretan shortening clothes, with little yellow Persian slippers like his mother's, ${ }^{75}$ and Strepsiades was a doting father. ${ }^{76} \mathrm{He}$ was al ways fussing round it, and enraged the Spartan nurse ${ }^{77}$ by declaring that she did not feed the child properly. He would snatch him from her and feed him from his own mouth, chirping endearments and call ing him "Papa's little rascal. ${ }^{.78}$ When hegrew older, he would play horses with him and career around astride a walkingstick. ${ }^{79}$ He taught him to wrestle and to run, but was very careful not to let him get overtired. ${ }^{80}$ On wet days, when the sun refused to respond to the nursery song, "Come out dear Sun," ${ }^{11}$ they had great games indoors. The youngster was as sharp as anything and learned

To build small baby-houses, boats. Go-carts of leather, darling little frogs Carved from pomegranates, you can't think how nicely. ${ }^{84}$

Then, there was the great game of law courts. Sometimes Papa and 
Xanthias, the slave, would help, and the former would allow the boy to take the railing from the pig-pen in thestables, just inside the front door, to make a proper court. Often, of course, he had to play by himself with Pincher, the house-dog, and the kitchen utensils to fill the roles. Pincher was usually the prisoner, and the boy was quite ready to take all the speaking parts from that of the presiding officer to the accused. ${ }^{83}$

On his way home from the real courts, Strepsiades would often buy figs, and the boy would have a happy evening bobbing for them. ${ }^{84} \mathrm{H}$ is first fee as a juryman his father spent at the Diasia fair upon a little toy cart. ${ }^{85} \mathrm{It}$ only cost one obol, but the boy was delighted. Even better though, he loved his jackdaw, for which Strepsiades paid the same price at Philocrates' stall in the bird market. They had great fun with it for they got a little brass shield, and made a little ladder, and taught the bird to play tricks, hopping up and down the ladder with the shield. ${ }^{86}$

Flatterers won an easy way into Strepsiades' favour by singing the praises of his son who put up heroically with their kisses, and the monotony of being told that he was a "chick of a good father," for the sake of the presents of knucklebones, figs, apples and pears which they brought him. ${ }^{87}$ At a dinner party, his father would send for him from the women's quarters, and have him sit on his couch and would listen complacently while the guests enlarged upon the likeness of father and son. The unfortunate guests were bored by having to play Wineskin and Hatchet with him, or having the tired urchin fall asleep on top of them. ${ }^{88}$ When there was no company Strepsiades would talk him to sleep ${ }^{89}$ with stories of the country, picturing the time

When the goats you are driving from the fells Clad like your father in your sheepskin coat. ${ }^{80}$

The boy preferred thesestories toZeus, theE agle, and the Dungbeetle, ${ }^{91}$ once upon a time there were a cat and a mouse ${ }^{92}$ Atalanta ${ }^{93}$ and the other items in his nurse's repertoire ${ }^{94}$ but Papa's vein of rustic reminiscence became a little monotonous. From his earliest years the boy had loved horses and fine clothes. Even as a baby his mother would soothe his crying with "Don't cry, and mummy will buy you a Bucephalus," him with promises of how, when he was grown up, he would drive to the 
W. R. Halliday, The Growth of the City State, 160

Acropol is in the Panathenaic procession, like Uncle Megacles, dressed in a wonderful purple cloak, and behind a pair of iron grey Corinthian thoroughbreds. ${ }^{96} \mathrm{His}$ aristocratic uncle took a kindly interest in the boy, and when he was seven years old he urged his father to send him to school..$^{97} \mathrm{He}$ was getting spoiled at home, and it was high time that he was packed off. The great thing was to make a gentleman of him. Of course, he must learn his three R's, and be able to quote Homer. ${ }^{98}$ Y ou don't want him to be as ignorant as a sausage seller. ${ }^{99}$ But on the other hand, manners are the great thing, and character matters more than playing the harp. ${ }^{100}$ You don't want him to turn out a narrow-chested, pale-faced intellectual with the authentic Attic look. ${ }^{101}$ It is most important to choosea good old-fashioned school wherethelads get taught to respect their elders, ${ }^{102}$ and there is none of this modern nonsense of coddl ing the boys up. ${ }^{103} \mathrm{I}$ t is ludicrous to seethese little fellows nowadays, wrapped up to the eyes in cloaks, when you think of how we used to walk down to school, all the boys of the parish together, singing a good old tune - none of this modern ragtime - and whatever the weather, snow or sleet, none had more than a tunic on. ${ }^{104} \mathrm{~A}$ boy needs hardening. And none of your new-fangled hot baths, sir. ${ }^{105}$ They are the ruin of the boys. It makes them soft, and they get into all sorts of mischief hanging about the baths after school hours. ${ }^{106}$ Choose a school where the discipline is good. Don't send him to one of these palaestras where parents and others are al ways dropping in. Solon knew what he was about when he made the law that nobody except a son, brother, or son-in-law of the master should be all owed to enter school or palaestra in school hours. ${ }^{107}$ It is the ruin of discipline. The parents get chattering to the master and the boys and nothing gets done, ${ }^{108}$ and there are some nasty stories going about about the moral tone of some of these places. The boys pick up all sorts of effeminatetricks, messing themselves about with unguents and goodness knows what. ${ }^{109}$

The advice of Megacles was taken - and a school was chosen, a better class seminary than that in which theyoung Aeschines mixed theink and swabbed the benches. ${ }^{110}$ Every morning before daybreak ${ }^{111}$ Pheidippides would set out in charge of an elderly slave who carried his books and 


\section{W. R. Halliday, The Growth of the City State, 161}

writing materials. This pedagogue was a foreigner, but he had been carefully sel ected. He was sensi ble and strict, and spoke excellent Greek, except when he had had a drop too much. ${ }^{112}$ He kept the boy in order, and brought him back when the school closed at sunset. When he started going to school, his father gave Pheidippides a little tawny coloured Melitean dog for his very own. ${ }^{113}$ The boy carried it in the fold of his cloak and it went with him everywhere, lying behind him while he was doing his lessons. ${ }^{114}$

These, at first, were not heavy. In the palaestra he spent most of his time watching the older boys, though there was a certain amount of simple physical exercises through which, in company with the rest of the infant class, he was put. In school he learned the al phabet, and then to write the letters between the lines ruled for him by the master on his wax tablet. Later on helearned to count, first on his fingers, and then with the counting board, and to grapple with simple sums. Then, of course, there was the music lesson, and the literature class where he learned something of the poems of Homer and Hesiod. His training on the physical side was similarly progessive, and when he passed out of the infant class he learned wrestling, running, boxing, and the other manly accomplishments. ${ }^{115}$

Pheidippides was a sturdy boy ${ }^{116}$ and thoroughly enjoyed these athletic exercises, and his favourite way of spending a hol iday was to go down to the Academy, the great recreation ground, laid out originally by Cimon, about three quarters of a mile beyond the city walls, and spend a happy day running races with his special chum. ${ }^{117}$

All fragrant with woodbineand peaceful content, and the leaf which the lime blossoms fling When the plane whispers loveto the el $m$ in the grove in the beautiful season of spring. ${ }^{118}$

The Athenian small boy was very like other small boys, and learned much the same lessons from contact with his fellows. Pheidippides soon learned that juniors must be seen and not heard, ${ }^{119}$ and may on no account help themselves before their seniors at table. ${ }^{120} \mathrm{He}$ was taught to sit in class with his knees together and tucked up decently under his chiton, ${ }^{121}$ to rise and give up his seat to his elders, ${ }^{122}$ and not to giggle or 


\section{W. R. Halliday, The Growth of the City State, 162}

cross his legs at table. Eating tuck was also forbidden, ${ }^{123}$ but one may doubt if the law was honoured by small boys in the observance.

When he went home he would retail, after the manner of small boys the gossip of the school, and Strepsiades soon got to know the nicknames of the boys, and all about those mammysucks, the sons of Hippocrates. Nasty little beasts ! We call them the swine. ${ }^{124}$ They are no good at anything except swotting. They arehopel ess to have on the si de at "Night and Day, ${ }^{125}$ and they areal ways the first to be made donkey when we are playing ball. ${ }^{126}$ Of course, the master is keen on them. He gave one of the little beasts a basket of knucklebones the other day as a prize for writing. ${ }^{127}$ We soon won them off him though at odd and even. ${ }^{128}$ Their people live in a lodging house, too. ${ }^{129}$ There is no snob like your school boy!

There were two fellows whose father was so mean that he didn't send them to school at all in Anthesterion, because there were so many holidays in the month that he was not getting his money's worth. ${ }^{130}$ Pretty good business for the boys that, but they lost on the feasts of Hermes and the Muses, for then their father put them to bed and pretended that they were ill, in order to avoid sending a contribution to the sacrifice and a present to the master. ${ }^{131}$

Stories, too, were brought home of the escapades of the school heroes. There was a fellow who called out "Look at the swallow" as he passed the cook's shop, and while they were looking up, snapped up a piece of meat. ${ }^{132}$ The same chap had to divide a drachma with a shortsighted fellow. He put down some fishscales and the shortsighted chap put them into his mouth, thinking that they were coins! $!^{133}$ They had a great plan, too, one day of tying a light onto one of the cockchafers they had on a string, and setting the master's house on fire. ${ }^{134}$ It didn't work, but it was a jolly good idea. And then there was that ass Euel pides. His father gave him a tip the other day, and he was going down to the bazaar when he saw the first kite of the year. He prostrated himself to salute it, and in doing so swallowed the coin! $!^{135}$

Strepsiades would listen to all this school gossip, and, like other fathers, would try to show an intelligent interest in his son's lessons, examining 


\section{W. R. Halliday, The Growth of the City State, 163}

him about themeaning of thelong words in Homer. Pheidippides retorted with embarrassing conundrums about Solon's laws, and, like other fathers after him, Strepsiades would sometimes find himself out of his depth. ${ }^{136}$

In the holidays the father would take his son to see the conjuror, ${ }^{137}$ or they would spend a day in the gardens of Pyrilampes looking at the peacocks which hehad brought home from Persia when he was ambassador. ${ }^{138}$ At the Lenaea and Dionysia they would go to the theatre. ${ }^{139}$ And then there were the school festivals - those of the Muses in the schools and of Hermes in the palaestra. ${ }^{140} \mathrm{H}$ is mother would take out the boy's best white clothes ${ }^{141}$ from the chest where they were carefully put away with citrons to make them fragrant and to keep out the moth, ${ }^{142}$ and off Pheidipiddes would trot with the pedagogue behind him carrying a contribution to the sacrifice, and perhaps a sack of flour as a present to the master or paidotribes. ${ }^{143}$ All the boys, big and little would be assembled ${ }^{144}$ and there would be a lot of grown ups present, and feasting and a good deal of playing of knucklebones and odd and even. ${ }^{146}$ And as they went homeat sunset the pedagogue would bea little unsteady on his legs. ${ }^{146}$

In fact, Phei dippi des had a pretty good time, and if he was kept in order at school, there is little doubt that he was spoiled at home. Once or twice he received the thrashing which he deserved. He got caught once playing with his mother's spinning instruments, ${ }^{147}$ and then there was the time when he took advantage of the slave's back being turned to jump into the mule cart and drive off in it. ${ }^{148}$ But his father beat him with rel uctance, ${ }^{149}$ and as he grew older his hold over him became weaker and weaker. He was more than half afraid of him totell thetruth. ${ }^{150} \mathrm{~F}$ or Pheidippides had now become a school blood to whom the little boys looked up with awe, ${ }^{151}$ and was inclined to treat his family cavalierly. When spoken to by his father he would sometimes answer back, or go off grumbling audibly to himself about musty old J aphets and antediluvian notions. ${ }^{152}$

When Pheidi pi ddes was sixteen, and the time had come for him to leave school, the problem of what was to be done with him arose. It was a problem familiar to the Athenian parent of the upper class, for the 
educational system in Athens was not organised, and the gap between school and military service presented real difficulties to the parent.

Pheidipiddes, at the end of his schooling, had developed a taste for luxury, and had learned to look down upon agricultural labour. Like the father in the "Banqueters," Strepsiades complained that his boy had not learned any of the things he was sent to school to learn, but only to drink, to sing rather badly, and to appreciate Syracusan cooking, Sybaritic feasts and Chian wine out of Laconian cups. ${ }^{153} \mathrm{And} P$ heidippides declared that he was not going to break his back digging in the fields at Kikynna. ${ }^{154}$

Probably the lad got support from Megacles. We know that at a later date, when Strepsiades insisted upon his going to Socrates' lectures, that hethreatens to appeal to his uncle, who he is confident will not leave him horseless. ${ }^{155}$ The Megacles type takes a generous view of youth's wild oats. His father, as we have noticed, was more than half afraid of his aristocratic son, and so Pheidippides ran wild with the knights.

Our hero has been compared to Thrasymachus in the "Banqueters," but to give him his due he was not like Thrasymachus, a dilletante aesthete, who found even playing the flute or lyre an awful fag. ${ }^{156} \mathrm{~N}$ or, as a whole, were the Athenian knights decadents like the young aristocracy, which Sybaris is said to have bred. ${ }^{157}$ There were, of course, exceptions. There were the young men who lounged about the perfume market using exquisite adjectives ending in $\{\tau \kappa \kappa s\}$, and spending their day in the discussion of causes celebres, when in the opinion of Aristophanes they would have been better empl oyed in the hunting field. ${ }^{158}$ Parallels will be familiar among Oxford and Cambridge undergraduates, but in ancient, as in modern times they do not represent thetype. Effeminateindividuals like the fat glutton and coward Cleonymus, ${ }^{159}$ or the smooth-cheeked Cleisthenes ${ }^{160}$ are definitely under the ban of public opinion. And though the morals of youthful aristocracy were no more straitlaced at Athens than elsewhere, there was evidently a definite code, to offend which put a man beyond the pale. Ingenious experts in vicelike Ariphrades are put in Coventry, ${ }^{161}$ while an Aristyllus, who, one may suspect, did not show petty ambition in the matter of cleaning his teeth, has his nose rubbed in 


\section{W. R. Halliday, The Growth of the City State, 165}

the mud for it. ${ }^{162}$ Until Alcibiades set the new fashion, their attitude towards the intel lectuals was contemptuous, and they looked down from the twin heights of athleticand aristocratic prejudice upon the unwashed terrae filii who went about clad in rags with countenances paled by study. ${ }^{163}$ And, if in times of peace, they were extravagant, reckless and affected, when war came they rose to the occasion. There were, no doubt, a few hangers-on like Amynias, ${ }^{164}$ shirkers of military service, whose courage was limited to the gambling den, but, as a class they responded to their country's call.

Our ambition is to fight F reely for our gods and country, as our fathers fought before No reward or pay receiving, asking this and nothing more. When returning Peace shall set us free from all our warlike toil, Grudge us not our flowing ringlets, grudge us not our baths and oil. ${ }^{166}$

These were the associates of Pheidippides, and from them he learned the canons of good form. I t was the thing to wear the hair in long ringl ets, golden ringlets being especially admired. ${ }^{166}$ Some, like the young Cratinus, affected the topknot, the hair at either side of it being shaved off with a razor ${ }^{167}$ This mode, however, was a little extreme. In clothes, bright colours were the fashion, and the exquisites wore the himation long, trailing to their heels. A variety of Persian wraps likethekaunakes, with its lining of rough wool or the fringed cloak of Wasps 471, were brought into fashion. ${ }^{168}$ An onyx ring was worn on the finger. ${ }^{169}$

The fashion of the exquisites was set by Alcibiades.

He wal ks like one dissolved in luxury, Lets his robetrail behind him on the ground, Carelessly leans his head, and in his talk Affects a lisp. ${ }^{170}$

Theyoung bloods followed suit. One may hazard the suggestion that the babyish way of talking, upon which Socrates rallies Pheidippides, ${ }^{171}$ was an affectation of the young swell analogous to the clipping of the " $g$ " of participles familiar in this country before the war. It is fair, however, to notice that Alcibiades had a truelisp (he said "kolax" for "korax"), ${ }^{\mathrm{m}}$ while Pheidippides seems to have mispronounced the dipthong æ. The "Alcibiades shoe," at any rate became the mode, ${ }^{173}$ and probably a more rapid speech was considered good form by his youthful admirers than would have become Aristotle's megalo-psychos. ${ }^{174}$ And it is clear that a 
more emotional habit of phrase was coming in. The old col ourless form of greeting $\{\alpha \alpha i \rho \varepsilon\}$ gave way to $\{\alpha \sigma \pi \alpha \zeta o \mu \alpha 1\} .{ }^{175}$

LikePhilocleon, when emerging from his second chil dhood, Pheidippides had of course to master the elements of good form. The first importance was attached by Athenians to deportment. ${ }^{176}$ In dress he had to learn to put on his himation like a gentleman, not like an uncivilised Triballian, nor like Laispodias, who was compelled to wear his over the wrong shoulder in order to conceal his withered leg. ${ }^{177}$ And the art of sitting gracefully in a himation had to be acquired. ${ }^{178}$ And of course he would not be seen in the streets in clothes marked with stains, ${ }^{179}$ nor omit to put on summer clothes when the swall ow appeared. ${ }^{180}$

To walk properly was considered a sign of sophrosyne, that eminently aristocratic virtue, ${ }^{181}$ and the gentleman of fashion, noless than theHighminded Man, must affect a deliberate and leisurely gait. ${ }^{182}$ "It seems too," says Aristotle, "that theHigh-minded Man will besl ow in his movements, his voice will be deep and his manner of speaking sedate. For it is not likely that a man will be in a hurry if there are not many things that he cares for, or that he will be emphatic if he does not regard anything as important, and these are the causes which make people speak in shrill tones and use rapid movement." ${ }^{\prime 83}$

That nothing is to be regaded as important is one of the darling poses of youth in all ages, and is the real link between the young swell and the megal opsychos. The prejudice against walking fast and talking loud, like the money-lender Nicobulus, ${ }^{184}$ or stepping high like Aeschines and Pythocles, ${ }^{185}$ remains in the fourth century, but when the latter are accused of bad form in wearing cloaks down to their heels, it is due, probably, to an anti-aristocratic reaction against the dress of Alcibiades and the Thirty. Nicobulus' crimes were apparently aggravated by his carrying a stick. Everyone carried sticks in the fifth century, and that they did so still in the fourth is clear from Theophrastus. I can only suppose that in Nicobulus it was considered a piece of "swank" on the part of a despised money-lender.

The days of the young men, with whom Pheidippides was now associated, were spent in hunting boars, horse-racing, cock-fighting, and quail- 
W. R. Halliday, The Growth of the City State, 167

fighting. ${ }^{186}$ To all of these sports the young Athenian was passionately addicted. "I would rather have a good friend," says Socrates to a youthful hearer, "than the best cock or quail in the world; I would go even further, and say than a horse or dog." ${ }^{\prime 187}$ A less innocent recreation was dicing, and the young bloods in Athens, as in eighteenth century London, recklessly diced away their fortunes. ${ }^{188}$

Their evenings they spent at dinner-parties, and often Pheidippides and his friends will have dined at the house of Leogoras, the father of Andocides, himself a keen horseman, fond of entertaining and no doubt glad to attract round him the young men of the aristocratic party. ${ }^{189} \mathrm{~F}$ or the dinner-parties in the Wasps ${ }^{190}$ show us the employment of social functions for political ends, which reached its highest point in the organisation of the aristocratic clubs in which the extremists matured and engineered their coups d'etat in 411 and 403.

The beginning of the evenings was decorous enough. The young guests lay orderly upon their couches in the correct manner, as described to Philocleon by his son. ${ }^{191}$ But when the meal was finished, the manchets of bread on which they wiped their hands had been thrown to the dogs, ${ }^{192}$ the tables had been cleared away, the guests had washed their hands, ${ }^{193}$ and the loving cup of unmixed wine had been drunk by all to the toast of the Good Daimon, ${ }^{194}$ the drinking began, and things became increasingly lively.

No gentleman was a temperance crank or water-drinker, ${ }^{195}$ though of course a man of breeding would show it in the way he carried his liquor, and strong heads like Socrates' were much respected. The company el ected a president, who prescribed the toasts and the proportion in which the wine and water should be mixed. The normal mixture seems to have been three parts of water to two of wine. ${ }^{196}$ The president decided also (upon the expression of their wishes by the company) with what amusements the drinking should be accompanied. It would seem that the ol der fashion of the sing-song was temporarily out of mode, ${ }^{197}$ and if songs were sung, they were sad degenerate stuff, according to the older generation, licentious, pornographic nonsense, not the good old simple tunes. "J ohn Peel" and "Hearts of Oak" had been ousted by music-hall 
W. R. Halliday, The Growth of the City State, 168

impropriety. ${ }^{198}$ The conversation was much what one would expect. A great deal of hunting and athletic shop, and no doubt a good deal of personal exaggeration.

Tell how you slew the boar Or coursed the hare or ran the torch race. Tell Your youthfullest gayest act. ${ }^{199}$

Raconteurs - and one may suspect that their repertoire was more racy than Aesop, though probably as antique (for thereis nothing so old as the smoking-room story) - were in great request. The tactful raconteur was often a peacemaker, and could divert attention if guests were getting quarrelsome in their cups. ${ }^{200}$

Free women were not, of course, admitted to these entertainments. Flute players made music, and lavished their charms on the company, as may be seen on the vases as well as in the plays of Aristophanes. As the wine circulated the proceedings became more uproarious. The parties often fell to dancing. Indeed, the Greek felt that that man who danced without having "drink taken" was out of place; ${ }^{201}$ but the maudlin and unending dancing of Philocleon was equally to be deprecated by those who could carry their liquor like gentlemen. ${ }^{202}$

When the company got worked up, a rag not infrequently got under way. Sometimes the party would stagger off, wreaths and all, to visit someone else. The entry of Alcibiades in Plato's Symposium will be remembered, the most lively portrait I know in literature of the intrusion of one who has well-dined upon a more sober company. ${ }^{203}$ In the streets, the more hilarious would get into mischief, and damage would be done to the tradesmen's wares or premises, leading often to police court proceedings next day. ${ }^{204}$ Two of these rags were to have an important influence upon history. The brilliant idea of semi-intoxicated young aristocrats of carrying out a parody of initiation at the Mysteries and the drunken humour expressed in the mutilation of the herms which stood at the corners of Athenian streets, led to consequences which could not be averted by cash payments on the morrow.

Pheidippides' amusements were expensive. The pace was set by nouveaux riches like Diitrephes, who had made a fortune out of the manufacture of wicker shield-handles. ${ }^{205}$ It was all very well for the lad 
to complain in his cups of how short the old man kept him, ${ }^{206}$ but Strepsiades' income, which had been sensibly diminished, thanks to the destruction of his vines by the Spartan invasions, was al ready strained to meet the increase in the cost of living. Currency was inflated and commodities werescarce. Merchants continued to makelarge profits, and the munition makers were reaping a fortune, ${ }^{207}$ but the landowner watched his property being destroyed, and lost his harvests. Charcoal was scarce and oil increasingly difficult to procure. ${ }^{208}$ Even the slaves needed careful handling, whileskilled labour was extremely restive. It could only be controlled by concession, for since the war desertion had been easy. ${ }^{209}$ Rigid economy became increasingly necessary as the war went on. Meantime, the prodigal son was wasting money upon high living and the incidental expenses of vice. His father was always having to raise the wind to pay his racing debts, or to square the market women to avoid his appearance in the police court after some drunken frolic. And many a father, without the comic motive of acquiring a family interest in the Unjust Argument, must havedriven their sons to thesophists to continue their education during the awkward gap between school and military service. The problem is seriously discussed from a very different angle in Plato's Laches. There, too, the solution is Socrates.

If, on the one hand, parental pressure may have been applied, on the other philosophy becamethemodewith theyoung aristocracy. Alcibiades, whose disapproval had put an end to flute-playing as a social accomplishment, ${ }^{210}$ was the undisputed arbiter of fashion. His first association with the threadbare Socrates, if we may trust Plutarch, had aroused surprise and had seemed yet another of the pranks by which he courted public notoriety and kept the gossips busy. ${ }^{211}$ But his lead was followed, and phil osophy became the fashion. ${ }^{212}$ Already, in 423 , the older heads may have felt uneasy. Brilliant, beautiful, rich, reckless, and versatile, the younger generation, whose virtues and weaknesses Alcibiades embodied, represented that fine flower of the complete democracy, the democratic man of Plato's Republic.

A man so various that he seemed to be Not one but all mankind's epitome. ${ }^{13}$ 
Their lack of scruple, and the supple facility of their assimilation of the worse features of sophistic learning gave room for for eboding. Charming as appeared the embroi dered robe, its spangles lacked design. ${ }^{214}$ To the iconoclastic enthusiasm of youth, the new learning presented fatal attractions. The old restraints were removed, but no moral purpose was set in their place. Eagerly they learned the superiority of Nature's law over those conventions cantly termed morality, which the many weak have imposed on the few strong. ${ }^{215}$

They were to be a race of supermen; they became the Thirty Tyrants. The scene at the end of the Clouds is tragically prophetic.

O fool, fool, fool, how mad I must have been,

To cast away the gods for Socrates." ${ }^{16}$

cries the disillusioned old Athenian, and calls, in vain, upon his misguided son to help in the work of revenge.

Come, my darling,

Come and destroy that filthy Chaerophon,

And Socrates, for they've deceived us both."

Athens, too, had come to her senses with the restored democracy after the nightmare of the Thirty. J udged by its fruits, philosophy had been a worse guide than the religion it had destroyed, and Anytus, like Strepsiades, had cause to mourn a son for whose moral ruin he held Socrates to be responsible. On the facts, it is difficult to refuse some sympathy totheinfuriated fathers, however violent their revenge. In fact, the Socratic circle had produced, not only Plato and Xenophon, but Critias and the extremists of the Thirty. Socrates' personal virtue, his moral greatness, and his excellence of motive, are no more in question than the largeness of the debt to him of all subsequent ethical enquiry. But his method was analytical, and, in its immediate results, purely destructive. It destroyed the faith of his younger contemporaries in established standards, it did not teach them the intellectual humility of their master, whose personal faith in morality itself was not shaken by 


\section{W. R. Halliday, The Growth of the City State, 171}

the discovery that the sanctions of conduct of the ordinary man are inadequate or unworthy. Thestrong wine of intellectual freedom was too potent for clever but empty heads, and the result was disaster. Though the fault was that of the pupils not of the master, it was, one must admit, a sound instinct based upon bitter experience which inspired the plain man's hatred of the new learning. Nor can the crowd be altogether blamed for regarding Socrates as its representative. In this precisely lies the tragedy of a judicial murder as stupid and futile as it was unjust.

Notes to Lecture VIII.

1. See further Wilamowitz Moellendorff, Aristoteles und Athen II, 68.

2. Thucydides I, 6. Cf. Aristophanes, Knights 1331, Clouds 984, 1360. Athenaeus XII, 5.

3. Plutarch, Cimon, 5, 481. Cf. Aristophanes, Knights 580, Clouds 545, Birds 911, Wasps 466, Plutus 572.

4. Herodotus VII , 208. Cf. Plutarch, Lycurgus 22. According to Aristotle (Rhetoric I, 9, 1367a) long hair was the sign of a freeman at Sparta because it is not easy for one with long hair to perform menial work. Similarly in the modern Levant members of the black-coated class often let the nail of the little finger grow long, a practice which would be inconsistent with a peasant's work and therefore distinguishes them from their fathers. See further note 166 below.

5. "Now off at once with those confounded shoes,

And on with these Laconians instantly" (Wasps 1157, Cf. Thesmoph 142, Eccles. 345,). For their colour see Pollux, Onomasticon VII, 88.

6. The Man of Petty Ambition still affects the Laconian curve in Theophrastus VII , 20. In Aristophanes' day the Athenians habitually carried walking-sticks (Cf. Wasps 33, Birds 1283, Eccles. 73-5, 275-7).

7. Theocritus has described the athlete with his broken ears (Theocritus XXII , 45). For this outward and visible sign of Laconism among the Athenian aristocracy, see Plato, Protagoras 342b, Gorgias 515e, Aristophanes, Frag. 98.

8. Plutarch, Cimon 16, 488.

9. There was in Athens a Megacles, son of Megacles, the son of Hippocra- 
W. R. Halliday, The Growth of the City State, 172

tes, the son of Megacles, of Alopece, at the time when the Clouds was produced. Hewas secretary to the treasurer of Athena in 429/428 B.C., and therefore well-to-do (C.I.A., I, 122). But "uncle Megacles" is not the portrait of an individual but of a type (see Wilamowitz, op. cit. I, p. 111).

10. Aristophanes, Acharnians 703 foll.

11. Theophrastus XXIX, 22. I am inclined to think that the attitude of contemptuous abstention from politics was not unknown in the fifth century, and that there is latent a political taunt in Pericles' famous statement: "We are the only people that consider the man who takes no part in political life not as unofficious but as useless" (Thucydides II, 40).

12. Plato, Gorgias 514 foll.

13. Theophrastus XXIX, 20. Cf. Aristophanes Knights and Wasps, passim.

"And if, by Zeus, two orators propose One to build ships of war, one to increase Official salaries, the salary man Would beat the ships of war man in a canter."

(Knights 1350.)

14. Aristophanes passim. Perhaps the best description of the sycophant busybody is the scene in Plutus 900 foll.

15. Theophrastus XXIX. Cf. Pseudo-Demosthenes, in Theocr. 1342,65. Under the conditions of the restored democracy sycophancy became more rampant even than in Aristophanes' times, witness the orators passim and the enormous number of trials which the politician had to undergo in the course of an ordinary political career.

16. This was a cliche of the laudatores timporis acti (I socrates, Peace 74,174 , Aristophanes, Knights 1325). The change in the fifth century was from Philaids and Alcmaeonids to Cleon and Nicias analogous to that from the Pitts and Pal merstones tothe Gladstones and Chamberlains. Cleophon, the labour politician, did not come to the front until the cl ose of thePeloponnesian War. Cleon himself bel onged tothenew plutocracy. His father Cleaenetus paid for the training of a chorus somewhere about 467 B.C. (C.I.A. II, 971a), and was therefore no pauper. 
W. R. Halliday, The Growth of the City State, 173

17. "DEMOSTHENES : Spring you from gentlemen?

SAUSAGE SELLER: By the powers, not I, from downright blackguards.

DEM.: Lucky, lucky man. O what a start you've got for public life!

S.S. : But I know nothing, friend, beyond my letters, And even of them but little, and that badly.

DEM. : The mischief is that you know anything. To be a Demus' leader is not now F or lettered men nor yet for honest men, But for the base and ignorant."

(Knights 185 foll.)

18. $\{\alpha \mu \mathrm{or} \delta \varepsilon i \lambda \alpha i \circ \zeta$

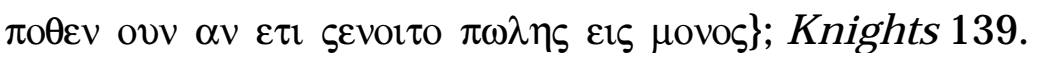

19. For the change in the manner of delivery in public oratory and the introduction of the popular style with violent gesture and shouting, see Plutarch Nicias 8 and Tib. Gracchus 2. Cleon was the first to use gesticulation; previous orators kept their arms inside their cloaks (Aeschines, in limarch. 25, Aristotle, Ath. Pol. 28, 3, Demosthenes, de

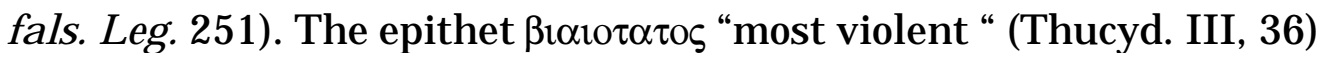
characterises Cleon's manner noless than his policy. For Cleon's highpitched, strident voice, bawling like a torrent in spate, see Aristophanes passim, e.g., Acharnians 381, Wasps 36, 1034, Knights 137, 218, Peace 314, 757, and compare Plutarch's story of Gaius Gracchus (who similarly introduced mob oratory into Roman political life) and the pitch pipe.

20. It is clear from the Knights that Cleon was fond of appealing to popular religious sentiment and made great play with oracles. He used the trick of introducing slang (eg., \{to $\rho v \pi \pi \alpha \pi \alpha 1\}=$ "the lower deck," from the sailors' cry at the oars (Wasps 909)) or homely metaphor (Knights 461, foll.) to give vivacity to his speeches. He was

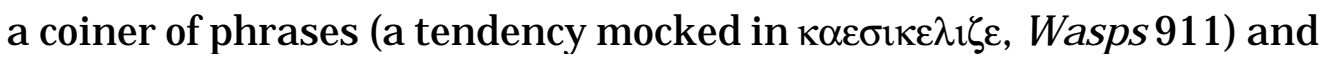
liked to employ oratorical turns which had become proverbial, with a new twist (eg., $\left\{\varepsilon \alpha \sigma \tau \eta \tau_{s} \tau o v \Delta \eta \mu o v,\right\}$ Knights 732, II6z. It is curious that $\mathrm{Mr}$. Rogers has not noticed that the original phrase is filched from Pericles, Thucyd. II , 43, and given a new turn). He employed personal vituperation and misrepresentation without scruple as a 
W. R. Halliday, The Growth of the City State, 174

political weapon, and madelarge use of promises, not al ways fulfilled, of the benefits to accrue to the masses from the spoliation of the rich. $\mathrm{H}$ is enemies alleged that political power was turned to personal profit. Modern analogies are not perhaps unknown.

21. Knights 1300-1315.

22. "And Demus that is what he always does: Gives you the pettiest morsel of his gains And keeps by far the largest share himself."

(Knights 1221.)

This is of course the main theme of the Wasps; of. especially II 665 foll.

23. Theophrastus XXIX.

"Now please remember, justices, yell have No barley if the prisoner gets off free" (Knights 1359).

24. Knights 912, Theophrastus, XXIX, Xenophon, Oecon-omicus II, 5.

25. Xenophon, op. cit. I, 17. With the great increase in the cost of living and the financial losses of the great war, the upper classes were in many cases forced into working in the fourth century. Thus Aristarchus' difficulties were solved by following Socrates' advice to turn his female dependents on to work at weaving and spinning (Xenophon, Memorabilia II, 7).

26. Clouds 815.

27. With the greater luxury of imperial Athens frescoed halls had come into fashion (Plutarch, Alcibiades 16). Alternatively the halls of the great wereadorned with embroidered hangings (Wasps 1215). Persian tapestries with designs of fantastic monsters were admired (Frogs 937). The Man of Petty Ambition affects hangings with Persians embroidered on them (Theophrastus VII).

28. Xenophon, Oeconomicus II, 5.

29. "Again a magnificent man will erect a house in a manner suitable to his wealth, for even a private house may be an ornament to the city" (Aristotle, Ethics IV , 2, 11233). Thus Alcibiades claims that "these doings of mine for which I am so much cried out against are an honour to myself and my ancestors, and a solid advantage to my country" (Thucydides VI, 16. Cf. Demosthenes Adv. Phaenipp. 1046, 24).

30. [Xenophon] Constitution of Athens I, 10. 
W. R. Halliday, The Growth of the City State, 175

31. For fairs at the New Moon at which slaves were purchased, see Knights 43, Wasps 171.

32. This price was paid at the sale of the Hermokopid's property (Hicks and Hill, Gredk Historical Inscriptions, No. 72). At this sale two Syrians fetched $240 \mathrm{dr}$. and $301 \mathrm{dr}$. respectively. Male Thracians run from $115 \mathrm{dr}$. to $195 \mathrm{dr}$., and female Thracians from $156 \mathrm{dr}$. to $220 \mathrm{dr}$. After Alexander's conquests, black slaves became the fashion, as in England in the eighteenth century, and the Man of Petty Ambition is concerned to be accompanied by an Ethiopian attendant (Theophrastus VII ). They were fashionable also in Rome; illi sint comites fusci, quos I ndia torret, | Solis et admotis inficit ignis equis (Tibullus II, iii, 55-56).

33. The Odeum, built by Pericles, whose high bald head was likened by the comic poets to its dome (Plutarch, Pericles 13), was the seat of the alimony courts (Wasps 1109). The Oligarchic Man in the fourth century took his constitutional in Odeum Street (Theophrastus XXIX). For theminimum of threeattendants, seeDemosthenes, Phormi 0958, 45.

34. Herodotus VI , 125. According tothestory, Croesus told Alcmaeon that he might take as much gold as he could carry away on his person. Alcmaeon not only filled the fold of his garment, his mouth, and a pair of extra large buskins donned for theoccasion, but even sprinkled gold dust in his hair.

35. Herodotus V, 62. Cal umny suggested that if thereal facts were known the Alcmaeonid contractors made handsome pecuniary as well as political profit out of the transaction (Schol. Demosthenes' Meidias XXI, 144, Müller II, 685).

36. Clouds 23.

37. Theophrastus XVII, 15, Lysias, de inval. 20, 170, Demosthenes, in Arist. 51,786. Theophrastus called thebarbers' shops $\{\alpha o v \alpha \alpha \sigma \mu \pi 0 \sigma i \alpha\}$, (Plutarch Symp. V. 5). For barbers' and perfumers' shops as places for gossip in Aristophanic times, see Birds 1441, Plutus 338.

38. Birds 300. Sporgilus was what Athenians called "a bird," see 11. 166 foll. 
W. R. Halliday, The Growth of the City State, 176

39. The Offensive Man goes about with his nails long (Theophrastus XII). The Oligarch has his nails delicately pared and his hair daintily trimmed (Theophrastus XXIX). The Man of Petty Ambition will have his hair cut frequently (Theophrastus VII).

40. Cf. conversation between Critobulus and Socrates in Xenophon, Oeconomicus II, 3.

41. Plutarch, Alnbiad.es 16.

42. "Why till ye built this city in the air

All men had gone Laconian mad.

They went Long-haired, half-starved, unwashed,

Socratified, With scytales in their hands." (Birds 1280.)

Aristotle shrewly points out that this pose of ascetism is a form of boastfulness, "for exaggerated deficiency is a form of boastfulness as well as excess" (Ethics IV, 7, 1127b).

43. Thucydides II , 38. [Xenophon] Constitution of Athens II , 7-8. For a list of imports see Hermippus, frag. 63 (Kock) ap. Athenaeus I, $27 \mathrm{~d}$-c. Its geographical advantages madePiraeus thecentral mart even after the loss of the Athenian empire (Xenophon, Ways and Means I, 6).

44. The bulk of Greek trade was in luxuries and necessaries. The second were of national importance, and tended therefore to be controlled by the State. Regulations to secure adequate cargoes of corn, to prevent the diversion of the Black Sea supplies elsewhere and to control their distribution after arrival at Piraeus, were rigidly enforced by Athens. The timber trade, essential to a maritime power, was also subject to interference by theState. A minor instance of State control of the raw materials of a "key industry" is to be seen in the inscription providing for the Athenian monoply of Cean ruddle used for Attic pottery (Hicks and Hill, No. 137). Luxuries were the more profitable cargo to the trader, and rarities were in constant request (Cf. Aristophanes, Acharnians 900 foll). Hence the truth of Herodotus' observation that the most valuable of commodities are to be found at the end of the world (Herodotus III, 106).

45. Archilochus is the first Greek author tomention the monkey. There are many references to monkeys in Aristophanes (eg., Acharnians 
907, Frogs 707, 1085) and the Man of Petty Ambition kept a monkey and a satyr ape (Theophrastus VII). Monkeys were popular in later antiquity and Lucian compares the dependent scholar to a pet monkey with a collar round his neck who is fed on dried figs (demerced. cond. 25). Compare the pet of the king of the Molossians (Cicero, de div. I, $34,76)$ and the story of the performing monkey which forgot its tricks upon seeing somenuts and figs (Lucian, Apol ogia 5I , 713 and Piscator 36). Greeks were much addicted to keeping pets. The complaint, which still recurs in "the silly season," against the old maid who lavishes affection upon a lap-dog which would be more properly bestowed upon a child, though fathered by Plutarch upon Iulius Caesar (Plutarch, Pericles I) in reality goes back to the Middle Comedy (Eubulus, Frag. 115 , Kock), the pets specified being geese, sparrows, and monkeys. Peacocks were still a novelty in Aristophanes' day. "Are you bird or peacock?" Euel pides asks Tereus (Birds 102). For Pyrilampes' peacock farm, see below, note 138. Possibly Leogoras kept an aviary of pheasants (Clouds 109) which wereal so of recent introduction, though I am inclined to think that Rogers and the other champions of "Phasian horses" are in the right, in view of the context and the known horsey character of the father of Andocides.

46. Ischomachus' wife married before she was fifteen. Xenophon (Oeconomicus VII, 5). Aristotle (Politics VII, 16) and Hesiod (Works and Days 698), if I understand him aright, favour a later age upon eugenic grounds, and Spartans, as contrasted with other Greeks, practised the sounder doctrine (Plutarch, Lycurgus, 15). Plato lays down the marriageable ages as 16-20 for women and 30-35 for men (Laws VI, 787).

47. Clouds 41. Cf. Xen. Mem. II, 6, 36.

48. Theophrastus XIV, 11.5 and 28.

49. A deme of Acamantis. For the property see Clouds 134, 210.

50. Pheidon ("Stingy") became a stock character in Middle Comedy, see Athenaeus VI, 223. A similar play upon the name Pheidon and Pheidonian measures occurs in Theophrastus XXVI. Cf. the story of Phryne's retort to the mean lover, Athenaeus XIII , 49. 
W. R. Halliday, The Growth of the City State, 178

51. Xenophon Oeconomicus VII , 5. Cf. ib. III, 13. Thucy-dides II , 45.

52. "My business, my mother told me, was to be modest " ( $\{\omega \varphi \rho \circ v \varepsilon i v\})$ Xenophon Oeconomicus VII, 15. The training in this case seems to have enabled the girl to live happily with a prig.

53. Thesmopb. 289-290.

54. Saffron robes (Eccles. 331, Thesmopb. 253). Cimmerian vests (Lysistrata 44). Thespangled robewhich women love, (Plato, Republic 557c). For the question whether silk had yet come into use at this date, see Seeker's Charikles. It would seem to have been a rarity still in Aristotle's time.

55. Milesian wool (Lysistrata 729). Amorgos linen (ib. 48, 150).

56. Hesiod, Op et Di 800.

57. Gamelion. Aristotle (Politics VII, 16, 1335a) agrees, with popular custom that the winter months are the most suitable for marriages.

58. Plutus 529, Birds 1693. For perfuming of bride and bridegroom, cf. Peace 862, Lysistrata 938.

59. Clouds 51.

60. Xen. Oec. X, 2 foll. For use of white lead and alkanet as aids to beauty, cf. Aristophanes, Eccles. 878, 929, 1072,. Lysistrata 48, Plutus 1064. Girls who wished to appear taller put cork soles in their shoes. For these, bustles, and other feminine devices, see Alexis ap Athenaeus XIII, 23.

61. Clouds 53. Spinning, weaving, and cooking were essential qualifications in a wife (Xenophon, Oeconomicus III, 6), but in Ischomachus' view the most important qualification is the power of organisation. The good housewife should have her houseas tidy and as methodically arranged as a ship (ib. III , 15, VII , 32). Plato (Laws VII , 805) states and criticises the view that woman's sole vocation is managing the house. "Or shall we do as we and people in our part of the world do? Getting together, as the phrase is, all our goods and chattels into one dwelling - these weentrust to our women, who are stewards of them; and who al so presi de over the shuttles and the whol e art of spinning."

62. Thesmophoriazusae, 418 foll. The interest taken by the master in the details of housekeeping was, in fact, more marked towards the end of 
the Peloponnesian War, for reasons painfully familiar to these days (see Frogs 980 foll). Domestic quarrels over housekeeping recur frequently in the later plays of Aristophanes.

63. Lyiistrata, 658.

64. Birds, 440 foll.

65. Clouds, 45.

66. Clouds, 50.

67. Thesmoph. 512.

68. Greeks settled in foreign countries sometimes gave their children foreign names, e.g., Psammetichus, son of Theocles (Hicks and Hill, No. 3), or great personages might cement diplomatic ties by naming their children after a foreign potentate or an allied community, eg., Psammetichus, nephew and successor to Periander, or Lacedaemonius, Thessalus, and Eleius, the sons of Cimon.

69. Analogous to the "Almas" of the Crimean War or the "Irenes" of the Boer War are names like Carystonicus and Naxiades (Hicks and Hill, No. 46, note). I am told that Armistice is now not uncommon as a name among the younger generation in a certain social stratum.

70. The most usual practice (cf. Plato, Laches 179, Aristophanes, Birds 283). The eldest son had a more or less recognised right to his grandfather's name. Sometimes, li ke Megacles or Demosthenes, a son was called after his father, often the father's name was given with a slight change of form. Full references are to be found in Becker's Charikles. As is usual in societies where surnames are not devel oped, people werelargely desi gnated in practiceby nicknames likeB attalos, K robylos, etc. (See Birds, 1290 foll).

71. Clouds 60 foll.

72. Birds 494, Theophrastus VIII.

73. "Thus the most beautiful of balls or bottles has a certain magnificence as a present for a child, though its price is trifling and paltry. It is characteristic, then, of the magnificent man, whatever be the class of work that he produces, to produce it in a magnificent way" (Aristotle, Ethics IV , 2, 1123a). "Children should have something to do, and the rattle of Archytas, which people give to their children in order to 
amuse them and prevent them from breaking anything in the house, was a capital invention, for a young thing cannot be quiet" (Aristotle, Politics VIII ,6, 1340b). J ulian in thethird century after Christ alludes to leathern "soothers" which nurses attached to the hands of teething children (J ulian, Or. VII, 206D).

74. Birds 492 foll. For the state of Athenian streets in the dark, cf. Wasps 246. Link boys were of course a necessity, except in the brightest moonlight (Clouds 612, Peace 839. Plutarch, Pericles, 5). For Orestes the footpad, see Acbarnians 1164, Birds 1490.

75. Thesmoph. 730. It was cut rather than material that is characterised by $\{\kappa \rho \eta \tau \leftarrow \kappa o v$.$\} In its proper sense the Cretan robe was a very short himation$ worn by the King Archon (Pollux VII, 77). Hence probably "shortening clothes" or "pelisse." Persian slippers are the feminine footgear as opposed to the masculine Laconian shoes (Eccles 319, 345). The little shoes of wax made in the flea experiment are Persians (Clouds 151), and Pollux says that they were light coloured $\{(\lambda \varepsilon v \kappa \circ v v \pi \circ \delta \eta \mu \alpha)\} \mathrm{VII}, 92$.

76. Clouds 1381.

77. Spartan nurses were the fashion in Greece (Plutarch, Lycurgus 16). Alcibiades had a Spartan nurse named Amykla (Plutarch, Alcibiades I).

78. "And feed him badly as the nurses do,

You chew and pop a morsel in his mouth,

But thrice as much you swallow down yourself."

(Knights 716.)

For pap feeding in second childhood, see Athenaeus XII, 40. For Strepsiades' behaviour, see Theophrastus XI.

79. Plutarch, Agesilaos 25.

80. The Stupid Man makes his children wrestle and run races until he has exhausted them (Theophrastus XIII).

81. Aristophanes, Frag. 389; Pollux VII. $\{\varepsilon \xi \varepsilon \chi \omega \varphi \iota \lambda \eta \lambda \iota \varepsilon\}$ is the Mediterranean counterpart to the "Rain, rain, go to Spain" of our more negative climate.

82. Clouds 878. In the second century after Christ the school boy Lucian was caned for scraping the wax off his writing tablets and modelling 
W. R. Halliday, The Growth of the City State, 181

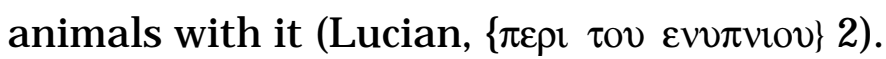

83. Wasps 824 foil. Labes the house-dog (Wasps 836). The stables were just inside the front door (Wasps 179). For the use of the pig pen to make the court, see Wasps 844.

84. The figs were dangled in front of the child, who tried to catch them with his mouth (see Knights 755).

85. Clouds 861.

86. The performing jackdaw as pet (Theophrastus VII). Philocrates the bird-seller is mentioned (Birds 14). His prices were one obol for a jackdaw, three obols for a crow, and siskins seven an obol (Birds 18, 1077).

87. For figs and knuckl ebones as acceptable offerings to a boy, see Wasps 291 foll. Knuckl ebones were used not only in the modern way, but al so with nuts and acorns in a variety of marble games (See Pollux IX, 102). The Flatterer buys "apples and pears and will bring them in and give them to the children in the father's presence, adding with kisses 'Chicks of a good father '"' (Theophrastus I). The Flatterer's phrase corresponds to our "Chip of the old block," and was proverbial (cf. Birds 767).

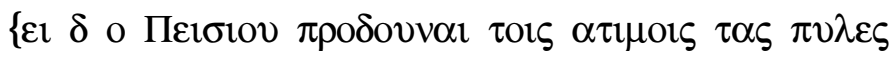

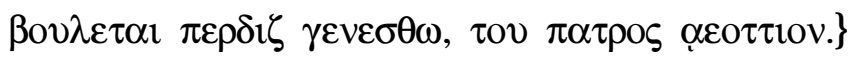

88. The Complaisant Man "when asked to dinner will request the host to send for the children and will say of them when they come in, that they are as like their father as figs; and will draw them towards him and kiss them and establish them at his side - playing with some of them, and himself saying 'Wineskin Hatchet,' and permitting them to go to sleep upon him to his anguish" (Theophrastus II). Xenophon, Symp. I, 8, shows us an ol der boy at a dinner of grown-ups. He does not recline like his elders, but sits.

89. "Nay he (the Loquacious Man) will endure to be the butt of his own children when drowsy, at last they maketheir request to him in these terms, ' Papa chatter to us that we may fall asleep'" (Theophrastus $\mathrm{XIX).}$

90. Clouds 71. 
W. R. Halliday, The Growth of the City State, 182

91. Peace 133, Lysistrata 695, Wasps 1448.

92. Wasps 1182.

93. Lysistrata 781.

94. F uther references to Aesop Birds 471, Wasps 1401, 1446. For nurses' tales and the evil of frightening small children with bogey stories, see the references in Becker, Charikles. For children's fear of the dark see Plato, Phaedo, 770.

95. Aristophanes, Anargyros, frag. 41.

96. Clouds 69.

97. Plato suggested that physical education should begin at six, literary at ten and musical, in our sense of the word, at thirteen (Laws VII, 794). Aristotle begins education both physical and literary at seven (Politics VII , 17). In practice the age at which children began going to school varied; the sons of the well-to-do classes tended to begin earlier. Plato's discussion on education in the Laws is exceedingly interesting. He tacitly abandons adult education which he had made the foundation of his visionary state in the Republic, but in what he considered a practicable ideal state, he touches upon much that is germane to modern educational theories. He believes in equality of educational opportunity between the sexes but not in co-education after the age of six. Noticeable is his insistence on the formative influence upon character exercised by children's games. Between the ages of three and six the children play in what may fairly be called a state kindergarten.

98. Nicias made his son learn thelliad and Odyssey by heart to make him a good man. If his table-talk is fairly reproduced he made him a bore (Xenophon, Symp. III, 5. Cf. Aeschines in Ctesi pbon 135). To be able to quote Homer was a feature of liberal education. The Late Learner studied passages for recitation when he was past sixty and always broke down when he tried to deliver them over the wine (Theophrastus VIII). The oligarch has only master ed one line, "No good comes of manifold rule, let the ruler be one " (Theophrastus XXIX). For boys rehearsing for a speech day at a wedding feast, see Peace 1268 foll. Recitations were a recognised social diversion over the wine (Clouds 
W. R. Halliday, The Growth of the City State, 183

1364).

99. Knights 189.

100. In Protagoras 325, Plato lays stress upon this point. "At a later stage they send him to teachers and enjoin them to see to his manners even more than his reading and music and the teachers do as they are desired" (Cf. Laws VII, 819. "F or entire ignorance is not so terrible or extreme an evil and is far from being the greatest of all: too much cleverness and too much learning accompanied with ill bringing up, are far more fatal.)" The Greek for "I am not an intellectual" is

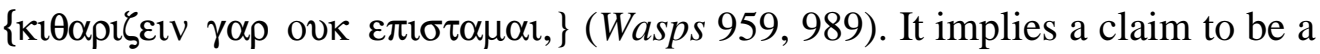
plain honest man like Laches. Compare Ion's story of the retort of Themistocles $\{\varepsilon \kappa \varepsilon i v o v \gamma \alpha \rho \alpha \delta \varepsilon i v \mu \varepsilon v$ ov $\varphi \alpha v \alpha l$

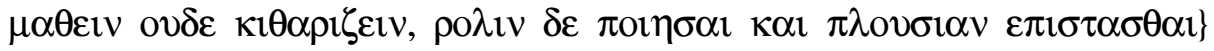

(Plutarch, Cimon, 9). Of course, on the other hand, in polite society the intellectual pose is effective and at least an apparent knowledge of prosody can be turned to uses of display (Clouds 649).

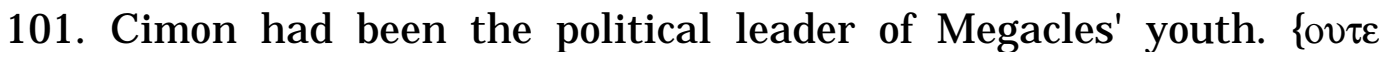

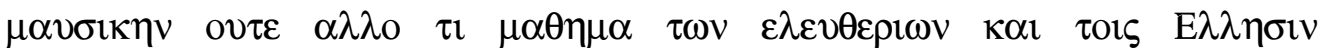

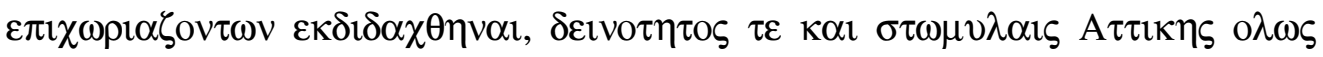

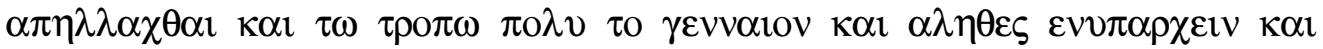

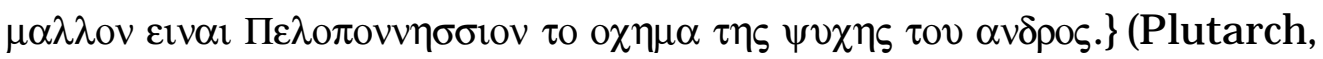
Cimon 4, 480). For the physical results of an over-intel lectual training, see Clouds 1015 foll. For the authentic Attic look, Clouds 1170-6.

102. Clouds 962, 993.

103. Clouds 987.

104. Clouds 964 foll.

105. Clouds 1044 foll. The hot bath controversy was evidently acute at the time (cf. Athenaeus I, 32). The hot bath, however, camein, in spite of old-fashioned opposition (Xenophon, Mem. III , 13, 3), and in Aristophanes' own day the public baths were a refuge for the destitute in col d weather (Plutus 535, 952). I n thefourth century, theE vil Speaker says of a man that he even makes his wife wash in cold water upon Poseidon's day (Theophrastus XXI). Thewriter remembers a comment very similar to that of Megacles made by his grandfather, an old 
Wykehamist, upon the laying-on of hot water in College at Winchester, a blessed innovation which took place as lately as his school-days. 106. Birds 139.

107. Aeschines, in Timarchum iz. The punishment under Sol on's law was death, but the law was clearly a dead letter. When Socrates comes home from the front, he drops in at the palaestra of Taureas, sure of meeting friends there (Plato, Charmides $153 \mathrm{~A}$ ). A palaestra is the scene of the Lysis. Theresults of the practice were undesirable (Wasps 1025, Peace 762). Eupolis, the comic poet, was notorious for this objectionable hobby, and Aeschines (in Ctes. 216) repudiates a similar charge.

108. "He will go into the schools and palaestras and hinder the boys from getting on with their lessons by chattering at this rate to the trainers and masters" (Theophrastus XIX).

109. Clouds 977.

110. Demosthenes, de Corona 312-313.

111. The law prescribed that the schoolrooms should be opened not earlier than sunrise and close not later than sunset (Aeschines, in Timarch 2). Ancient Greeks, like the modern Greek peasant, began their day's work with the sun (eg., chorus of Wasps groping their way into the town before dawn) and slept longer in winter than summer (eg., Plato, Symposium 223b). When the Thracian mercenaries sacked Mycalessus at dawn, the school had already assembled (Thucydides VII, 29). "When the day breaks, the time has arrived for youth to go to their school masters" (Plato, Laws 818).

112. "Suddenly we were interrupted by the tutors of Lysis and Menexenus, who came upon us likean evil apparition with their brothers and bade them go home as it was getting late. At first we and the bystanders drove them off, but afterwards, as they would not mind and only went on shouting in their barbarous dialect and got angry and kept calling the boys - they appeared to us to have been drinking rather too much at the Hermaea, which made them difficult to manage - we fairly gave in and broke up the company" (Plato, Lysis 222). 
W. R. Halliday, The Growth of the City State, 185

113. Melitean dogs werefavourite pets (Theophrastus VII ) and frequently appear on the vases. I am inclined to agree with J ebb that Pliny's statement that they came from the modern Meleda near Curzola in the Adriatic (Nat. Hist. III, 26) is more correct than the more obvious Maltese derivation (Strabo. VI, 2.).

114. For a description of a Melitean dog peering out of the fold of the cloak in which he is being carried, see Lucian, de merced. cond. 34. Vases depicting school life represent the boys' dogs as being present in the school room.

115. An excellent account of primary education with references to all the pertinent passages will be found in Freeman, Schools of Hellas.

116. Clouds 799.

117. Clouds 1005. For chums, cf. Lysis and Menexenus in Plato Lysis.

118. Clouds 1007.

119. Clouds 963.

120. Clouds 981.

121. Clouds 973. Cf. Plato, Charmides 155.

122. Clouds 993.

123. Clouds 983.

124. Clouds 962, 1001, with Rogers' notes.

125. Knights 855, Plato Republic 521, Phaedr. 241b. The game is described in Pollux IX, 111-112. A kind of prisoners' base. A line was marked between thetwo sides, one of which was "Night" and the other "Day." A piece of potsherd, black one side and white the other, was tossed up. If white came uppermost, "Day" were the pursuers, and "Night" had to get home before being caught. A catal ogue of games is, of course, to befound in Pollux, which includes tug-of-war, blind man's buff, and hide-and-seek. Athenaeus XIV , 27, mentions a game called "Posies" which sounds very similar to "Here we come gathering Nuts in May." The refrain is

"Where are my roses and where are my violets?

Where is my beautiful parsley?

Are these then my roses, are these then my violets?

And is this my beautiful parsley?" 
A number of singing games will be found collected in the section Carmina Popularia in Bergk, PoetaeGraeci Lyrici III I I have discussed some of them in Discovery III, (Dec. 1922) p. 324.

126. Plato, Theaetetus 146. A variety of ball games are described in Pollux IX, 104 foll. Plato, Phaedr. 110b, compares the earth to a ball, the cover of which consisted of 12 pieces of col oured leather sewn together. The very remarkable reli efs of sixth century B.C. discovered in Athens in 1922 show a ball game in progress and also what can only be described as a game of hockey. The reliefs are reproduced in J ournal of Hellenic Studies XLII, Plates VI and VII.

127. Anthology VI, 308. A prize of 80 knucklebones given by the master to Konnaros for calligraphy. The evidence is, of course, Alexandrian in date, Asclepiades, master of Theocritus, being the author of the epigram. There is no earlier evidence for school as opposed to State prizes, see Freeman, Schools of Hellas, pp. 62 foll.

128. For odd and even played sometimes with dice, knucklebones, or nuts, sometimes with the fingers (Plutus 816, 1056, Plato, Lysis, Pollux IX, 101. Cf. Horace, Sat V, 248).

129. Thesmoph. 273.

130. "All through Anthesterion he (the Avaricious Man) will not send them to their lessons because there are so many festivals and he does not wish to pay the fees" (Theophrastus XXVI). School masters were paid monthly. For a schoolmaster whose fees were not paid, see Demosthenes in Aphob, I . 828. TheAnthesteria, Lesser Mysteries, and Diasia, all fell in Anthesterion, and not only were these holidays, but it was also customary to make presents to the schoolmaster in cel ebration of them.

131. The Mean Man "is apt also not to send his children to school when there is a festival of the Muses but to say that they are unwell in order that they may not contribute" (Theophrastus XXV).

132. "And lots of other monkey tricks I practised as a boy, $O$ how I used to chouse the cooks by shrieking out 'Ahoy Look, lads, at the swall ow! Spring is here. Look up, I pray.' So up they looked while I purloined a piece of meat away." (Knights 417.) 


\section{3. "We'd got one drachma}

Betwixt us two; he changed it at the fish-stall; Then laid me down three mullet scales: and I, I thought them obols, popped them in my mouth; O the vile smell! O la! I spat them out." (Wasps 788.)

134. Cockchafers on a string (Clouds 763). For the puerile device of incendiarism by tying a light on to such a cockchafer see Acharnians 920.

135. Birds 501. Greek garments had no pockets. Larger articles, such as papers (Theophrastus XVI), vegetables (Theophrastus XXV), or lapdogs (Lucian, demerced. cond. 34) could be carried in the folds of the himation. Small change, of necessity, was carried in the mouth (Cf. Aristophanes Wasps 791, Eccles. 818, Aeolosicon, Frag. 3, Anargyros, Frag. 48, Athenaeus III, 10). This is probably one of the reasons why Attic small coins were of silver. The only issue of copper small change (Aristoph. F rogs 720-6) was soon withdrawn (see P. Gardner, History of Ancient Coinage, pp. 226, 295).

136. Aristophanes, Daitales, Frag. 222.

137. Conjurors became increasingly popular in the fourth century, and the names of the most celebrated have survived : Scymnus of Tarentum, Philistides of Syracuse, and Heraditus of Mitylene (Athenaeus XII , 54). Public performances with travelling booths (Plut. de fac. Lun. 8). Entertainments at private dinner parties, see Xenophon, Symposium, where a female acrobat juggles with twelve rings while dancing, and turns somersaults into a stand round which sharp knives are set. For illustration, see Blumner, Home Life of Ancient Greeks, Figs. 99, 100. Familiar tricks were bringing fire from mouth (Athenaeus IV, 129), knife swallowing (Plutarch, Lycurg. 19), or making pebbles pass from one cup to another, or extracting them from mouth or ears of spectators (Al ciphron III , 20). One of Plutarch's favourite Laconian apothegms shows us the imitator of song-birds (Plutarch, Lycurgus 20, Agesilaos 21). Conjurors also gave puppet shadow plays (Plato, Republic VII, 14, Laws II, 658. See further Becker, Cbarikles, Scene $X$, and notes).

138. For Pyrilampes and his peacock farm, see Plutarch, Pericles XIII , 6. 
W. R. Halliday, The Growth of the City State, 188

Plato, Charmides 158. Athenaeus IX, 56, 397 c.d. Peoplecamefrom all parts of Greece to see the birds, and the public had to be limited to certain specified visiting days. For Demos, son of Pyrilampes, see Wasps 97.

139. Boys evidently attended the theatre in fifth century (Clouds 539, Peace 50, 766). In the fourth, the Shameless Man manages to get his sons and their pedagogue, as well as himself, into the seats paid for by his foreign friends (Theoph. XV), and the Avaricious Man "seizes the opportunity of taking his boys to the play when the lessees of the theatre grant free admission" (Theoph. XXVI).

140. Plato Lysis; Theophrastus XXV; Aeschines, In Timarchum 10.

141. Plato, Lysis 206. White clothes are the regular gala attire (Acharnians, 1024); thus the Man of Petty Ambition "having provided himself with a smart white cloak and put on a wreath," reports the auspices (Theoph. VII). Cf. Demosthenes' behaviour on the death of Philip (Aeschines, Ctesiphon 46, 77). In the second century after Christ white clothes were obligatory at thePanathenaic festival (Lucian, Nigrinus, 14).

142. Wasps 1056.

143. Theophrastus XXV. Socrates gets a present of a sack of meal (Clouds $669,1146)$.

144. "As this is the festival of the Hermaea the young men and boys are all together and there is no separation between them" (Plato, Lysis 206).

145. "U pon entering we found that the boys had just been sacrificing; and this part of the festival was nearly at an end. They were all in white array, and games at dicewere going on among them. Some werein the outer court amusing themselves; but some were in a corner of the Apodyterium playing at odd and even with a number of dice which they took out of little wicker baskets" (Plato, Lysis 206).

146. Plato, Lysis 222.

147. Plato, Lysis 208.

148. Plato, ibid.

149. Clouds 1409. Description of boy waiting to be beaten (Wasps 642). 
W. R. Halliday, The Growth of the City State, 189

150. Clouds 79.

151. "That grown-up men like ourselves should have been affected in this way was not surprising, but I observed that there was the same feeling among the boys; all of them, down to the very least child, turned and looked at him as if he had been a statue (Plato, Charmi des 154).

152. Clouds 998. For the way in which the new education undermined parental discipline compare Plato, Republic VIII, 5626. foîov ह̌ $\varphi \eta v$,

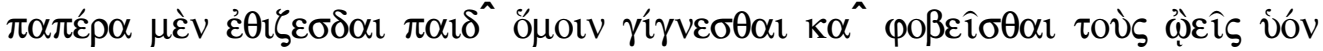

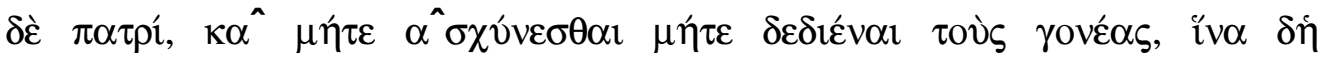
$\left.\varepsilon \lambda \varepsilon \dot{v} \theta \varepsilon \rho \rho_{\text {กิ. }}\right\}$

153. Aristophanes, Daitales, Frag. 216.

154. Aristophanes, Daitales, Frag. 221.

155. Clouds 124.

156. Aristophanes, Daitales, Frag. 221.

157. Athenaeus XII , 16. Timaeus' story was that one young Sybaritetold another how the sight of a man digging had positively given him a pain in his back. "Stop, my dear fellow," said the second, "merely hearing of it has given me the deuce of a stitch."

158. Aristophanes, Knights 1375 foll. Aeschines, in Ctes. 255.

159. Acharnians 88, Wasps 19, 592, 822, Birds 1475.

160. Clouds 355, Acharnians 118, Knights 1374, etc.

161. Wasps 1280, Peace 883.

"Whoso loathes not such a monster never shall be friend of mine, Never from the selfsame goblet quaff with me the rosy wine." (Knights 1285.)

162. Eceles. 647, Plutus 314. The Man of Petty Ambition "will have his hair cut very frequently, will keep his teeth white; he will change his clothes too while still good" (Theoph. VII).

163. "How could I face the knights with all my colour worn and torn away" (Clouds 119). The phil osophers are unwashed and pale (Clouds $101,837)$. "These then are the mighty secrets you have picked up amongst those earth-born fellows" (Clouds 852-3). All Athenians were earth-born (Cf. Wasps 1076, Lysistr. 1082). See further above Lecture 
W. R. Halliday, The Growth of the City State, 190

IV, note 9, p. 101.

164. Amynias, the long-haired swell and gambler (Wasps 74, 466).

Shirked military service (Clouds 690).

165. Knights 576 foll.

166. "Slim as an eel with gol den ringlets" (Aristophanes, Daitales, frag. 218. Wasps 1069). Pheidippides' long hair (Clouds 14). Cf. Knights 1121, Lysistrata 561 . Thus wearing long hair means "to put on side" (Clouds 545, Wasps 1317). See notes 3 and 4 above.

167. Acharnians 849. The vicious fop, brother of Hegesander, was nicknamed Krobylos (Aeschines, in Timarchum, 64, 71, in Ctes. 118). 168. Wasps 1137. 1142.

169. Clouds 332.

170. Plutarch, Alcibiades I. The description is of Alcibiades' son, but the point of attack is his imitation of his father's poses.

171. Clouds 872.

172. Wasps 44-46. Plutarch, Alcibiades I.

173. Athenaeus XII, 47. Pollux VII, 89.

174. Plutarch, loc. cit. "It is said that his lisping, when he spoke, became him well and gave a grace and persuasiveness to his rapid speech." Ready and rapid speech was a characteristic of his uncle Pericles, a point of resemblance to Peisistratus (Plutarch, Pericles 7).

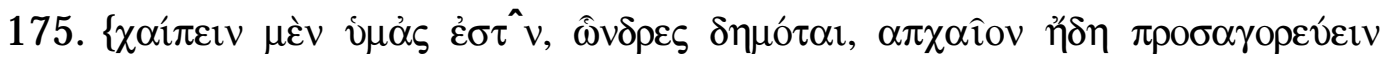
$\kappa \alpha^{\wedge} \sigma \alpha \pi \rho o^{\prime} \alpha \sigma \pi \alpha \xi o \mu \alpha \imath \delta^{\prime}$.\} (Plutus 322.)

176. Plato, Theaetetus 175. Theophrastus XXIX.

177- oSros rl Spas; AT* Apurrtp' oSrus

oil / j.eraf\}a.I f!s Boln\&TiOV S>S ' (iriSi ia,;

rt \& KanoSai/ iuv; Aaunrol tes ef rty (fujcnv; (Birds 1567.)

178. The Boor "wearing a cloak which does not reach his knee will sit down " (Theophrastus XIV). The Penurious Man wears a short cloak (id. XXIV.) In the Protagoras the short cloak is regarded as an affected Laconism (Plato, Prot. 3420).

179. A mark of the Offensive Man (Theophrastus XII).

180. F or changing clothes when the swallow appears, see Birds 714. The Offensive Man goes about in a thick winter tunic and a light summer 
W. R. Halliday, The Growth of the City State, 191

cloak (Theophrastus XII).

181. Plato, Charmides isgb. Cf. Athenaeus I, 21, 38.

182. "Quick, father, get them on; and then move forward Thus : in an opulent swaggering sort of way." (Wasps 1168.)

183. Aristotle, Ethics IV , 3, 11253. The Boor "talks in a loud voice" (Theophrastus XIV).

184. Demosthenes, in Pantaenetum 982, 52.

185. Demosthenes, de fals. Leg. 442, 314.

186. Aeschines, in Tim. 53, 59. F or forms of quail-fighting, see Pollux IX, 107. The sport of flipping a quail out of a marked circle is alluded to (Birds 1297); cock-fighting (Birds 759); horse racing (Birds 798 and Clouds, pass.) Enthusiasts often carried their birds about with them, cf. the story of the quail which Alcibiades carried under his cloak (Plutarch, Alcibiades 10). According to Plato carrying them about was thought to make them fit. In Laws VII, 789, he takes an illustration from "certain amusements which are carried to excess at Athens." "Not only boys, but often older persons, are in the habit of keeping quails and cocks, which they train to fight one another. And they are far from thinking that the contests in which they stir them up to fight with one another are sufficient exercise; for in addition to this, they carry them about - each having a big bird tucked in under his arms, and the smaller in his hands, and go for a walk of a great many miles for the sake of health, that is to say not their own health but the health of the birds." Solon in Lucian (Anacbarsis 37) claims on the other hand that cock fighting has an educational value for the citizen soldier owing to the example which it affords of unyiel ding courage. This is of course a familiar line of defence of the more brutalising forms of sport.

187. Plato, Lysis 211 . The same figure, in almost identical words, occurs in Socrates' mouth (Xen. Mem. I, vi, 14), a coincidence which suggests that it is an authentic saying of the historical Socrates.

188. See the orators passim.

189. Wasps 1269. Cf. Clouds 109. For the pheasant v. Phasian horse controversy, see Athenaeus IX, 37, 387a. Andocides pleads an alibi for 
W. R. Halliday, The Growth of the City State, 192

his father on the ground that he had been thrown and seriously hurt (Andocides, de Myst. 61).

190. Wasps 1220, 1301.

191. PH. "Yes how lie down?"

BDEL. "No, not in the least like that."

$\mathrm{PH}$. "How then?"

BDEL. "Extend your knee and let yourself

With practised ease subside along the cushions;

Then praise some piece of plate; inspect the ceiling;

Admire the woven hangings of the hall."

(Wasps 1210.)

192. Knights 415, 819.

193. Knights 357, Wasps 1216.

194. Knights 85, Wasps 525, Peace 300, Athenaeus XI, 73.

195. Knights 89, 349. Cf. Demosthenes, Philip. II, 30, 73. "They say that, being a water-drinker, I am naturally a cross-grained and ungenial fellow."

196. Knights 1187. Hesiod's farmer mixes in proportion of three to one (Works and Days 594). Athenaeus X, 426, 28, gives five to two.

197. Clouds 1355, Daitales, Frag. 223. The Surly Man "will not consent to sing or to recite or to dance" (Theophrastus III ). But Phei dippides' reason for refusal is not surliness. Evidently fashion was temporarily against it in young aristocratic circles. And among their elders the charms of after-dinner music had paled before the attractions of intellectual debate. "Then said Eryximachus, as you are all agreed that drinking is to be voluntary and that there is to be no compulsion, I move in the next place that the flute girl who has just made her appearance be told to go away : she may play to herself or, if she has a mind, to the women who are within. But on this day let us have conversation instead" (Plato, Symposium 1766).

198. Clouds 1361 foll.

199. Wasps 1202.

200. Wasps 1175 foll.

201. The Unseasonable Man, "when he is minded to dance, will seize 
W. R. Halliday, The Growth of the City State, 193

upon another person who is not yet drunk" (Theoph. IX). The Reckless Man is just the person to dance the cordax, sober and without a mask, in a comic chorus (Theoph. XVI).

202. Wasps 1478. A propos of Herodotus' story of Hippo-el ides, Athenaeus remarks, "in dancing and walking decorum and good order are honourableand disorder and vulgarity are discreditable" (XIV , 25). At the end of the same chapter he says "the dance is very nearly an armed exercise, and is a display, not only of good discipline in other respects, but also of the care which the dancers bestow on their persons." (Cf. Clouds 988.)

203. Plato, Symposium 212 foll. Later in the same evening, "Agathon arose in order that he might take his place on the couch by Socrates, when suddenly a band of revel lers entered and spoiled the order of the banquet. Someone who was going out having left the door open, they had found their way in and made themselves at home; great confusion ensued, and every one was compelled to drink large quantities of wine" (ib. 223).

204. Wasps 1387 foll. Cf. Geras, frag. 125, ap Athenaeus III, 74. For the concerted breaking-up of a gambling hell by young bloods, see Aeschines in Timarchum 59: "One night when they were drunk, they, with certain others, whose names I do not care to mention, burst into the house where Pittalacus was living. First they smashed the implements of his tradeand tossed them into thestreet - sundry dice and dice-boxes and his gaming utensils in general; they killed the quails and cocks, so well-beloved by the miserable man, and finally they led Pittalacus himself to the pillar and gave him an inhuman whipping which lasted until even the neighbours heard the uproar." In the fourth century there were clubs of "mohawks" calling themselves by such names as Ithyphalloi, Autolekythoi, or Triballi. Demosthenes, Conon, which is a speech for the prosecution in an assault and battery case, has furnished the material for Becker (Charikles, Scene V).

205. Birds 798, 1442.

206. Wasps 1355. 
W. R. Halliday, The Growth of the City State, 194

207. Peace 1208 foll.

208. Clouds 56, Wasps 252.

209. Clouds 6 foll. On the general conditions of Athens in war time, see Murray, Aristophanes and the War Party, p. 17. This has been reprinted in Essays and Addresses.

210. Plutarch, Alcibiadies 2.

211. See Plutarch, Alcibiades. The docking of the tail of a dog purchased for an extravagant sum, the unprovoked boxing on the ears of a respected citizen in public for a wager, the removal of part of his host's dining-room plate, are examples of the pranks by which the young Alcibiades advertised himself and earned thereputation of being what in the jargon of the Five Towns is called "a card."

212. In the introduction to one of his latest and poorest comedies, Mr. Shaw divides English Society before the war between Heartbreak House, the home of intellectual dilletantes, and Horseback Hall, the home of unintellectual sportsmen. The great original has been anticipated by Aristophanes, whose Clouds does much the same for Athens. The list given by the goddesses of the "Sophists" for whom they provide includes "imperialist prophets, doctors, drawing-room dilletantes, theatrical poets, and natural scientists" (II. 331 foll).

213. Plato, Republic561c. Versatility was themost striking characteristic of Alcibiades (Plutarch, Alc. 23, going back evidently to Satyrus, Athenaeus XII , 47), it is characteristic also of the new goddesses, the

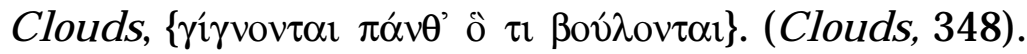

214. Plato, Republic 557c.

215. Gorgias 481 foll, and Plato passim. Cf. the Melian Dialogue, Thucyd. $\mathrm{V}, 85$ foll. Emphasis is laid in the Clouds upon the claims of the new rationalism in morals to be based upon the results of the scientific observation of Nature, not only in the opening scene in the Thinking Shop, but also in Pheidippides' arguments from the analogies of natural history.

216. Clouds 1476.

217. Clouds 1464. 